City of Aurora, Colorado Springs Utilities, Colorado Water Conservation Board, Lower Arkansas Valley Water Conservancy District, Pueblo Board of Water Works, Southeastern Colorado Water Activity Enterprise, Southeastern Colorado Water Conservancy District, Upper Arkansas Water Conservancy District

\title{
Occurrence and Distribution of Dissolved Solids, Selenium, and Uranium in Groundwater and Surface Water in the Arkansas River Basin from the Headwaters to Coolidge, Kansas, 1970-2009
}

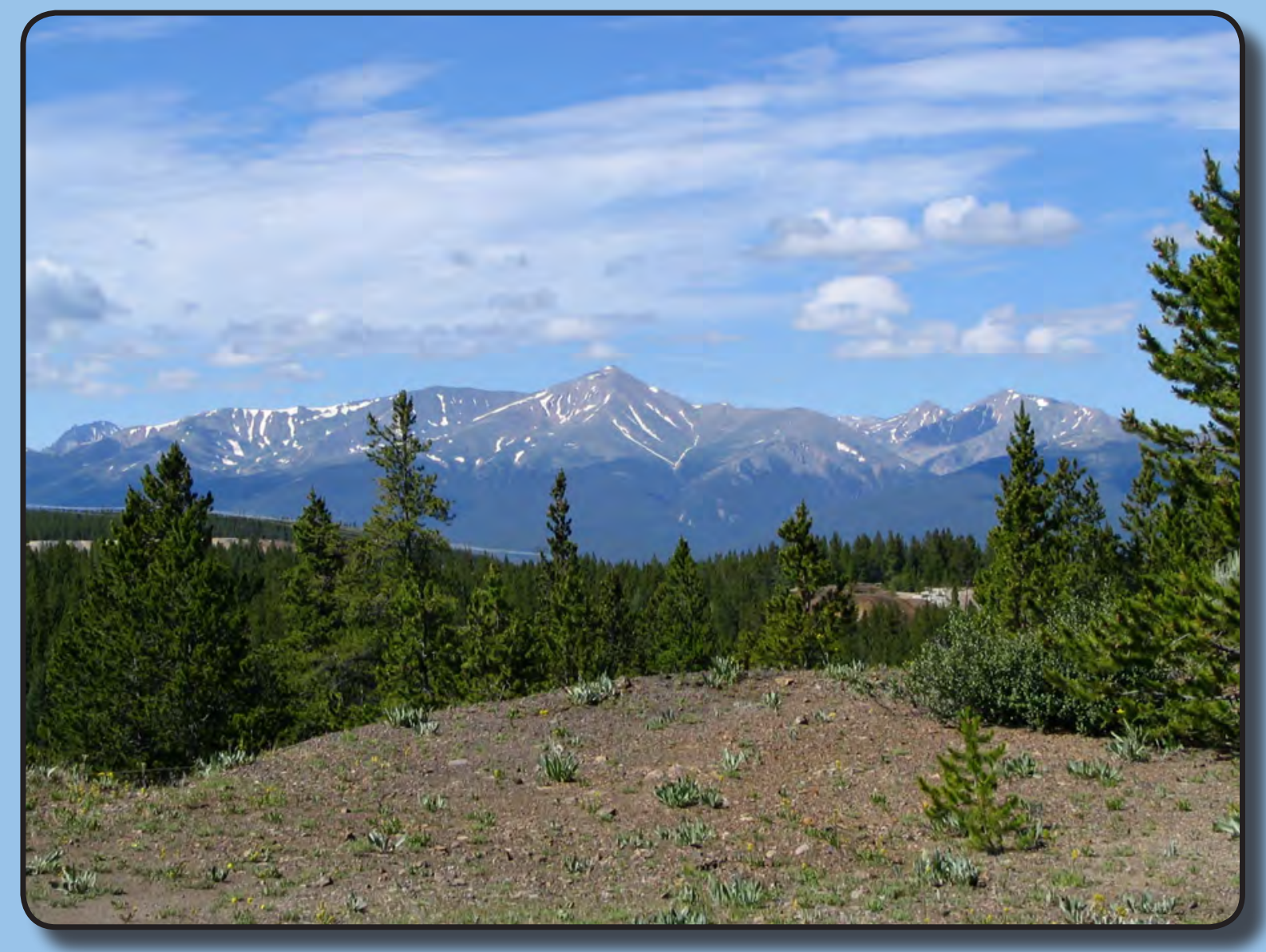

Scientific Investigations Report 2010-5069 
COVER:

Photo taken by Ken Watts near Leadville, Colorado. 


\section{Occurrence and Distribution of Dissolved Solids, Selenium, and Uranium in Groundwater and Surface Water in the Arkansas River Basin from the Headwaters to Coolidge, Kansas, 1970-2009}

By Lisa D. Miller, Kenneth R. Watts, Roderick F. Ortiz, and Tamara Ivahnenko

City of Aurora, Colorado Springs Utilities, Colorado Water Conservation Board, Lower Arkansas Valley Water Conservancy District, Pueblo Board of Water Works, Southeastern Colorado Water Activity Enterprise, Southeastern Colorado Water Conservancy District, Upper Arkansas Water Conservancy District

Scientific Investigations Report 2010-5069 


\title{
U.S. Department of the Interior \\ KEN SALAZAR, Secretary
}

\section{U.S. Geological Survey \\ Marcia K. McNutt, Director}

\author{
U.S. Geological Survey, Reston, Virginia: 2010
}

For more information on the USGS - the Federal source for science about the Earth, its natural and living resources, natural hazards, and the environment, visit http://www.usgs.gov or call 1-888-ASK-USGS

For an overview of USGS information products, including maps, imagery, and publications, visit http://www.usgs.gov/pubprod

To order this and other USGS information products, visit http://store.usgs.gov

Any use of trade, product, or firm names is for descriptive purposes only and does not imply endorsement by the U.S. Government.

Although this report is in the public domain, permission must be secured from the individual copyright owners to reproduce any copyrighted materials contained within this report.

Suggested citation:

Miller, L.D., Watts, K.R., Ortiz, R.F., and Ivahnenko, Tamara, 2010, Occurrence and distribution of dissolved solids, selenium, and uranium in groundwater and surface water in the Arkansas River Basin from the headwaters to Coolidge, Kansas, 1970-2009: U.S. Geological Survey Scientific Investigations Report 2010-5069, 59 p. 


\section{Contents}

Abstract

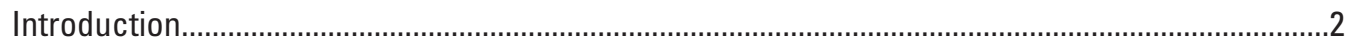

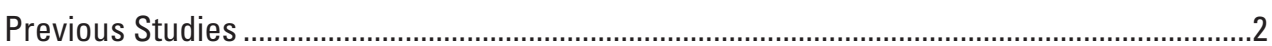

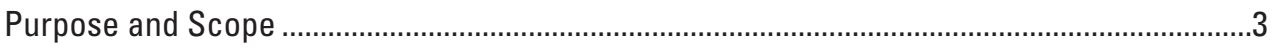

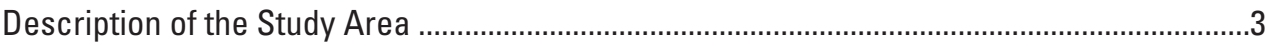

Hydrogeologic Setting ...............................................................................................

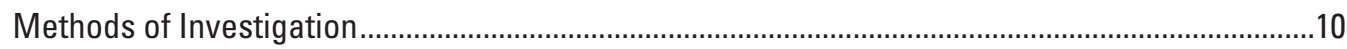

Classification of Hydrostratigraphic Units for Groundwater Sites .......................................10

Computation of Dissolved-Solids Concentrations................................................................10

Illustrations Used to Summarize and Display Spatial Variability of Constituent Concentrations ..............................................................................................11

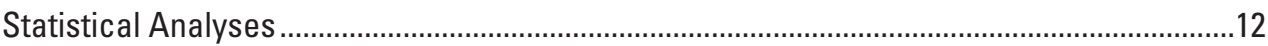

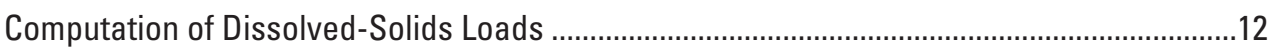

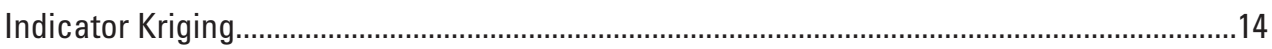

Quality Assurance and Quality Control ..................................................................................14

Occurrence and Distribution of Dissolved Solids, Selenium, and Uranium in Groundwater and Surface Water in the Arkansas River Basin from the Headwaters to Coolidge, Kansas .....................................................................14

Sources of Dissolved Solids in the Arkansas River Basin .................................................14

Sources of Selenium in the Arkansas River Basin.................................................................15

Sources of Uranium in the Arkansas River Basin .............................................................16

Groundwater and Surface-Water Data Used to Characterize the

Occurrence and Distribution of Dissolved Solids, Selenium, and Uranium in the Arkansas River Basin .................................................................16

Dissolved Solids and Specific Conductance in Groundwater in the

Arkansas River Basin ......................................................................................17

Temporal Variations in Specific-Conductance Values in Surface

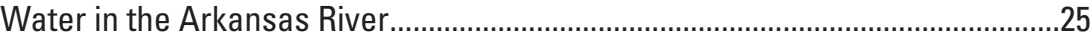

Dissolved Solids in Surface Water in the Arkansas River Basin from Granite, Colorado, to Coolidge, Kansas.........................................................25

Dissolved-Solids Concentrations and Loads in the Upper

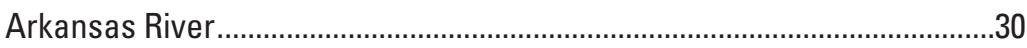

Dissolved-Solids Concentrations and Loads in the Arkansas River from Pueblo Reservoir to Avondale ..................................................30

Dissolved-Solids Concentrations and Loads in Fountain Creek ..............................32

Dissolved-Solids Concentrations and Loads in the Arkansas River from Avondale to Coolidge .................................................................32

Selenium in Groundwater in the Arkansas River Basin .............................................35

Selenium in Surface Water in the Arkansas River Basin.................................................35

Dissolved-Selenium Concentrations in the Upper Arkansas River .........................39

Dissolved-Selenium Concentrations and Instantaneous Loads in the Arkansas River from Pueblo Reservoir to Avondale .........................39

Dissolved-Selenium Concentrations and Instantaneous Loads in Fountain Creek 
Dissolved-Selenium Concentrations and Instantaneous Loads

in the Arkansas River from Avondale to Coolidge ........................................41

Dissolved Uranium in Groundwater in the Arkansas River Basin.............................43

Dissolved Uranium in Surface Water in the Arkansas River and Fountain Creek

Comparison of Dissolved Solids, Selenium, and Uranium Concentrations in

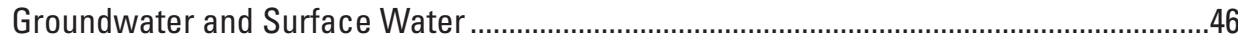

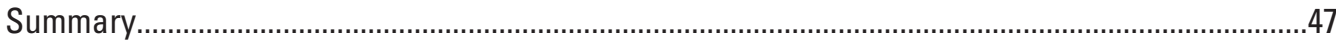

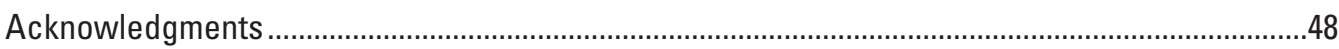

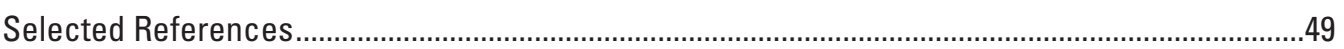

Appendix 1: Sources of Groundwater and Surface-Water Data Used in the Report.......................57

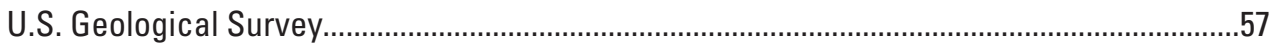

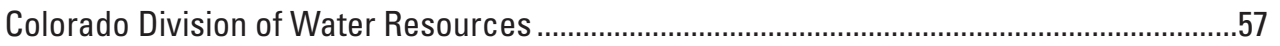

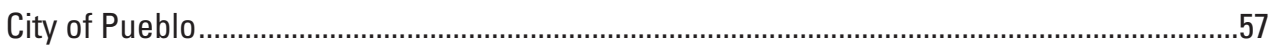

Colorado Department of Agriculture ................................................................................

Colorado State University - Fort Collins ……………….......................................................58

Colorado Department of Public Health and Environment .....................................................58

Appendix 2: Temporal Variations in Instantaneous Specific-Conductance Values

and Streamflow at Selected Surface-Water Sites in the Arkansas River

Basin, Colorado, 1960-2009

\section{Figures}

1. Location of the study area, surface-water-quality sites, and subbasins within the Arkansas River Basin...

2. (A) Physiographic provinces and (B) surface exposure of principal hydrostatigraphic units in the Arkansas River Basin, Colorado...

3. Estimated natural recharge in the Arkansas River Basin, Colorado.

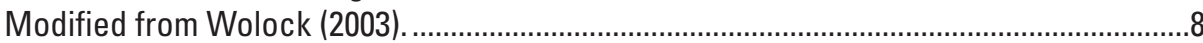

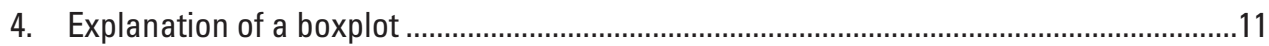

5. Locations of (A) City of Pueblo, Colorado Department of Agriculture, and Colorado State University Lower Arkansas River Valley Research,

(B) U.S. Geological Survey National Water Information System, and

(C) National Uranium Evaluation groundwater-quality sites (wells, springs, and test holes) with results for one or more selected water-quality characteristics, Arkansas River Basin, Colorado, August 1970 through August 2008

6. Median dissolved-solids concentration and specific-conductance values in groundwater by hydrostratigraphic unit and primary lithology, Arkansas River Basin, Colorado.

7. Boxplots showing variation in median concentrations of $(A)$ dissolved solids, (B) dissolved selenium, and (C) dissolved uranium in groundwater from unconsolidated Quaternary deposits (hydrostratigraphic unit 1 [HSU 1]) and from Upper Cretaceous shale and limestone (hydrostratigraphic unit 6 [HSU 6]), in the Arkansas River Basin, Colorado.

8. Variability in dissolved-solids concentrations in groundwater from unconsolidated Quaternary deposits (hydrostratigraphic unit 1) within 2 miles of the Arkansas River in Colorado. 
9. Median dissolved-solids concentrations in (A) unconsolidated Quaternary deposits (hydrostratigraphic unit 1) and (B) Upper Cretaceous shale and limestone (hydrostratigraphic unit 6) in the Arkansas River Basin, Colorado

10. Temporal variation in instantaneous $(\mathrm{A}-\mathrm{C})$ specific-conductance values and (D-F) streamflow at selected sites in the Arkansas River Basin, 1945-2008.

11. Spatial distribution of dissolved-solids concentrations in the Arkansas River from Granite, Colorado, to Coolidge, Kansas, 1976-2007.

12. (A) Average annual dissolved-solids concentration, (B) average annual dissolved-solids load, and $(C)$ average annual streamflow for irrigation (March-October) and nonirrigation (November-February) seasons at selected sites in the Arkansas River Basin, Colorado, 1995-2006

13. (A) Average annual dissolved-solids concentration, (B) average annual dissolved-solids load, and (C) average annual streamflow at selected sites in the Arkansas River from Granite, Colorado, to Coolidge, Kansas, 2000-2006.

14. Spatial distribution of specific conductance values at selected sites in Fountain Creek, Colorado, 1995-2007

15. Map showing sample site locations and simplified schematic of tributary inflows to and major canal diversions from the Arkansas River between Avondale and Las Animas, Colorado.

16. Summary of average annual dissolved-solids loads in tons per year at selected sites and percent load contribution for selected stream reaches in the Arkansas River Basin, 2000-2006.

17. Median dissolved-selenium concentrations in $(A)$ unconsolidated Quaternary deposits (hydrostratigraphic unit 1) and (B) Upper Cretaceous shale and limestone (hydrostratigraphic unit 6), Arkansas River Basin, Colorado, August 1970 through August 2008.

18. (A) Dissolved-selenium concentrations and (B) instantaneous dissolved-selenium loads at selected sites in the Arkansas River and tributaries from Pueblo Reservoir to Coolidge, Kansas, 1976-2007

19. (A) Dissolved-selenium concentrations and (B) instantaneous dissolvedselenium loads at selected sites in Fountain Creek, Colorado, 1995-2007.

20. Probability of concentrations of dissolved uranium greater than 30 micrograms per liter in groundwater, Arkansas River Basin, Colorado, August 1975-July 1979

21. (A) Dissolved-uranium concentrations, (B) instantaneous streamflows, and $(C)$ instantaneous dissolved-uranium loads at selected sites in the Arkansas River from Pueblo Reservoir to Las Animas, Colorado, 2005-2007 


\section{Tables}

1. Surface-water-quality site names and station names ....................................................

2. Hydrostratigraphic units and numbers of wells, springs, and test holes with water-quality analyses, Arkansas River Basin, Colorado, August 1970 through August 2008

3. Relations between specific-conductance values and dissolved-solids concentrations in surface water at selected sites in the Arkansas River Basin from Granite, Colorado, to Coolidge, Kansas, 1976-2007.

4. Data sources and numbers of groundwater sites and samples with concentrations of dissolved solids, dissolved selenium, dissolved uranium, and specific conductance values, Arkansas River Basin, Colorado, August 1970 through August 2008.

5. Summary of dissolved-solids, dissolved-selenium, and dissolved-uranium concentrations in surface-water samples at selected sites in the Arkansas River Basin, 1976-2007.

6. Summary of specific-conductance values and dissolved solids, dissolved selenium, and dissolved-uranium concentrations in surface-water samples at selected sites in Fountain Creek, Colorado, 1995-2007 


\section{Conversion Factors}

\section{SI to Inch/Pound}

\begin{tabular}{|c|c|c|}
\hline Multiply & By & To obtain \\
\hline \multicolumn{3}{|c|}{ Length } \\
\hline meter $(\mathrm{m})$ & 3.281 & foot $(\mathrm{ft})$ \\
\hline kilometer $(\mathrm{km})$ & 0.6214 & mile (mi) \\
\hline \multicolumn{3}{|c|}{ Area } \\
\hline square meter $\left(\mathrm{m}^{2}\right)$ & 0.0002471 & acre \\
\hline hectare (ha) & 2.471 & acre \\
\hline hectare (ha) & 0.003861 & square mile $\left(\mathrm{mi}^{2}\right)$ \\
\hline square kilometer $\left(\mathrm{km}^{2}\right)$ & 0.3861 & square mile $\left(\mathrm{mi}^{2}\right)$ \\
\hline \multicolumn{3}{|c|}{ Volume } \\
\hline liter $(\mathrm{L})$ & 0.2642 & gallon (gal) \\
\hline \multicolumn{3}{|c|}{ Flow rate } \\
\hline meter per day $(\mathrm{m} / \mathrm{d})$ & 3.281 & foot per day (ft/d) \\
\hline $\begin{array}{l}\text { cubic meter per second per square } \\
\text { kilometer }\left[\left(\mathrm{m}^{3} / \mathrm{s}\right) / \mathrm{km}^{2}\right]\end{array}$ & 91.49 & $\begin{array}{l}\text { cubic foot per second per square mile } \\
\qquad\left[\left(\mathrm{ft}^{3} / \mathrm{s}\right) / \mathrm{mi}^{2}\right]\end{array}$ \\
\hline \multicolumn{3}{|c|}{ Mass } \\
\hline milligram (g) & 0.00003527 & ounce, avoirdupois (oz) \\
\hline kilogram (kg) & 2.205 & pound avoirdupois (lb) \\
\hline \multicolumn{3}{|c|}{ Hydraulic conductivity } \\
\hline meter per day $(\mathrm{m} / \mathrm{d})$ & 3.281 & foot per day $(\mathrm{ft} / \mathrm{d})$ \\
\hline
\end{tabular}

\section{Inch/Pound to SI}

\begin{tabular}{lcc}
\hline \multicolumn{1}{c}{ Multiply } & \multicolumn{1}{c}{ Ly } & To obtain \\
\hline inch (in.) & 2.54 & \\
foot (ft) & 0.3048 & centimeter $(\mathrm{cm})$ \\
mile (mi) & 1.609 & meter $(\mathrm{m})$ \\
& \multicolumn{1}{c}{ Area } \\
kilometer $(\mathrm{km})$
\end{tabular}




\section{Conversion Factors-continued}

Inch/Pound to SI

\begin{tabular}{|c|c|c|}
\hline Multiply & By & To obtain \\
\hline \multicolumn{3}{|c|}{ Mass } \\
\hline ton per year (ton/yr) & 0.9072 & metric ton per year \\
\hline \multicolumn{3}{|c|}{ Radioactivity } \\
\hline picocurie per liter $(\mathrm{pCi} / \mathrm{L})$ & 0.037 & becquerel per liter $(\mathrm{Bq} / \mathrm{L})$ \\
\hline \multicolumn{3}{|c|}{ Specific capacity } \\
\hline $\begin{array}{l}\text { gallon per minute per foot } \\
[(\mathrm{gal} / \mathrm{min}) / \mathrm{ft})]\end{array}$ & 0.2070 & liter per second per meter $[(\mathrm{L} / \mathrm{s}) / \mathrm{m}]$ \\
\hline \multicolumn{3}{|c|}{ Hydraulic conductivity } \\
\hline foot per day (ft/d) & 0.3048 & meter per day $(\mathrm{m} / \mathrm{d})$ \\
\hline \multicolumn{3}{|c|}{ Hydraulic gradient } \\
\hline foot per mile (ft/mi) & 0.1894 & meter per kilometer $(\mathrm{m} / \mathrm{km})$ \\
\hline \multicolumn{3}{|c|}{ Transmissivity* } \\
\hline foot squared per day $\left(\mathrm{ft}^{2} / \mathrm{d}\right)$ & 0.09290 & meter squared per day $\left(\mathrm{m}^{2} / \mathrm{d}\right)$ \\
\hline
\end{tabular}

Temperature in degrees Celsius $\left({ }^{\circ} \mathrm{C}\right)$ may be converted to degrees Fahrenheit $\left({ }^{\circ} \mathrm{F}\right)$ as follows:

${ }^{\circ} \mathrm{F}=\left(1.8 x^{\circ} \mathrm{C}\right)+32$

Temperature in degrees Fahrenheit $\left({ }^{\circ} \mathrm{F}\right)$ may be converted to degrees Celsius $\left({ }^{\circ} \mathrm{C}\right)$ as follows:

${ }^{\circ} \mathrm{C}=\left({ }^{\circ} \mathrm{F}-32\right) / 1.8$

Vertical coordinate information is referenced to the North American Vertical Datum of 1988 (NAVD 88).

Horizontal coordinate information is referenced to the North American Datum of 1983 (NAD 83).

Altitude, as used in this report, refers to distance above the vertical datum.

Specific conductance is given in microsiemens per centimeter at 25 degrees Celsius $(\mu \mathrm{S} / \mathrm{cm}$ at $\left.25^{\circ} \mathrm{C}\right)$.

Concentrations of chemical constituents in water are given either in milligrams per liter (mg/L) or micrograms per liter ( $\mu \mathrm{g} / \mathrm{L})$. 


\section{Abbreviations Used in this Report}

\begin{tabular}{|c|c|}
\hline AMLE & Adjusted Maximum Likelihood Estimation \\
\hline $\mathrm{Ca}^{2+}$ & calcium \\
\hline CDA & Colorado Department of Agriculture \\
\hline CDWR & Colorado Division of Water Resources \\
\hline CDPHE & Colorado Department of Health and Environment \\
\hline CDSS & Colorado Decision Support System \\
\hline CERCLA & $\begin{array}{l}\text { Comprehensive Environmental Response, Compensation, } \\
\text { and Liability Act }\end{array}$ \\
\hline $\mathrm{Cl}^{-}$ & chloride \\
\hline CWOCC & Colorado Water Quality Control Commission \\
\hline CSUFC & Colorado State University - Fort Collins \\
\hline DS & dissolved solids \\
\hline FORTRAN & Formula Translation computer programming language \\
\hline $\mathrm{ft}^{3} / \mathrm{s}$ & cubic feet per second \\
\hline $\mathrm{HCO}_{3}^{-}$ & bicarbonate \\
\hline $\mathrm{HSU}^{3}$ & hydrostratigraphic unit \\
\hline IQR & interquartile range (IOR) \\
\hline $\mathrm{K}^{+}$ & potassium \\
\hline LAD & Least Absolute Deviation \\
\hline LARVR & Lower Arkansas River Valley Research \\
\hline LOADEST & Load Estimator Model \\
\hline LOWESS & Locally Weighted Scatterplot Smooth \\
\hline MCL & maximum contaminant level \\
\hline $\mathrm{meq} / \mathrm{L}$ & milliequivalents per liter \\
\hline $\mathrm{mg} / \mathrm{L}$ & milligram per liter \\
\hline$\mu \mathrm{g} / \mathrm{L}$ & microgram per liter \\
\hline$\mu \mathrm{S} / \mathrm{cm}$ & microsiemens per centimeter \\
\hline $\mathrm{Mg}^{2+}$ & magnesium \\
\hline MLE & Maximum Likelihood Estimation \\
\hline $\mathrm{Na}^{+}$ & sodium \\
\hline NWIS & USGS National Water Information System database \\
\hline $\mathrm{QA} / \mathrm{QC}$ & quality assurance and quality control \\
\hline$r^{2}$ & coefficient of determination \\
\hline RCRA & Resource Conservation and Recovery Act \\
\hline SC & specific conductance \\
\hline $\mathrm{SeO}_{3}^{-2}$ & selenite \\
\hline $\mathrm{SO}_{4}^{2-}$ & sulfate \\
\hline $\mathrm{SO}_{3}^{2-}$ & sulfite \\
\hline STORET & $\begin{array}{l}\text { U.S. Environmental Protection Agency's Storage and } \\
\text { Retrieval system }\end{array}$ \\
\hline t/d & tons per day \\
\hline$t / y r$ & tons per year \\
\hline USEPA & U.S. Environmental Protection Agency \\
\hline USGS & U.S. Geological Survey \\
\hline WWTF & waste water treatment facilities \\
\hline WWTP & waste water treatment plant \\
\hline
\end{tabular}





\title{
Occurrence and Distribution of Dissolved Solids, Selenium, and Uranium in Groundwater and Surface Water in the Arkansas River Basin from the Headwaters to Coolidge, Kansas, 1970-2009
}

\author{
By Lisa D. Miller, Kenneth Watts, Roderick F. Ortiz, and Tamara Ivahnenko
}

\begin{abstract}
In 2007, the U.S. Geological Survey (USGS), in cooperation with City of Aurora, Colorado Springs Utilities, Colorado Water Conservation Board, Lower Arkansas Valley Water Conservancy District, Pueblo Board of Water Works, Southeastern Colorado Water Activity Enterprise, Southeastern Colorado Water Conservancy District, and Upper Arkansas Water Conservancy District began a retrospective evaluation to characterize the occurrence and distribution of dissolvedsolids (DS), selenium, and uranium concentrations in groundwater and surface water in the Arkansas River Basin based on available water-quality data collected by several agencies. This report summarizes and characterizes available DS, dissolved-selenium, and dissolved-uranium concentrations in groundwater and surface water for 1970-2009 and describes DS, dissolved-selenium, and dissolved-uranium loads in surface water along the main-stem Arkansas River and selected tributary and diversion sites from the headwaters near Leadville, Colorado, to the USGS 07137500 Arkansas River near Coolidge, Kansas (Ark Coolidge), streamgage, a drainage area of 25,410 square miles.

Dissolved-solids concentrations varied spatially in groundwater and surface water in the Arkansas River Basin. Dissolved-solids concentrations in groundwater from Quaternary alluvial, glacial drift, and wind-laid deposits (HSU 1) increased downgradient with median values of about $220 \mathrm{mg} / \mathrm{L}$ in the Upper Arkansas subbasin (Arkansas River Basin from the headwaters to Pueblo Reservoir) to about $3,400 \mathrm{mg} / \mathrm{L}$ in the Lower Arkansas subbasin (Arkansas River Basin from John Martin Reservoir to Ark Coolidge). Dissolved-solids concentrations in the Arkansas River also increased substantially in the downstream direction between the USGS 07086000 Arkansas River at Granite, Colorado (Ark Granite), and Ark Coolidge streamgages. Based on periodic data collected from 1976-2007, median DS concentrations in the Arkansas River ranged from about $64 \mathrm{mg} / \mathrm{L}$ at Ark Granite to about 4,060 mg/L at Ark Coolidge representing over a 6,000 percent increase in median DS concentrations.
\end{abstract}

Temporal variations in specific conductance values (which are directly related to DS concentrations) and seasonal variations in DS concentrations and loads were investigated at selected sites in the Arkansas River from Ark Granite to Ark Coolidge. Analyses indicated that, for the most part, specific conductance values (surrogate for DS concentrations) have remained relatively constant or have decreased in the Arkansas River since about 1970. Dissolved-solids concentrations in the Arkansas River were higher during the nonirrigation season (November-February) than during the irrigation season (March-October). Average annual DS loads, however, were higher during the irrigation season than during the nonirrigation season. Average annual DS loads during the irrigation season were at least two times and as much as 23 times higher than average annual DS loads during the nonirrigation season with the largest differences occurring at sites located downstream from the two main-stem reservoirs at USGS 07099400 Arkansas River above Pueblo, Colorado (Ark Pueblo), (which is below Pueblo Reservoir) and USGS 07130500 Arkansas River below John Martin Reservoir, Colorado (Ark below JMR).

From January 2000 through December 2006, average annual DS loads in the Arkansas River ranged from about 18,000 tons per year (t/yr) at Ark Granite to about 303,500 t/yr at the USGS 07109500 Arkansas River near Avondale, Colorado (Ark Avondale), streamgage to about 363,800 t/yr at Ark below JMR to about 458,400 t/yr at Ark Coolidge (includes estimated DS load for Frontier Ditch). During this period, about 83 percent of the average annual DS load at Ark below JMR and about 66 percent of the average annual DS load at Ark Coolidge can be attributed to sources upstream from Ark Avondale.

The concentration of dissolved selenium (August 1970August 2008) in groundwater samples used in the analysis ranged from less than 1 microgram per liter $(\mu \mathrm{g} / \mathrm{L})$ to more than 3,700 $\mu \mathrm{g} / \mathrm{L}$. Concentrations of dissolved selenium in groundwater from unconsolidated Quaternary deposits increased downgradient from median values of about $5 \mu \mathrm{g} / \mathrm{L}$ in the Upper Arkansas and Fountain Creek subbasins to 
$16.2 \mu \mathrm{g} / \mathrm{L}$ and $14.8 \mu \mathrm{g} / \mathrm{L}$ in the Middle Arkansas (Arkansas River Basin between Pueblo Reservoir and John Martin Reservoir) and Lower Arkansas subbasins, respectively.

The largest percent increases in dissolved-selenium concentrations between sites in the Arkansas River occurred between USGS 07097000 Arkansas River at Portland, Colorado (Ark Portland), and Ark Pueblo and Ark Pueblo and USGS 07099970 Arkansas River at Moffat Street at Pueblo, Colorado (Ark Moffat St). Unlike DS concentrations, dissolved-selenium concentrations and the variability in dissolved-selenium concentrations did not increase substantially in the Arkansas River between Ark Avondale and USGS 07124000 Arkansas River at Las Animas, Colorado (Ark Las Animas). The highest instantaneous dissolved-selenium loads in the Arkansas River were measured in the reach downstream from the confluence with Fountain Creek to Ark Avondale. Instantaneous dissolved-selenium loads in the Arkansas River decreased between Ark Avondale and USGS 07119700 Arkansas River at Catlin Dam near Fowler, Colorado (Ark Catlin Dam), and then remained relatively constant in the river to Ark Coolidge.

Concentrations of dissolved uranium (August 1970August 2008) in groundwater varied over about 5 orders of magnitude from unconsolidated Quaternary deposits and Upper Cretaceous shale and limestone in the Arkansas River Basin in Colorado. Probabilities of exceeding $30 \mu \mathrm{g} / \mathrm{L}$ of dissolved uranium in groundwater were greatest in Otero, Kiowa, Cheyenne, and Prowers counties, where probabilities commonly ranged from 30 to 60 percent. These areas coincide with areas in which the lower part of the Pierre Shale and upper part of the Niobrara Formation (suspected sources of uranium) crop out or are directly overlain by the unconsolidated Quaternary deposits.

Dissolved-uranium concentrations and the variability in dissolved-uranium concentrations measured in the Arkansas River typically increased in the downstream direction. Based on data collected from 2005 through 2007, patterns in median instantaneous dissolved-uranium loads resembled patterns in median instantaneous streamflows in the Arkansas River between Ark Pueblo and the USGS 07120500 Arkansas River near Rocky Ford, Colorado (Ark Rocky Ford), streamgage. Downstream from Ark Rocky Ford, median instantaneous streamflows decreased; whereas, median instantaneous-dissolved-uranium loads remained constant or increased.

\section{Introduction}

Water in the Arkansas River Basin is a valuable resource used for agricultural, municipal, recreational, power production, industrial, livestock, domestic, and mining purposes. Changes in water storage, water releases, and(or) transfer of water within or outside of the Arkansas River Basin are likely to occur to accommodate the growing population. These water-use changes have the potential to affect water quality within the basin by affecting such things as the dilution of chemicals and sediment transport. In addition to changes in water use, land-use changes associated with urbanization and agricultural practices also may affect water quality within the basin. Urbanization and agricultural practices can increase contaminant loading to groundwater and surface water and change groundwater recharge and streamflow characteristics. As the result of continuing water-quality concerns and recognition of the importance of understanding potential effects of changes in land and water uses throughout the Arkansas River Basin, the U.S. Geological Survey (USGS), in cooperation with the City of Aurora, Colorado Springs Utilities, Colorado Water Conservation Board, Lower Arkansas Valley Water Conservancy District, Pueblo Board of Water Works, Southeastern Colorado Water Activity Enterprise, Southeastern Colorado Water Conservancy District, and Upper Arkansas Water Conservancy District, began a comprehensive basin-wide strategy to address multiple water-quality concerns. As part of this effort, water-quality issues within the basin were identified and prioritized by stakeholders. The occurrence of high concentrations of dissolved solids (DS), selenium, and uranium in groundwater and surface water affecting agricultural productivity, in-stream water quality and(or) drinking-water quality in selected parts of the basin was identified as a priority waterquality concern by stakeholders. To begin to address this concern, available groundwater- and surface-water-quality data were compiled to characterize the occurrence and distribution of DS, dissolved-selenium, and dissolved-uranium concentrations throughout the Arkansas River Basin.

\section{Previous Studies}

Groundwater and surface-water quality in the Arkansas River Basin have been analyzed previously by numerous investigators. Although there are no known investigations or reports that describe basin-wide groundwater quality for the Arkansas River Basin in Colorado, several reports describe groundwater quality for major parts of principal aquifers in the study area. One of the first investigations of groundwater in the Arkansas River Basin in Colorado (Darton, 1906) presented results of chemical analyses of groundwater from wells completed in the Dakota Sandstone. Crouch and others (1984) reported DS concentrations in groundwater from alluvial, basin-fill, and bedrock aquifers in the Arkansas River Basin upstream from Pueblo, including southwestern Pueblo County. Robson and Banta (1987) described the quality of groundwater in the deep bedrock aquifers in eastern Colorado, including the Laramie-Fox Hills, Fort Hays-Codell, Dakota-Purgatoire, Entrada-Dockum, Lyons, and Fountain aquifers.

In 1993, a comprehensive 3-year surface-water-quality data-collection program was completed in the Arkansas River Basin in Colorado (Dash and Ortiz, 1996). An assessment of the surface-water quality in the basin was done using the data and included analysis of DS, major ions, trace elements, nutrients, radio-chemical constituents, pesticides, suspended 
sediment, and bacteria (Ortiz and others, 1998). Gaydos (1980), Abbott (1985), Cain (1985 and 1987), and Mueller and others (1991) described the quality of the Arkansas River including quality of irrigation-return flows, relations to specific conductance (SC), and operation of water systems. Miles (1977) focused on the downstream increase in salinity in the Arkansas River. Cain and Edelmann (1980) and Cain and others (1980a) investigated the effects of municipal and industrial wastewater discharges to the Arkansas River near Pueblo. Mau and others (2007) characterized water-quality and suspended-sediment conditions in the Monument and Fountain Creek watersheds for different flow regimes using data collected from 1981 through 2006. Various publications documenting ongoing research by Colorado State University-Fort Collins (CSUFC) (2009b) in the lower Arkansas River Basin are listed at http:// www.csuarkriver.colostate.edu/publications.html. Other reports of county or local extent that include data and discussions of groundwater and surface-water quality in the Arkansas River Basin of southeastern Colorado are included in the 'Selected References' at the end of this report, and others are listed in Kuzmiak and Strickland (1994).

\section{Purpose and Scope}

The purpose of this report is to (1) summarize and characterize available DS, dissolved-selenium, and dissolveduranium concentration data in groundwater and surface water in the Arkansas River Basin and (2) describe DS, dissolvedselenium, and dissolved-uranium loads in surface water along the main-stem Arkansas River and selected tributary and diversion sites from the USGS 07081200 Arkansas River near Leadville, Colorado (Ark Leadville), streamgage to the USGS 07137500 Arkansas River near Coolidge, Kansas (Ark Coolidge), streamgage (fig. 1), a drainage area of 25,410 square miles. This report uses existing groundwater and surface-water data collected from 1970 through 2009 and analyzed by the USGS, Colorado Division of Water Resources (CDWR), City of Pueblo, Colorado Department of Agriculture (CDA), Colorado State University at Fort Collins (CSUFC), and Colorado Department of Public Health and Environment (CDPHE).

Groundwater-quality data collected from August 1970 through August 2008 were used to characterize and describe the spatial distribution of specific conductance (SC) values and DS, dissolved-selenium, and dissolved-uranium concentrations throughout the Arkansas River Basin in Colorado. Surface-water-quality and instantaneous-streamflow data collected from January 1, 1976, through September 30, 2007, were compared spatially to develop downstream profiles and compute instantaneous dissolved-selenium and dissolved-uranium loads at selected surface-water sites along the main-stem Arkansas River and selected tributaries. Temporal trends in SC values were evaluated at selected Arkansas River sites using available data: SC values typically were available starting between 1960 and 1975 to present (July, 2009) at these sites.
Instantaneous water-quality data used in this report are available at http://rmgsc.cr.usgs.gov/cwqdr/Arkansas/ (accessed July 7, 2009). Table 1 shows surface-water-quality site names (used in this report) and station names. Daily SC, streamflow, and diversion data collected from January 1, 1995, through December 31, 2006, were used to compute DS loads along the main-stem Arkansas River and Fountain Creek. Daily SC and streamflow data are available at http://waterdata.usgs. gov $/ n w i s / d v ?$ referred_module $=$ sw\&search_criteria $=$ search site_no\&search_criteria $=$ site_tp_cd\&submitted_

form=introduction (accessed July 7, 2009). To retrieve the daily SC and streamflow data, enter the USGS site number, select "Streamflow, $\mathrm{ft}^{3} / \mathrm{s}$ " and "Specific conductance, water, unfiltered, $\mu \mathrm{S} / \mathrm{cm}$ at $25^{\circ} \mathrm{C}$," choose dates for data retrieval and output option, and press "Submit." Daily diversion data can be retrieved at http://cdss.state.co.us/DNN/StructuresDiversions/ tabid/75/Default.aspx (accessed July 7, 2009).

\section{Description of the Study Area}

The Arkansas River originates among some of the highest peaks in the continental United States, flowing from the high mountain basins onto the plains of southeastern Colorado. The Arkansas River Basin in Colorado lies within the Southern Rocky Mountains section of the Rocky Mountains physiographic province and the Colorado Piedmont and Raton sections of the Great Plains province (Fenneman and Johnson, 1946) (fig. 2A). The High Plains section of the Great Plains province lies along the eastern side of the basin. Upstream from Cañon City, the Arkansas River is characterized by steep gradient, high velocity flows that are confined to a relatively narrow rock and cobble stream channel. Downstream from Cañon City the river gradient decreases as the river flows out of the mountains onto the plains. Fountain Creek, a major tributary in the study area, flows into the Arkansas River within the city limits of Pueblo. Downstream from Fountain Creek, the river channel is a shifting sand channel that meanders along the alluvial flood plain.

The semiarid climate of the study area is characterized by low to moderate precipitation, substantial evaporation, low humidity, moderate to intense winds, and a large daily range in temperature. The mean annual precipitation in the study area ranges from about 10 inches in parts of the eastern plains to more than 40 inches at the crests of the highest mountains (Abbott, 1985; Pinyon Ecology Research Group, 2007). Prior to the advent of irrigated agriculture in the Arkansas River Basin during the 19th century, groundwater recharge in the basin occurred primarily from infiltration of precipitation through the unsaturated zone and from infiltration of surface water from losing streams. Because the area's climate is semiarid, the potential for natural recharge from precipitation likely is a small percentage of the average annual precipitation, particularly in the Great Plains part of the basin (fig. 2A). Wolock (2003a) estimated that natural recharge in the Arkansas River Basin varies from $0.08 \mathrm{in} / \mathrm{yr}$ near the southeastern corner of 


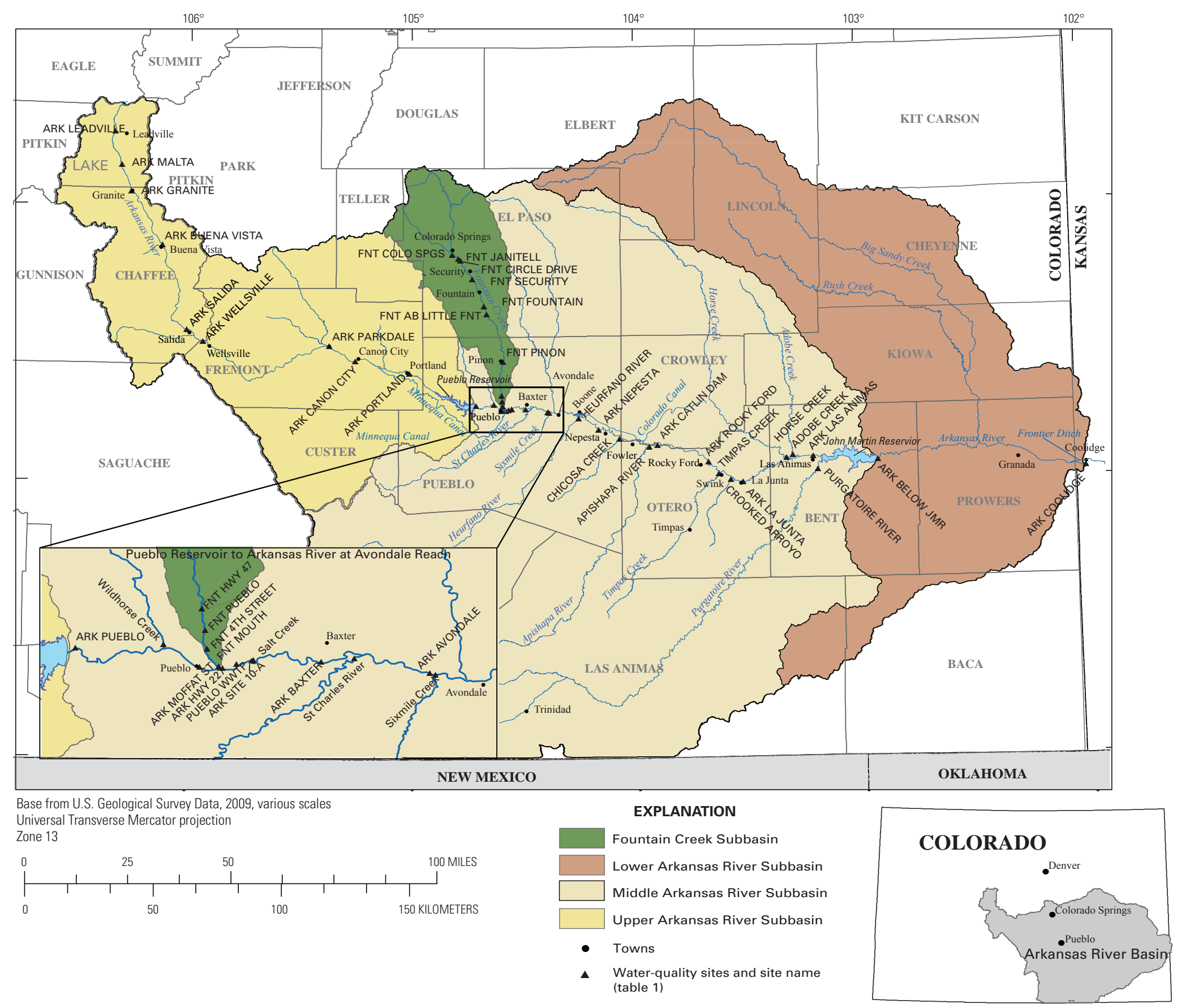

Figure 1. Location of the study area, surface-water-quality sites, and subbasins within the Arkansas River Basin. 
Table 1. Surface-water-quality site names and station names for the Arkansas River Basin.

[USGS, U.S. Geological Survey; CDPHE, Colorado Department of Health and Environment; Site names are presented in alphabetical order for ease of use]

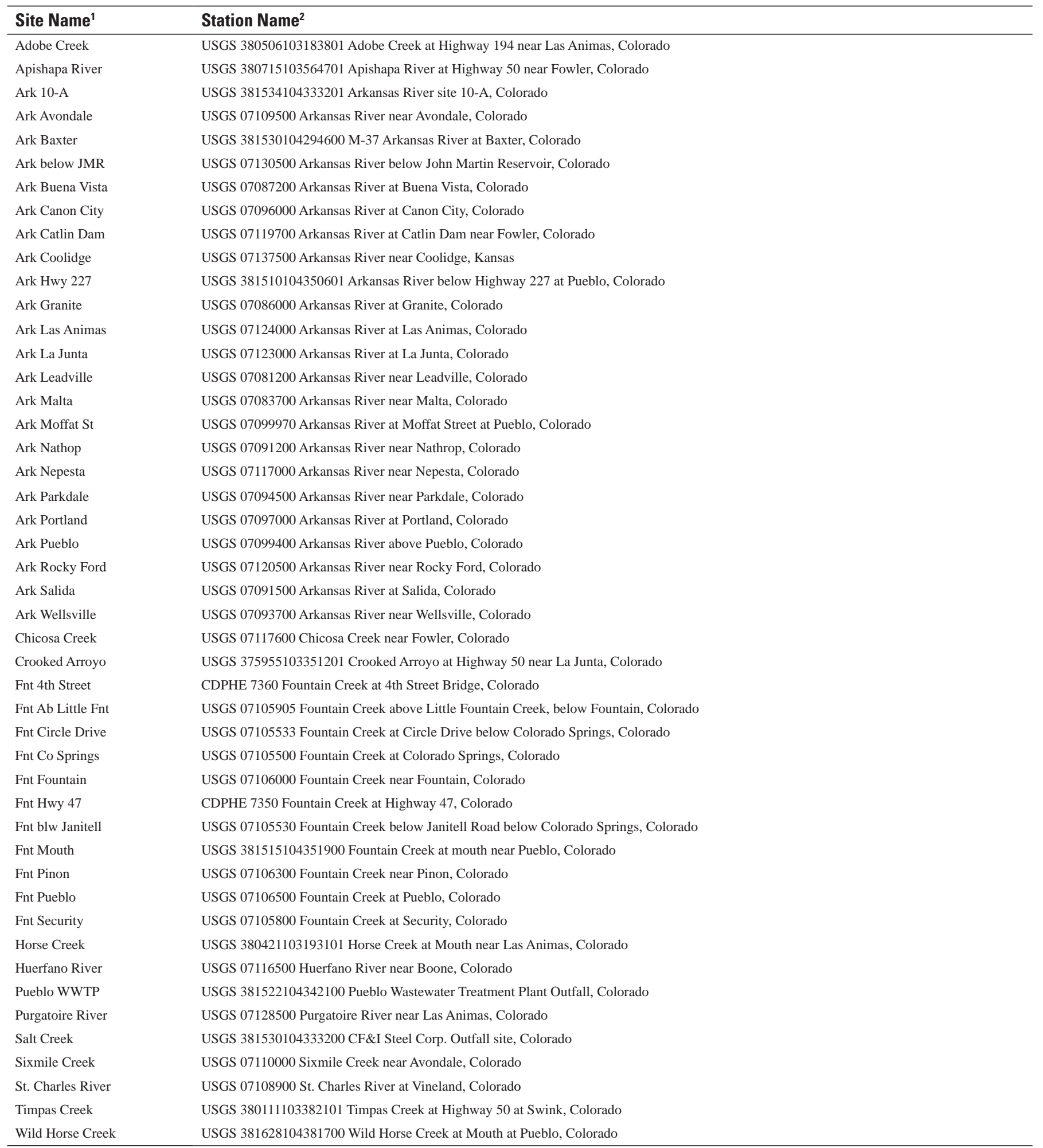

${ }^{1}$ Site names are abbreviated station names used in the report.

${ }^{2}$ Abbreviation at the beginning of the station name indicates which agency operates the site. 

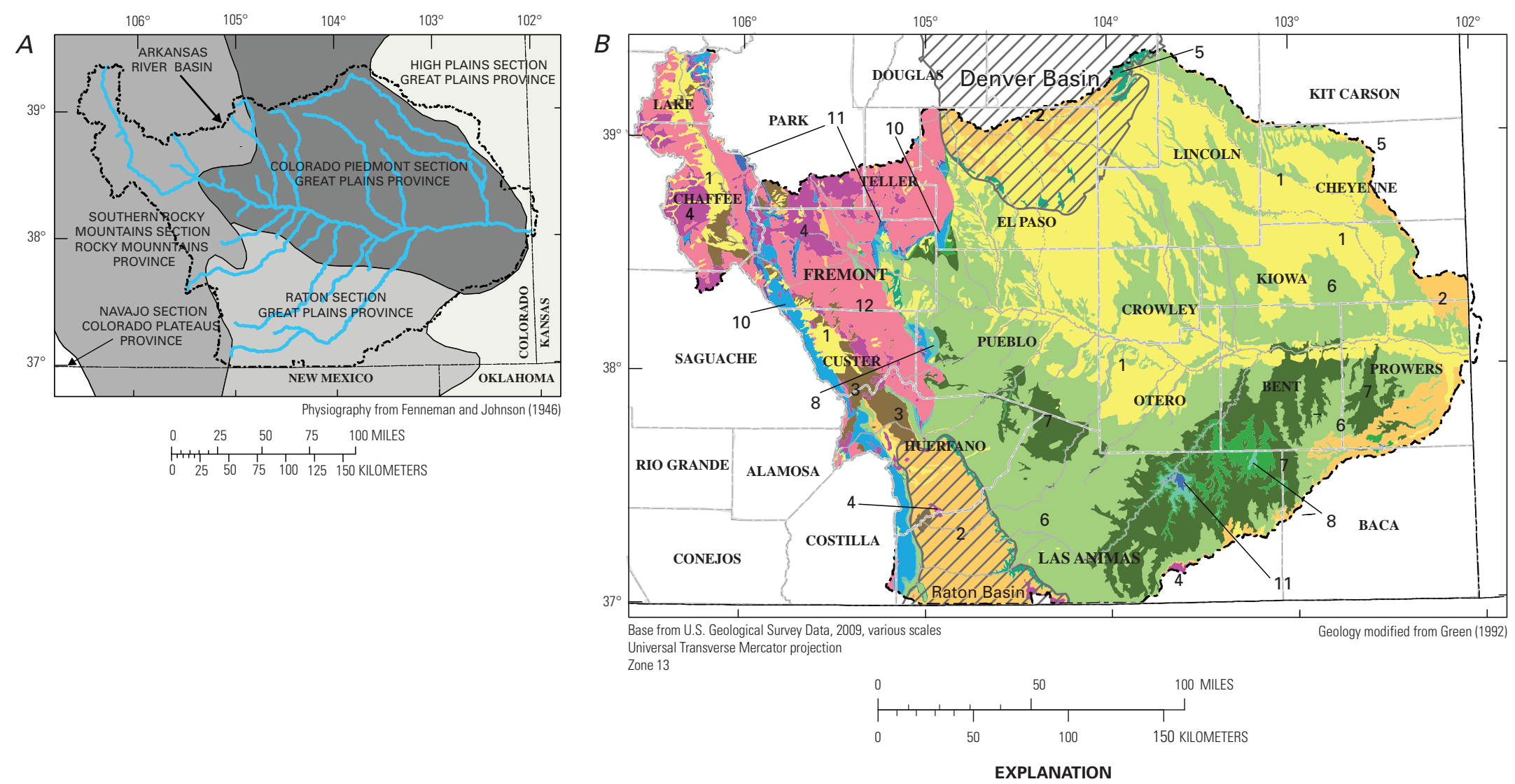

Figure 2. (A) Physiographic provinces and (B) surface exposure of principal hydrostatigraphic units in the Arkansas River Basin, Colorado.
Hydrostratigraphic unit number and description

$\square 1$ - Quaternary alluvial, glacial drift, and

$\square 2$ - Tertiary sandstone and conglomerate

- Tertiary siltstone, mudstone, shale,

4 - Tertian

5 - Upper Cretaceous sandstone, shale, and coal

$\square$ 6-Upper Cretaceous shale and limestone

7 - Lower Cretaceous sandstone and shale

- Jurassic-Triassic sandstone and

conglomerate

Jurassic-Trias
siltstone

10 - Paleozoic sandstone and conglomerate

11 - Paleozoic shale, limestone, and dolomite

- Cambrian and Precambrian igneous and metamorphic rocks

Regional structural and groundwater basin

-.- Arkansas river basin 
the study area to $17.5 \mathrm{in} / \mathrm{yr}$ along the crests of the mountains in Lake County (fig. 3).

By the mid-1880s, the waters of the Arkansas River and its tributaries were fully appropriated (all surface water claimed by water rights) for normal or average years (Abbott, 1985), and in areas in which surface water was diverted for irrigation, infiltration of irrigation water from canals and fields became a primary source of groundwater recharge. In 2003, the estimated irrigated area in the Arkansas River Valley between Pueblo and the Colorado-Kansas State line was about 316,978 acres, of which 102,381 acres was fallow (Colorado Decision Support System, 2008).

Streamflow in the Arkansas River exhibits considerable seasonal variability with the majority of the total annual streamflow resulting from snowmelt runoff in the Rocky Mountains at the western boundary of the study area. Pueblo Reservoir near Pueblo (fig. 1) is the first main-stem reservoir on the Arkansas River and controls the release of stored water to the predominantly agricultural river valley downstream. Water is stored in Pueblo Reservoir under numerous programs for a variety of reasons (flood control, irrigation, public water supply, and others). The Winter-Water Storage Program seems to effect streamflow in the Arkansas River between Pueblo Reservoir and John Martin Reservoir more than the other programs. Under the Winter-Water Storage Program, water is stored in Pueblo Reservoir from November 15 to March 15 of each year (Southeastern Colorado Water Conservancy District, 2010). The program allows downstream irrigation-canal companies to store their direct-flow water in the reservoir for release in the spring or late summer when streamflow in the river may not be sufficient for irrigation needs. For nearly 120 miles downstream from Pueblo Reservoir, water from the river is diverted through a network of irrigation canals and applied and reapplied to grow crops in the valley. Ultimately, the river flows into John Martin Reservoir near Las Animas which, in turn, regulates the streamflow for downstream uses. Storage decreases substantially in both reservoirs by the end of the growing season because of decreased inflow and large downstream demands for irrigation water.

Most of the towns and cities in the Arkansas River Basin are located along the river corridor. Pueblo is the largest population center on the main stem of the Arkansas River with a population of more than 103,000 people. Colorado Springs, with a population of more than 372,000 people, is the largest city within the study area and is located 40 miles north of Pueblo on Fountain Creek in El Paso County. El Paso County, the most populated county within the study area, has a population of more than 596,000 people (http://quickfacts.census. gov/qfd/states/08/0816000.html, accessed July 1, 2009).

\section{Hydrogeologic Setting}

The diverse suite of rocks in the Arkansas River Basin includes Precambrian granites and metamorphic rocks; Paleozoic, Mesozoic (Cretaceous, Jurassic, and Triassic), and
Cenozoic (Tertiary) sedimentary rocks; Tertiary extrusive and intrusive igneous and volcaniclastic rocks; and unconsolidated Quaternary alluvial, wind-laid sand or silt, and glacial (drift) deposits (fig. 2B). The principal confining unit in the Great Plains portion of the Arkansas River Basin in Colorado consists of a thick sequence of Upper Cretaceous shale and limestone, which Jorgensen and others (1996) referred to as the Great Plains confining system. The Great Plains confining system was removed by erosion in an area along and southeast of the Purgatoire River valley from about 20 miles east of Trinidad, Colorado, to the confluence of the Purgatoire River with the Arkansas River at John Martin Reservoir (figs. 1 and 2B).

For purposes of discussion, the Arkansas River Basin was divided into four subbasins in this report as shown in figure 1. The first subbasin (Upper Arkansas) extends from the headwaters of the Arkansas River to Pueblo Reservoir, the second subbasin from Pueblo Reservoir to John Martin Reservoir (Middle Arkansas), the third subbasin (Fountain Creek) includes Fountain Creek from the headwaters to the confluence with the Arkansas River, and the final subbasin (Lower Arkansas) extends from John Martin Reservoir to Ark Coolidge (fig. 1).

The principal water-bearing hydrostratigraphic units (aquifers) in the Arkansas River Basin in Colorado include valley-fill aquifers, along the Arkansas River and Fountain Creek valleys; upland-alluvial aquifers, north of the Arkansas River in the Colorado Piedmont section; basin-fill aquifers in faulted basins in Chaffee, Custer, and Lake Counties; the Denver Basin aquifers; the Raton Basin aquifers; and the Dakota-Purgatoire aquifer (Topper and others, 2003). The Dakota-Purgatoire aquifer also is referred to as the DakotaCheyenne aquifer (Robson and Banta, 1987) and as the Maha and Apishapa aquifers (Jorgensen and others, 1996). Other Mesozoic and Paleozoic sedimentary rocks, and Tertiary igneous, and Cambrian and Precambrian igneous and metamorphic rocks locally are important aquifers but generally few hydrologic and water-quality data are available for them. Table 2 presents the gross lithologic characteristics of the timestratigraphic units and definitions of the hydrostratigraphic units used in this report to classify sources of groundwater to wells and springs, and lists the numbers of wells, springs, and test holes with water-quality data, considered in this report, by hydrostratigraphic unit. The generalized geology, the distribution of hydrostratigraphic units, at the land surface (fig. 2B), is modified from the digital geologic map of Colorado (Green, 1992).

Hydrostratigraphic unit is defined as a body of rock with considerable lateral extent that acts as a reasonably distinct hydrologic system (Maxey, 1964). Hydrostratigraphic unit 1 (HSU 1) consists of Quaternary alluvial and wind-laid deposits (valley-fill and upland-alluvial aquifers) in the Middle and Lower Arkansas subbasins and includes Quaternary glacial deposits in the Upper Arkansas subbasin (figs. 1 and 2B). In the Upper Arkansas subbasin, in Chaffee, Custer, and Lake Counties, Quaternary alluvium along streams, alluvial-terrace and alluvial-fan deposits, and glacial outwash and till, overlie 


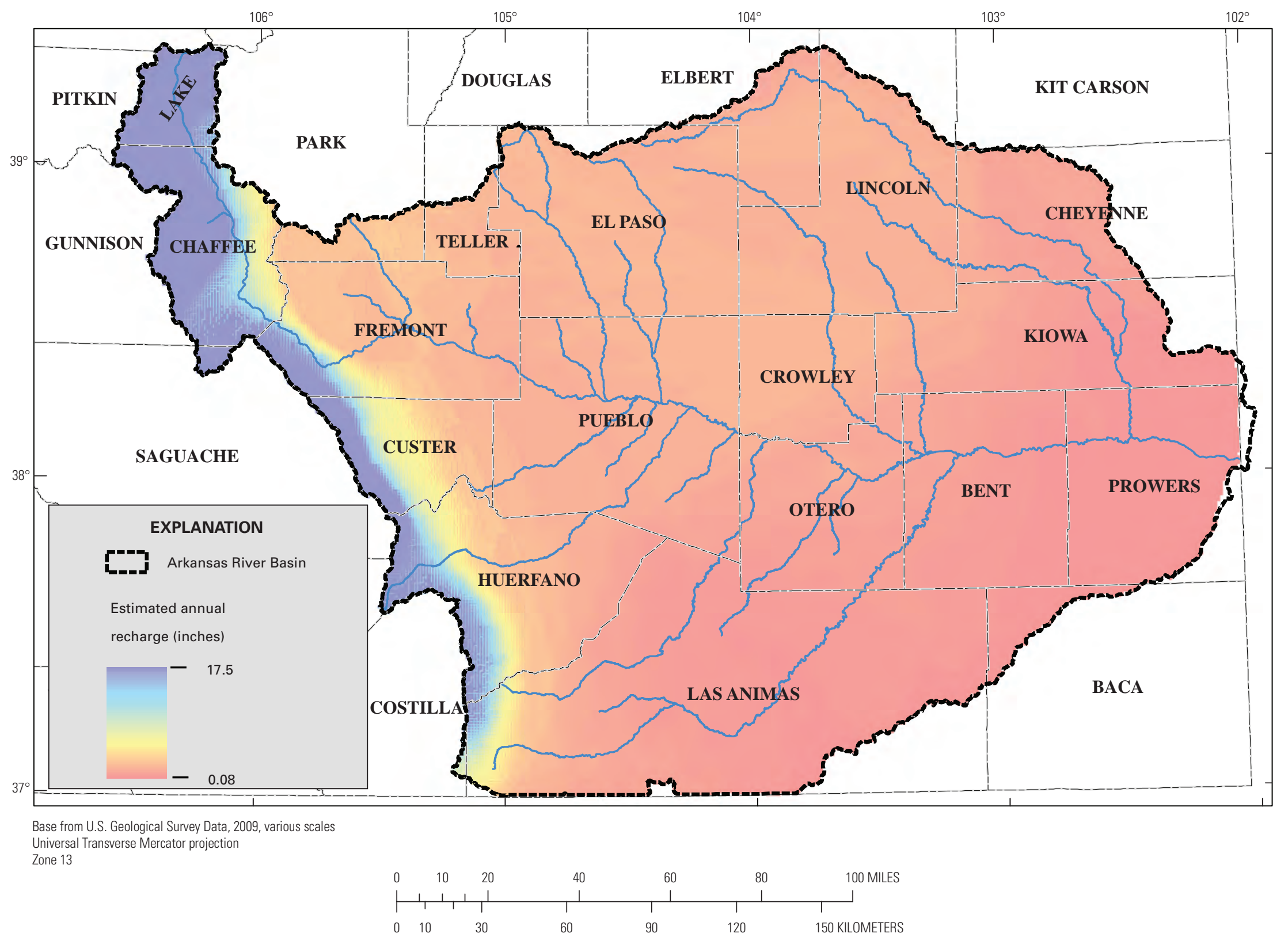

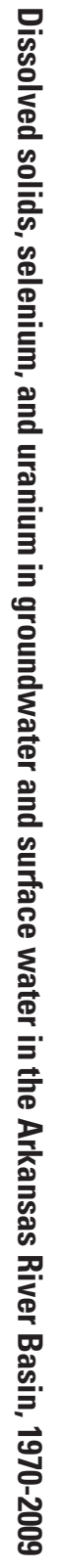

Figure 3. Estimated natural recharge in the Arkansas River Basin, Colorado. Modified from Wolock (2003). 
Table 2. Hydrostratigraphic units and numbers of wells, springs, and test holes with water-quality analyses, Arkansas River Basin, Colorado, August 1970 through August 2008.

[ ${ }^{1}$ Hydrostratigraphic unit numbers are used to indicate sources of groundwater samples for figures 6-9 and 17. ${ }^{2}$ Indicates an aquifer that includes strata spans the Tertiary-Cretaceous time-stratigrphic boundary.]

\begin{tabular}{|c|c|c|c|c|c|c|}
\hline Time-stratigraphic unit & $\begin{array}{l}\text { Hydrostratigraphic units } \\
\text { (rock types) }\end{array}$ & $\begin{array}{l}\text { Hydrostratigraphic } \\
\text { unit number }\end{array}$ & Aquifers & Wells & Springs & Test holes \\
\hline Quaternary & $\begin{array}{l}\text { Unconsolidated alluvial, glacial } \\
\text { drift, and wind-laid deposits }\end{array}$ & 1 & Alluvial & 1,414 & 65 & 9 \\
\hline \multirow{3}{*}{ Tertiary } & Sandstone and conglomerate & 2 & Basin-fill & 320 & 68 & 3 \\
\hline & Siltstone, mudstone, shale, and coal & 3 & $\begin{array}{c}\text { Denver Basin -- Dawson, Denver, } \\
\text { and Arapaho²; and Raton Basin } \\
\text {-- Huerfano, Poison Canyon, and } \\
\text { Raton }^{2}\end{array}$ & 41 & 12 & 0 \\
\hline & Extrusive and intrusive igneous rocks & 4 & & 20 & 49 & 0 \\
\hline \multirow[t]{2}{*}{ Cretaceous, Upper } & Sandstone, shale, and coal & 5 & $\begin{array}{l}\text { Denver Basin -- Arapaho² and Lara- } \\
\text { mie-Fox Hills; and Raton Basin } \\
\text {-- Raton², Vermejo, and Trinidad }\end{array}$ & 100 & 4 & 3 \\
\hline & Shale and limestone & 6 & Fort Hays-Codell & 758 & 111 & 1 \\
\hline Cretaceous, Lower & Sandstone with shale & 7 & Dakota-Purgatoire & 400 & 101 & \\
\hline \multirow{2}{*}{ Jurassic-Triassic } & Sandstone and conglomerate & 8 & Entrada-Dockum & 9 & 2 & 0 \\
\hline & Mudstone, shale, and siltstone & 9 & & 62 & 19 & 0 \\
\hline \multirow{2}{*}{ Paleozoic, undifferentiated } & Sandstone and conglomerate & 10 & Lyons and Fountain & 13 & 25 & 0 \\
\hline & Shale, limestone, and dolomite & 11 & & 6 & 6 & 0 \\
\hline Cambrian and Precambrian & Igneous and metamorphic (crystalline) rocks & 12 & & 18 & 98 & 0 \\
\hline
\end{tabular}


Tertiary sedimentary rocks (HSU 3) that were deposited in the fault-controlled basins bounded by Precambrian crystalline rocks (HSU 12) and Paleozoic sedimentary rocks (HSU 11) (fig. 2B). In the Middle and Lower Arkansas subbasins, the valley floors of the Arkansas River and Fountain Creek are underlain by alluvium that was deposited in valleys that are eroded into Cretaceous shale (HSU 6), limestone (HSU 6), and sandstone (HSU 5). These valley-fill deposits consist of unconsolidated Quaternary stream alluvium and alluvialterrace deposits along the Arkansas River and Fountain Creek (figs. 1 and 2B). The upland-alluvial aquifers consist of unconsolidated Quaternary alluvial and alluvial-terrace deposits in upland areas and the wind-laid sands that commonly overlay them (fig. 2B). The alluvial and alluvial-terrace deposits in the valley-fill and upland-alluvial aquifers consist of mixtures of gravel, sand, silt, and clay that were eroded from the mountains and from sedimentary rocks within the Great Plains (fig. 2A and 2B). In the Colorado Piedmont section, 3-12 meters (about 10-40 feet) of wind-laid sand typically covers the upland alluvial deposits (Madole and others, 2005). Alluvial aquifers in the Raton section are limited in extent. Hurr and Moore (1972) and Nelson and others (1989a, 1989b, 1989c) present maps showing hydrogeologic characteristics of the Arkansas River valley-fill aquifer, downstream from Pueblo to the Colorado-Kansas State line. Radell and others (1994) present maps showing hydrogeologic characteristics of part of the Fountain Creek valley-fill aquifer between Colorado Springs and Fountain, Colo.

\section{Methods of Investigation}

Various data sets used in the analyses were obtained from the USGS, CDWR, City of Pueblo, CDA, CSUFC, and CDPHE. Before 1990, USGS water-quality data were collected and processed using standard USGS techniques and procedures (U.S. Geological Survey, 1977). Dash and Ortiz (1996) describe methods of data collection and analysis used to collect USGS water-quality data from 1990 through 1993; the same or similar methods and analysis described by Sylvester and others (1990) and Ward and Harr (1990) were used by the USGS to collect and process water-quality data in the Arkansas River Basin throughout the 1990s. Water-quality data collected by the USGS since 1999 were collected using procedures documented in the USGS National Field Manual (variously dated) and Wagner and others (2006). USGS waterquality samples were analyzed using procedures documented in Fishman and Friedman (1985), Faires (1993), Fishman (1993), Garbarino (1999), and Garbarino and others (2006). Descriptions of the type and quantity of data provided by or available from each agency and information on sampling protocols and quality assurance and quality control (QA/QC) protocols (if available) are provided in the Appendix 1 at the end of this report.

\section{Classification of Hydrostratigraphic Units for Groundwater Sites}

Identification of the source of a groundwater sample collected from a well or spring (the hydrostratigraphic unit from which the groundwater sample was collected) is useful in interpreting the quality of groundwater and in understanding groundwater flow paths. A generalized classification of hydrostratigraphic units (aquifers and confining units) based on generalized time-stratigraphic units from the digital geologic map of Colorado (Green, 1992) is used in this report. Because the aquifer or hydrostratigraphic unit was not reported for the majority of groundwater sites (wells, springs, and test holes), hydrostratigraphic units were estimated for 3,079 of the 3,737 groundwater sites, rather than disregard the water-quality data for those sites. The contributing hydrostratigraphic unit for a site was estimated, based on the well (or test hole) location and reported depth, the hydrostratigraphic units and depths of nearby wells, and hydrogeologic maps (Coffin and Horr, 1967; Hurr and Moore, 1972; Cain and others, 1980b; Robson and Romero, 1981; Robson and others, 1981a; and Robson and others, 1981b; Robson and Banta, 1987; Nelson and others, 1989a, 1989b, and 1989c; Radell and others, 1994; and Watts, 2006). The contributing hydrostratigraphic unit for a well with a reported depth was estimated by comparing its depth with the depths and associated aquifers of nearby wells or with depths estimated from geologic and hydrogeologic maps. When well depth and the aquifer were not reported, the contributing hydrostratigraphic unit was assumed to be the same as that of nearby wells or, if there were no nearby wells, the mapped geologic unit at the surface (fig. 2B). Springs without an identified source were assigned a hydrostratigraphic unit based on the spring location and the mapped geologic unit at the surface (fig. 2B).

\section{Computation of Dissolved-Solids Concentrations}

Most DS concentration data used in the analyses in this report were measured as residual on evaporation at 180 degrees Celsius. However, DS concentrations were not provided by CSUFC; therefore, DS concentrations were calculated as the sum of constituents for each sample (major cations and anions). Seven ions [bicarbonate $\left(\mathrm{HCO}_{3}^{-}\right)$, calcium $\left(\mathrm{Ca}^{2+}\right)$, chloride $\left(\mathrm{Cl}^{-}\right)$, magnesium $\left(\mathrm{Mg}^{2+}\right)$, potassium $\left(\mathrm{K}^{+}\right)$, sodium $\left(\mathrm{Na}^{+}\right)$, and sulfate $\left.\left(\mathrm{SO}_{4}{ }^{2-}\right)\right]$ make up about 95 percent of DS in groundwater (Runnells, 1993; Herczeg and Edmunds, 1999). An ion balance was done for quality-assurance purposes. Concentrations of the major cations and anions, in milligrams per liter (mg/L), were converted to values expressed in milliequivalents per liter (meq/L) using conversion factors from Hem (1985, table 9). If the difference between the sum of the cations and the sum of the anions was greater than 5 percent of the sum of the cations plus the sum of the anions divided by two, the DS concentration was not used in this analysis. 


\section{Illustrations Used to Summarize and Display Spatial Variability of Constituent Concentrations}

Boxplots, bar graphs, and maps are used in this report to depict the variability of selected water-quality characteristics. For groundwater, boxplots of constituent concentrations and SC values are presented to show the variability of quality within the basin and for selected categorical variables, such as geographic area and hydrostratigraphic unit. Bar graphs are used to show the spatial variability in concentrations. Maps are used to show the distribution of sites with selected water-quality characteristics, spatial variability in constituent concentrations, and the probability of dissolved-uranium concentrations greater than $30 \mu \mathrm{g} / \mathrm{L}$ (the maximum contaminant level for drinking water (U.S. Environmental Protection
Agency, 2003a)) in groundwater. Boxplots and bar graphs of concentrations, streamflow, and constituent loads are presented to show the spatial variability of these characteristics in surface water within the Arkansas River, Fountain Creek, and selected tributaries.

Boxplots were generated to show simple graphical summaries of selected data sets (that is constituent concentrations and constituent loads). An example of a boxplot is shown in figure 4. The upper horizontal line of the box is the 75th percentile or upper quartile (75 percent of the data are less than this value). The horizontal line within the box represents the median value (50 percent of the data are greater than this value and 50 percent of the data are less than this value). The lower horizontal line of the box is the 25th percentile or lower quartile (25 percent of the data are less than this value). The

Interquartile range (IQR)

(difference between 25th and 75th percentiles)

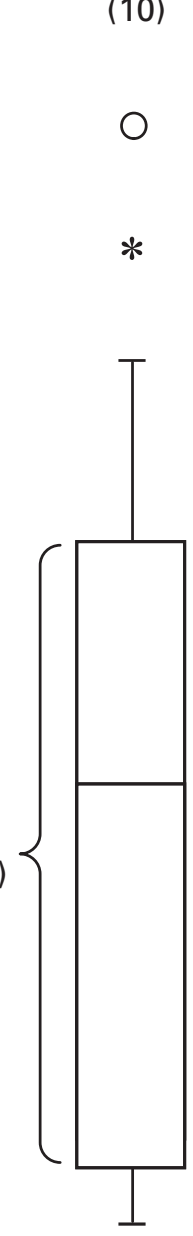

$\longleftarrow \quad$ Number of samples

Outlier value

Outside value

(greater than 1.5 times the IQR)

Upper tail

(less than or equal to 1.5 times the IQR)

$\longleftarrow \quad$ 75th percentile

50th percentile (median or middle value)

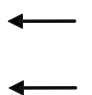

25th percentile

Lower tail

(less than or equal to 1.5 times the IQR) (greater than 3 times the IQR)

Figure 4. Explanation of a boxplot. 
interquartile range (IQR) contains the values between the 25th and 75 th percentiles and is the difference between the 25th and 75th percentiles. The bottom of the vertical line on the boxplot is the smallest value within 1.5 times the IQR of the box. The top of the vertical line on the boxplot is the largest value within 1.5 times the IQR of the box. Outside values are greater than 1.5 times the IQR from the box and outlier values are greater than 3 times the IQR from the box.

\section{Statistical Analyses}

Statistical analyses used in this report include (1) computation of minimum, median, and maximum constituent concentrations, (2) evaluation of temporal variations using the Locally Weighted Scatterplot Smooth (LOWESS) technique, (3) the nonparametric Kruskal-Wallis test, and (4) linear regression techniques. Statistical techniques used in DS load computations are described in the following section of the report.

To evaluate temporal variations in SC values (surrogate for DS concentrations) in surface water at selected sites in the Arkansas River, instantaneous measurements of SC and streamflow were analyzed by using the LOWESS smoothing technique. The smoothing technique LOWESS describes the relation, in this case, between specific conductance and time and(or) between streamflow and time without assuming linearity or normality of the residuals (Helsel and Hirsch, 1992).

The nonparametric Kruskal-Wallis test was used to determine whether there were statistical differences between median concentrations of selenium at selected sites (SYSTAT Software, Inc., 2004). Nonparametric analysis allows the user to analyze data without assuming an underlying distribution. For the purpose of this analysis, the Kruskal-Wallis null hypothesis assumed that the medians of the data groups (that is the median selenium concentrations at the selected sites) were identical. The alternate hypothesis assumed that at least one median differed from the others. The probability value (p-value) is the probability of rejecting the null hypothesis if it is true. A p-value of less than 0.05 was used in this report to indicate if a statistical test was significant.

Specific conductance can be determined in the field using relatively inexpensive equipment and often is used as a surrogate for or to estimate DS concentrations. Specific conductance has been measured more frequently than DS at most water-quality sites in the Arkansas River Basin and found to be highly correlated with DS concentrations (Ortiz and others, 1998). Simple linear-regression relations were developed between instantaneous SC (independent variable) and DS (dependent variable) values at selected surface-water sites using paired data measured from January 1976 through September 2007. Simple linear regression was used to determine the best straight-line fit between two variables (one dependent and one independent variable) and obtain a predictive equation. The coefficient of determination, $r$-squared $\left(r^{2}\right)$, is a statistical measure of how well the predictive equation (regression line) fits the real data points. It varies between 0 and 1 and indicates the amount of variability in the dependent variable described by the independent variable (that is, an $\mathrm{r}^{2}$ value of 0 indicates that there is no relation between the dependent and independent variables; and an $\mathrm{r}^{2}$ value of 1 indicates that there is a perfect relation between the dependent and independent variables). The null hypothesis, in this case, is that there is no relation between the dependent and independent variables (that is, the slope of the regression line is equal to zero). Small p-values suggest that the null hypothesis is unlikely to be true. A p-value of less than 0.05 was used in this report to indicate if a statistical test was significant. The relations between SC and DS (table 3) were used to estimate DS concentrations based on measured SC values.

Relations between SC and DS change in the Arkansas River as it flows downstream (table 3). To explore the effect of using SC and DS relations developed at one location to estimate DS at another location, DS concentrations were computed using the equations shown in table 3 for SC values ranging from 550 to 3,000 microsiemens per centimeter $(\mu \mathrm{S} /$ cm) at Ark Avondale, USGS 07119700 Arkansas River at Catlin Dam near Fowler, Colorado (Ark Catlin Dam), and USGS 07124000 Arkansas River at Las Animas, Colorado (Ark Las Animas). Percent differences in DS concentrations ranged from 0.2 to 3.4 percent between Ark Avondale and Ark Catlin Dam and from 0.05 to 6.1 percent between Ark Catlin Dam to Ark Las Animas. Therefore, estimates of DS concentrations in the Arkansas River at canal headgates between Ark Avondale and Ark Las Animas may range from about 0.2 percent to 6.1 percent higher or lower than the actual value.

\section{Computation of Dissolved-Solids Loads}

Dissolved-solids loads were computed in three different ways depending on the type and quantity of data available at each site. First, at sites having continuous daily mean SC and streamflow data, daily mean DS concentrations were estimated using relations developed between instantaneous SC and DS (shown in table 3) and then multiplied by daily mean streamflow to obtain daily mean DS loads. Second, at selected canals (diverting water from the main-stem Arkansas River between Pueblo Reservoir and John Martin Reservoir) with daily mean diversion data but no daily mean SC data, daily mean SC values were estimated using relations developed between instantaneous SC measured in the canal near the headgate or in the river near the diversion point and daily mean SC measured at a nearby Arkansas River continuous water-quality site. The relation developed between instantaneous SC and DS in the Arkansas River at the site was used to compute daily mean DS concentrations in the canal. For example, instantaneous SC values measured at the Colorado Canal diversion were linearly related to daily mean SC values measured at the Ark Avondale site. Daily mean SC values were computed for the Colorado Canal using this relation (Colorado Canal SC $=1.1^{*}$ Ark at Avondale SC, $\left.r^{2}=0.95\right)$. Then the relation developed 
Table 3. Relations between specific-conductance values and dissolved-solids concentrations in surface water at selected sites in the Arkansas River Basin from Granite, Colorado, to Coolidge, Kansas, 1976-2007.

[N, number of values; DS, dissolved-solids concentration in milligrams per liter; SC, specific conductance in microsiemens per centimeter at 25 degrees Celsius; r-squared, coefficient of determination; $p$-value, probability value; $<$, less than]

\begin{tabular}{|c|c|c|c|c|c|}
\hline Site number & Site name & $\mathbf{N}$ & Equation & r-squared & p-value \\
\hline 07086000 & Ark Granite & 41 & ${ }^{1} \mathrm{DS}=0.6728 * \mathrm{SC}-8.4362$ & 0.91 & $<0.0005$ \\
\hline 07096000 & Ark Canon City & 40 & ${ }^{2} \mathrm{DS}=0.6096 * \mathrm{SC}-6.0311$ & 0.92 & $<0.0005$ \\
\hline 07097000 & Ark Portland & 165 & ${ }^{2} \mathrm{DS}=0.6426 * \mathrm{SC}-6.7052$ & 0.95 & $<0.0005$ \\
\hline 07099400 & Ark Pueblo & 56 & ${ }^{1} \mathrm{DS}=0.7213 * \mathrm{SC}-38.816$ & 0.94 & $<0.0005$ \\
\hline 07106000 & Fnt Fountain & 20 & ${ }^{1} \mathrm{DS}=0.7186 * \mathrm{SC}-56.053$ & 0.99 & $<0.0005$ \\
\hline 07106500 & Fnt Pueblo & 40 & ${ }^{1} \mathrm{DS}=0.7701 * \mathrm{SC}-98.323$ & 0.98 & $<0.0005$ \\
\hline 07108900 & St. Charles River & 19 & ${ }^{1} \mathrm{DS}=0.9717 * \mathrm{SC}-174.3$ & 0.99 & $<0.0005$ \\
\hline 07109500 & Ark Avondale & 55 & ${ }^{1} \mathrm{DS}=0.793 * \mathrm{SC}-89.256$ & 0.98 & $<0.0005$ \\
\hline 07116500 & Huerfano River ${ }^{6}$ & 54 & ${ }^{2} \mathrm{DS}=0.9371 * \mathrm{SC}+167.89$ & 0.93 & $<0.0005$ \\
\hline 07119500 & Apishapa River ${ }^{3}$ & 13 & ${ }^{1} \mathrm{DS}=0.9609 * \mathrm{SC}-259.69$ & 0.98 & $<0.0005$ \\
\hline 07119700 & Ark Catlin Dam & 58 & ${ }^{1} \mathrm{DS}=0.8652 * \mathrm{SC}-145.43$ & 0.98 & $<0.0005$ \\
\hline 07121500 & Timpas Creek ${ }^{4}$ & 18 & ${ }^{1} \mathrm{DS}=0.9527 * \mathrm{SC}-280.28$ & 0.98 & $<0.0005$ \\
\hline HRC194CO & Horse Creek $^{5}$ & 24 & ${ }^{1} \mathrm{DS}=0.9474 * \mathrm{SC}-313.09$ & 0.99 & $<0.0005$ \\
\hline 07124000 & Ark Las Animas & 50 & ${ }^{1} \mathrm{DS}=0.9126 * \mathrm{SC}-230.95$ & 0.95 & $<0.0005$ \\
\hline 07128500 & Purgatoire River & 39 & ${ }^{1} \mathrm{DS}=1.033 * \mathrm{SC}-420.487$ & 0.99 & $<0.0005$ \\
\hline 07130500 & Ark below JMR & 90 & ${ }^{2} \mathrm{DS}=0.8457 * \mathrm{SC}-101.2$ & 0.97 & $<0.0005$ \\
\hline 07137500 & Ark Coolidge & 116 & ${ }^{1} \mathrm{DS}=0.9152 * \mathrm{SC}-9.3173$ & 0.90 & $<0.0005$ \\
\hline
\end{tabular}

${ }^{1}$ Only dissolved-solids concentrations determined by residual on evaporation at 180 degrees Celsius used to develop the relation between dissolved solids and specific conductance.

${ }^{2}$ Dissolved-solids concentrations determined by residual on evaporation at 180 degrees Celsius and sum of constituents were used to develop the relation between dissolved solids and specific conductance.

${ }^{3}$ Relation between specific-conductance values and dissolved-solids concentrations at Apishapa River at Highway 50 near Fowler (USGS Site Number 380715103564701) site used to estimate dissolved-solids concentrations at site 07119500.

${ }^{4}$ Relation between specific-conductance values and dissolved-solids concentrations at Timpas Creek at Highway 50 at Swink (USGS Site Number 380111103382101 ) site used to estimate dissolved-solids concentrations at site 07121500.

${ }^{5}$ Specific-conductance values and dissolved-solids concentrations at Horse Creek at Mouth near Las Animas (USGS Site Number 380421103193101) and Horse Creek near Las Animas (USGS Site Number 07123675) used to develop relation between specific-conductance values and dissolved-solids concentration at Colorado Divison of Water Resources streamgage site HRC194CO.

${ }^{6}$ Specific-conductance values and dissolved-solids concentrations from USGS and Colorado Department of Public Health and Environment were used to develop relation between specific-conductance values and dissolved-solids concentration at the site. 
between instantaneous SC and DS at the Ark Avondale site $\left(\mathrm{DS}=\left[\left(\mathrm{SC}^{*} 0.793\right)-89.256\right]: \mathrm{r}^{2}=0.98\right.$ shown in table 3$)$ was used to compute daily mean DS at the Colorado Canal diversion. These daily mean DS concentrations were multiplied by the daily mean diversions measured at the canal headgate to obtain the daily mean DS load in the canal. Third, at tributary sites with daily mean streamflow data but no daily mean SC measurements, a load estimator model (LOADEST) was used to estimate the average daily mean DS loads from 1995-2006. LOADEST is a FORTRAN program for estimating constituent loads in streams and rivers using a time series of streamflow, additional data variables, and measured constituent concentrations (Runkel and others, 2004). For the purposes of this analysis, daily mean streamflow and miscellaneous measurements of DS were input into the LOADEST program to compute DS loads at the tributary sites. Because far more SC measurements were made at the tributary sites than DS measurements, additional DS concentrations were estimated using relations developed between paired measurements of SC and DS (table 3 ) at the tributary sites. This was done to increase the number of DS values in the concentration input data set and improve model performance.

Calibration and estimation procedures within LOADEST are based on three methods: (1) Adjusted Maximum Likelihood Estimation (AMLE), (2) Maximum Likelihood Estimation (MLE), and (3) Least Absolute Deviation (LAD) (Runkel and others, 2004). The AMLE method was used to estimate DS loads at the selected tributary sites in this report. The AMLE and MLE methods assume that the model residuals are normally distributed. The probability plot correlation coefficients computed by the model were near one, indicating that the assumption of normality was valid (Vogel, 1986; Vogel and McMartin, 1991). When the data set is uncensored (that is values are greater than the reporting level) the AMLE converges to MLE. Only uncensored values were used in this analysis; and the AMLE and MLE converged and produced the same results.

The mean DS load computed by LOADEST was adjusted to account for zero flow days at Huerfano River and Horse Creek. Zero flow days were removed from the streamflow time series input file, and the model was run. The mean DS load output by LOADEST was adjusted by multiplying the mean DS load by the ratio of the number of days with streamflow greater than zero to total number of days in the computation period.

\section{Indicator Kriging}

Indicator kriging, as implemented in ESRI ${ }^{\circledR}$ ArcMap $^{\mathrm{TM}}$ version 9.2 (Environmental Systems Research, Inc., 1999-2006) was used to predict probabilities of exceeding threshold values for concentrations of dissolved uranium in groundwater. It is a method of interpolation which predicts unknown values from data observed at known locations. Indicator kriging is done using indicator variables of measured data rather than the measured data. An indicator variable is a transformation of the measured data (uranium concentration in this analysis) and has two possible values: 0 or 1 . Uranium concentrations less than or equal to $30 \mu \mathrm{g} / \mathrm{L}$ were assigned a value of 0 , and uranium concentrations greater than $30 \mu \mathrm{g} / \mathrm{L}$ were assigned a value of 1 . Interpolated estimates range from 0 to 1 ; and, as used in this report, represent the probability that the value is greater than a threshold value. Two advantages of indicator kriging are that a normal (statistical) distribution of data is not required and that censored values (less than values) are not excluded from analyses (Bossong and others, 1999).

\section{Quality Assurance and Quality Control}

No new data were collected as part of this analysis. Data used in this analysis were compiled from various sources. Each data set was plotted to check for outliers and compared to data collected by other agencies in the surrounding area to verify that the range in concentrations was reasonable prior to inclusion. In addition, if data were available, cation and anion balances were computed for each sample. The sample results were excluded from the analysis if the cation and anion balance varied by more than 5 percent. However, most data used in the analysis were obtained from the USGS and have been reviewed for accuracy and published in various annual data reports (U.S. Geological Survey, 1976-2006, U.S. Geological Survey, 2007 and U.S. Geological Survey, 2008c).

\section{Occurrence and Distribution of Dissolved Solids, Selenium, and Uranium in Groundwater and Surface Water in the Arkansas River Basin from the Headwaters to Coolidge, Kansas}

Dissolved-solids, selenium, and uranium concentrations in groundwater and surface water are influenced by natural hydrogeologic and anthropogenic factors associated with land- and water-use practices. In the following sections of the report: (1) sources of DS, selenium, and uranium in the Arkansas River Basin, (2) groundwater and surface-water data used in the analyses; and (3) the occurrence and distribution of DS, dissolved selenium, and dissolved uranium are discussed.

\section{Sources of Dissolved Solids in the Arkansas River Basin}

Dissolved solids in water are the net effect of a series of antecedent chemical reactions that dissolve material from another phase, alter previously dissolved components, 
or eliminate them from solution by precipitation or other processes (Hem, 1985). The source of most dissolved ions (solids) in water is the mineral assemblage in rocks near the land surface. As rocks are weathered, water flowing across and through rocks will dissolve soluble minerals and chemically react with other minerals, releasing dissolved ions to the water. Most rocks are complex mixtures of minerals that differ widely in their solubility in water; however, except for the evaporites (halite, gypsum, and anhydrite are common evaporite minerals), most minerals are not readily soluble (Hem, 1985). In addition to mineral sources of DS, connate water (water trapped in the pores of a rock during formation of the rock) can contribute DS to groundwater and surface water. Dissolved solids also concentrate in water as a result of evapotranspiration from crops and other vegetation, evaporation from canals and reservoirs, and evaporation from the land surface.

The Precambrian igneous and metamorphic (crystalline) rocks in the Upper Arkansas River Basin, where not affected by mine drainage, do not contribute substantial DS concentrations to groundwater or surface water. Typically, in the Upper Arkansas River Basin, where the crystalline rocks crop out, DS concentrations in groundwater are less than $200 \mathrm{mg} / \mathrm{L}$ and predominantly consist of calcium and bicarbonate. Dissolvedsolids concentrations in streams draining the crystalline rocks and in transmountain diversions are generally less than 100 $\mathrm{mg} / \mathrm{L}$. The sedimentary rocks in the Lower and Middle Arkansas and Fountain Creek drainage basins (particularly the Upper Cretaceous rocks of marine origin including the Pierre Shale, Niobrara Formation, Carlile Shale, Greenhorn Limestone, and Graneros Shale) are a principal source of DS in groundwater and surface water in the Arkansas River Basin. Tourtelot (1962) compared the composition of unweathered Pierre Shale with soil that was derived from residual weathered Pierre Shale and found that sulfides in unweathered shale were oxidized to sulfates during weathering, likely concentrated by evaporation of soil moisture, and precipitated as soluble sulfate minerals in the soil. A generalized order of increasing contribution of DS concentrations for common rocks in the Arkansas River Basin is crystalline rocks, sandstone and conglomerate, dolomite, limestone, shale, and evaporite (Hem, 1985).

Dissolved-solids concentrations in groundwater from alluvial aquifers (HSU 1) upstream from Pueblo ranged from 6.5 to $1,030 \mathrm{mg} / \mathrm{L}$, generally with increasing concentrations in the direction of groundwater flow (Crouch and others, 1984). Dissolved-solids concentrations in groundwater from thick basin-fill aquifers (HSU 2) in Chaffee, Custer, and Lake Counties ranged from 65 to $597 \mathrm{mg} / \mathrm{L}$ with the highest DS concentrations in groundwater in the Upper Arkansas from wells in the Leadville area of Lake County, which were affected by acid mine drainage (Crouch and others, 1984). Crouch and others (1984) found that the quality of water from the DakotaPurgatoire aquifer was highly variable, with DS concentrations that ranged from 126 to $3,960 \mathrm{mg} / \mathrm{L}$; and the lowest concentrations of DS from the Dakota-Purgatoire aquifer occurred near outcrop areas of the Dakota Sandstone. In eastern Colorado, DS concentrations in groundwater ranged from 200 to 4,000 $\mathrm{mg} / \mathrm{L}$ in the Laramie-Fox Hills aquifer (HSU 3), from less than 500 to more than $6,000 \mathrm{mg} / \mathrm{L}$ in the Fort Hays-Codell aquifer (HSU 6), from 200 to 31,900 mg/L in the Dakota-Purgatoire aquifer (HSU 7), from 250 to more than 5,000 $\mathrm{mg} / \mathrm{L}$ in the Lyons aquifer (HSU 10), and from 200 to $500 \mathrm{mg} / \mathrm{L}$ in the Fountain aquifer (HSU 10) near its outcrop along the mountain front (Robson and Banta, 1987).

In general, groundwater quality is better in aquifers that are recharged by precipitation than in aquifers recharged by irrigation water in the Arkansas River Basin, because DS concentrations in precipitation are typically lower than DS concentrations in irrigation waters. Stream-aquifer interaction and irrigation likely affect groundwater quality. Irrigation in stream-aquifer systems, like those in the Fountain Creek and Arkansas River valleys, can increase the DS concentration in groundwater and in surface water because part of the irrigation water is consumed by evapotranspiration (consumptive use), leaving behind salts in the soil or increased DS in the unconsumed water, or some in both. Additional minerals in the soil and aquifer also may dissolve as the water flows through the soil and unsaturated zone and into and through the aquifer. Eventually, when groundwater returns to the stream as base flow, it can be diverted again for irrigation; and the cycle repeats, resulting in increased concentrations of DS in groundwater and surface water in a downstream direction (Miles, 1977).

\section{Sources of Selenium in the Arkansas River Basin}

Selenium is a naturally occurring trace element that can be either beneficial or toxic to plants, animals, and humans depending on its concentrations. Weathering and oxidative remobilization of reduced selenium from shale and chalk can result in selenium concentrations in water that exceed the maximum contaminant level (MCL) in drinking water of 50 $\mu \mathrm{g} / \mathrm{L}$ (U.S. Environmental Protection Agency, 2003a).

Sources of selenium are widely distributed throughout the Great Plains, including the Colorado Piedmont and Raton sections (fig. 2A) in the Arkansas River Basin in Colorado. During the Cretaceous age there was extensive volcanic activity throughout the land mass from which Cretaceous sediments were derived, and it is likely that much of the selenium in the sedimentary rocks was derived from volcanic dusts and gases (Ihnat, 1989). A summary of some of the research done during the 1930s and 1940s concluded that "all areas of soils derived from material of Cretaceous age are then open to suspicion of the presence of harmful quantities of selenium" (Lakin and Byers, 1941). The Cretaceous marine shale and limestone that crop out throughout most of the Colorado Piedmont and the Raton sections of the Great Plains province in the Arkansas River Basin are a source of selenium (figs. 2A and 2B). Landis (1959) reported selenium contents of 0.001 to 0.005 percent 
(10 to $50 \mu \mathrm{g} / \mathrm{kg}$ ) by weight in samples of the Upper Cretaceous Pierre Shale and Niobrara Formation of Colorado and Kansas; and Kulp and Pratt (2004) reported average selenium content in core samples from the Pierre Shale and Niobrara Formation in South Dakota and Wyoming of 0.0034 percent (34.48 $\mu \mathrm{g} / \mathrm{kg}$ ) by weight. Elevated concentrations of selenium in groundwater are associated with weathering of rocks, particularly the lower part of the Cretaceous Pierre Shale and the upper part of the Niobrara Formation. Outcrops of the Pierre Shale, Niobrara Formation (shale and limestone), and Carlile Shale are exposed extensively in the study area. As a result, selenium leached from the parent material could accumulate in the soils and shallow groundwater in the study area (Mueller and others, 1991). Selenium concentrations in groundwater north of the Arkansas River alluvium in Crowley and Kiowa Counties, Colo., frequently exceeded $10 \mu \mathrm{g} / \mathrm{L}$ and were as high as $124 \mu \mathrm{g} / \mathrm{L}$ (Cain and others, 1980b; Mustard and Cain, 1981).

High concentrations of selenium in surface water may indicate runoff from land underlain by marine shale and(or) inflow from groundwater which may be compounded by extensive application of irrigation water that can leach selenium from the soil and underlying rock. For example, Thomas and others (2008) in summarizing studies of selenium in the Gunnison River Basin (Butler and others, 1991, 1996; Wright and Butler, 1993; Butler, 2001; Butler and Leib, 2002) reported that the variation in the magnitude of selenium concentration and load in streams was directly related to the application of irrigation water on soils derived from the Mancos Shale. The Mancos Shale is an Upper Cretaceous, massive, and fossiliferous marine shale with interbedded sandstone, siltstone, and devitrified volcanic ash layers, and is the lateral equivalent to the Niobrara Formation, Cody Shale, and Pierre Shale in Colorado, Montana, Nebraska, South Dakota, and Wyoming (Wright and Butler, 1993).

\section{Sources of Uranium in the Arkansas River Basin}

Most natural waters contain detectable amounts of uranium. Uranium concentrations in groundwater and surface water vary greatly; the concentration of uranium in most groundwater and surface water is less than $10 \mu \mathrm{g} / \mathrm{L}$ (Barker and others, 1965). Dissolution of uranium can occur when oxygen-rich alkaline groundwater flows through rocks containing uranium. Where oxidizing conditions dominate, uranium becomes soluble (Felmlee and Cadigan, 1979; Lindsey and Clarke, 1995) and is readily transported in groundwater. The concentration of uranium in oxidizing groundwater tends to reach a value roughly proportional to the uranium concentration in the rocks through which it flowed (Wenrich-Verbeek, 1980). In-situ mining of uranium is done by circulating an oxygenated alkaline solution into subsurface uranium deposits to dissolve the uranium so it can be pumped to the surface (Pelizza, 2008). The downstream increase in alkalinity of groundwater and surface water in the Arkansas River Valley between Pueblo and the Colorado-Kansas State line is one of the factors that causes a downstream increase in dissolveduranium concentrations in groundwater and the surface water receiving it.

Sources of uranium are widely distributed throughout the Arkansas River Basin and occur in all types of rocks, ranging from Precambrian crystalline rocks to unconsolidated Quaternary alluvial deposits (fig. 2B). Uranium source rocks in the basin include Precambrian-age granitic rocks in Teller County (Pitkin and Long, 1977), Paleozoic-age redbeds (sandstone and conglomerate) in the Sangre De Cristo Mountains in Custer County (Lindsey and Clarke, 1995), Mesozoic-age sedimentary rocks (Morrison Formation, Dakota Sandstone, Niobrara Formation, and Pierre Shale), Tertiary-age alluvium, gravel, and tuff (consolidated volcanic ash) in western Fremont County (Dickinson, 1981; Dickinson and Hills, 1982; Hills and Dickinson, 1982; Hon, 1984), and Tertiary-age intrusive rocks and volcanic ash in the Wet Mountain Valley in Custer County (Scott and Taylor, 1975). Uranium concentrations in the lower part of the Pierre Shale in the Arkansas Valley generally are 0.001 percent (10 parts per million (ppm)) by weight or less. Locally, in individual beds, uranium concentrations ranged from 0.002 to 0.006 percent (20 to $60 \mathrm{ppm}$ ) (Landis, 1959). Surface and subsurface data indicate that the most radioactive part of the Pierre Shale is persistent for at least 5.5 miles in Crowley County, Colo. (Landis, 1959). Zielinski and others (1995) found that natural oxidative weathering of uranium-bearing marine shale bedrock, leaching of shalederived soils, and evaporative concentration produces average dissolved-uranium concentrations that approach or exceed 20 $\mu \mathrm{g} / \mathrm{L}$ in surface water and shallow groundwater in southeastern Colorado. In addition, locally extensive use and reuse of water in the Arkansas River valley for irrigation further elevates dissolved-uranium concentrations in irrigation return flow by increasing the amount of water/soil and water/rock interaction and the potential for evaporative concentration (Zielinski and others, 1995).

\section{Groundwater and Surface-Water Data Used to Characterize the Occurrence and Distribution of Dissolved Solids, Selenium, and Uranium in the Arkansas River Basin}

The occurrence and distribution of each constituent (DS, dissolved selenium, and dissolved uranium) is discussed separately for groundwater and surface water in the following sections of the report.

Groundwater quality varies both spatially and temporally within the Arkansas River Basin but generally the data are insufficient to define that variability on a regional scale or for multi-decadal periods. Most of the available groundwaterquality studies have been conducted for specific areas and aquifers and were generally for limited durations. The exceptions are the National Uranium Resource Evaluation (NURE) program in the 1970s, which sampled groundwater and surface 
water nationwide at relatively high spatial density, ongoing research of salinity and water management in the Arkansas River Valley by Colorado State University's Lower Arkansas River Valley Research, and the water-quality monitoring network operated by the CDA. Water-quality data for groundwater in the Arkansas River Basin collected by the USGS for water-resources investigations are available throughout the basin but generally represent data collected at different times for site-specific studies. Only data collected since 1970 were compiled for this study.

The number of groundwater sites and samples used in this analysis are summarized by data source in table 4 for the selected water-quality characteristics. Figures $5 \mathrm{~A}, 5 \mathrm{~B}$, and $5 \mathrm{C}$ show the location of and data source for selected groundwaterquality sites used in this analysis. Table 4 lists the data sources and numbers of groundwater sites and samples with SC values and concentrations of DS, dissolved selenium, and dissolved uranium. Additional water-quality data for groundwater sites in the study area are available from environmental investigations conducted under the Comprehensive Environmental Response, Compensation, and Liability Act (CERCLA) at Superfund sites and under the Resource Conservation and Recovery Act (RCRA). These data, however, are not included in this analysis because of the potential for bias in the results from potentially contaminated sites.

Groundwater sites were grouped according to hydrostratigraphic units to compare differences in water quality. Groundwater in the alluvial aquifer (HSU 1) adjacent to the Arkansas River and its tributaries is hydraulically connected to surface water. Groundwater in the alluvial aquifer, in particular, may provide base flow and is a source of solutes to surface water or may be recharged by and possibly diluted by surface water, depending on the direction of hydraulic gradient between stream stage and groundwater levels. HSU 1 overlies HSU 6 (fig. 2B) in much of the basin; as a result, groundwater quality in HSU 1 may be affected by contact with rocks from and interaction with groundwater in HSU 6. Groundwaterquality results from HSU 1 and HSU 6 are discussed in greater detail than other HSU's in this report due to potential effects on surface-water quality in the Arkansas River and Fountain Creek.

For surface water, the areas of discussion are limited to the main-stem Arkansas River from the headwaters to Ark Coolidge, Fountain Creek, and major tributaries flowing into and major canals diverting water from the Arkansas River between Pueblo Reservoir and John Martin Reservoir. The following discussion utilizes (1) periodic streamflow and surface-water-quality data collected from January 1976 through September 2007 by the USGS, City of Pueblo, CDPHE, and CSUFC (Horse Creek site only) and (2) daily mean SC, streamflow, and diversion data collected from January 1995 through December 2006 by the USGS and CDWR. In addition, available instantaneous $\mathrm{SC}$ and streamflow data at selected sites on the Arkansas River were used to examine temporal variations in SC values (surrogate for DS concentrations) and streamflow. Generally, instantaneous SC values and streamflow were measured at the selected sites beginning between 1960 and 1975 through present (2009).

It should be noted that (1) the number of surface-water samples analyzed for DS, selenium, and uranium varies from site to site, (2) the sampling period varies from site to site, (3) samples may not have been collected over a wide range of flow regimes at all sites, and (4) uncertainty, due to measurement errors and spatial and temporal variability, is associated with constituent concentrations and streamflow values. Consequently, the variability in DS, selenium, and uranium concentrations and instantaneous mass loads for selenium and uranium along the main stem of the Arkansas River, Fountain Creek, and other tributaries may not be fully represented in the following analyses.

In the surface-water quality sections of the report, constituent concentrations and mass loads are discussed on a reach-by-reach basis. The first reach extends from the headwaters of the Arkansas River to Pueblo Reservoir. The second reach extends from Pueblo Reservoir to Ark Avondale (inset fig. 2), the third reach includes Fountain Creek from Colorado Springs to the confluence with the Arkansas River, and the final reach extends from Ark Avondale to Ark Coolidge.

\section{Dissolved Solids and Specific Conductance in Groundwater in the Arkansas River Basin}

Variability of DS concentrations in groundwater is large in the Arkansas River Basin, ranging from about 50 to more than 70,000 mg/L (fig. 6). Variability of DS concentrations between and within HSUs is large, particularly for the Quaternary alluvial, glacial drift, and wind-laid deposits (HSU 1), the Upper Cretaceous shale and limestone (HSU 6), and the Lower Cretaceous sandstone and shale (HSU 7). Dissolvedsolids concentrations in groundwater from HSU 1 increase downgradient (fig. 7) with median values of about 220, 700, 1,700, and 3,400 mg/L in the Upper Arkansas, Fountain Creek, Middle Arkansas, and Lower Arkansas subbasins, respectively. Dissolved-solids concentrations in groundwater from HSU 6 also increase downgradient (fig. 7) with median values of about 2,100, 2,300, and 3,700 mg/L in the Fountain Creek, Middle Arkansas, and Lower Arkansas subbasins, respectively. The relatively large down-basin increases in DS concentrations in groundwater from HSU 1 likely result from two processes: evapoconcentration of DS (due to evapotranspiration from vegetation and evaporation of water from canals, reservoirs, and the land surface) and mixing with groundwater from HSU 6. The relative contributions from these processes are not known. Darton (1906, p. 81) reported that DS concentrations in water from 29 wells completed in the Dakota Sandstone (HSU 7) in the Arkansas River Valley between Granada and Pueblo ranged from 318 to 9,350 $\mathrm{mg} / \mathrm{L}$. These values are approximately within the range of DS concentrations for HSU 7 measured in groundwater samples collected from 1970-2008 shown in figure 6. The HSUs with the lowest median concentrations were HSUs 3, 4, and 12, with median 
Table 4. Data sources and numbers of groundwater sites and samples with concentrations of dissolved solids, dissolved selenium, dissolved uranium, and specificconductance values, Arkansas River Basin, Colorado, August 1970 through August 2008. [USGS, U.S. Geological Survey]

\begin{tabular}{|c|c|c|c|c|c|c|c|c|}
\hline \multirow[t]{2}{*}{ Data source } & \multicolumn{2}{|c|}{ Dissolved solids } & \multicolumn{2}{|c|}{ Specific conductance } & \multicolumn{2}{|c|}{ Dissolved selenium } & \multicolumn{2}{|c|}{ Dissolved uranium } \\
\hline & Sites & Values & Sites & Values & Sites & Values & Sites & Values \\
\hline Colorado Department of Agriculture & 0 & 0 & 159 & 159 & 0 & 0 & 0 & 0 \\
\hline Colorado State University, Fort Collins & 158 & $875^{\mathrm{a}}$ & 159 & 1,001 & 166 & 1,773 & 160 & 441 \\
\hline USGS National Uranium Resource Evaluation & 0 & 0 & 2,501 & 2,501 & 0 & 0 & 2,480 & 2,480 \\
\hline USGS National Water Information System & 567 & $707^{\mathrm{b}}$ & 717 & 1,554 & 148 & 250 & 66 & 67 \\
\hline Totals & 748 & 1,680 & 3,558 & 5,307 & 335 & 2,105 & 2,706 & 2,988 \\
\hline
\end{tabular}

a All dissolved-solids concentrations calculated as the sum of constituents.

b Some dissolved-solids concentrations calculated as the sum of constituents. 

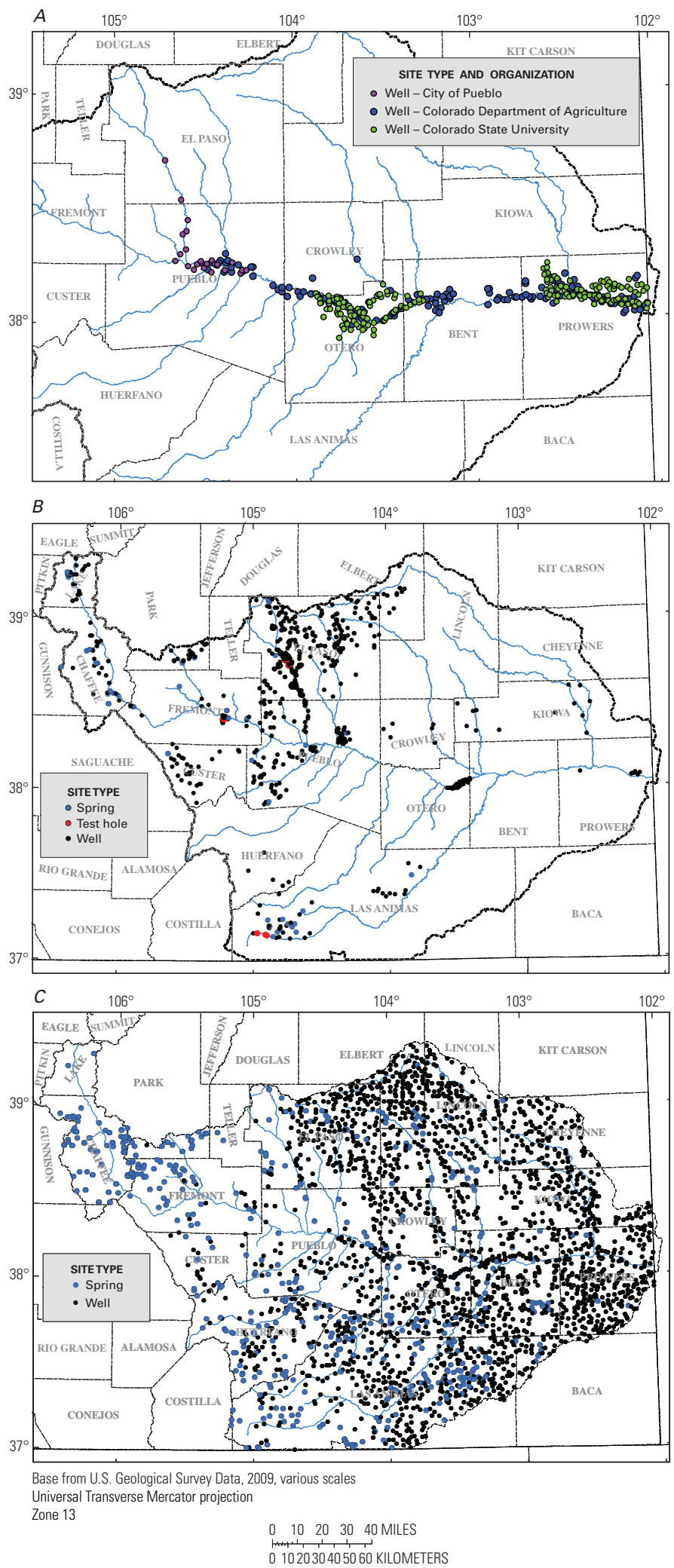

Figure 5. Locations of $(A)$ City of Pueblo, Colorado Department of Agriculture, and Colorado State University Lower Arkansas River Valley Research, (B) U.S. Geological Survey National Water Information System, and (C) National Uranium Evaluation groundwaterquality sites (wells, springs, and test holes) with results for one or more of selected water-quality characteristics, Arkansas River Basin, Colorado, August 1970 through August 2008. 


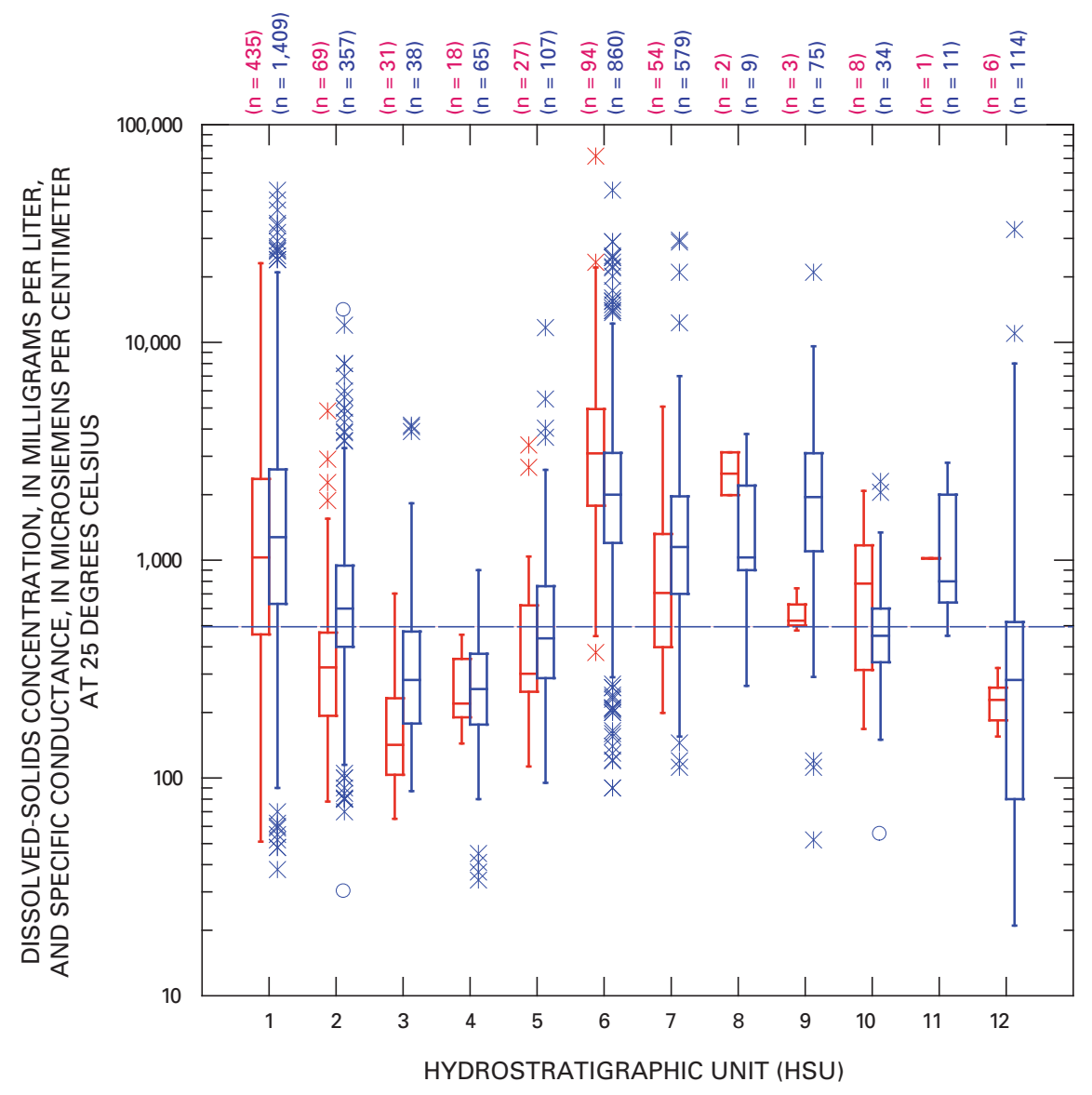

EXPLANATION

Dissolved solids

n Number of sites
Specific conductance
Secondary Drinking Water Standard 500 milligrams per liter

(U.S. Environmental Protection Agency, 2003b)

HYDROSTRATIGRAPHIC
UNIT
NUMBER
1

2
3
4
5
6
7
8
9
10
11
12

HYDROSTRATIGRAPHIC UNIT AND PRIMARY LITHOLOGY

[shown in figure 2]

Quaternary alluvial, glacial drift, and wind-laid

(unconsolidated) deposits

Tertiary sandstone and conglomerate

Tertiary siltstone, mudstone, shale, and coal

Tertiary igneous rocks (includes tuff)

Upper Cretaceous sandstone, shale, and coal

Upper Cretaceous shale and limestone

Lower Cretaceous sandstone and shale

Jurassic-Triassic sandstone and conglomerate

Jurassic-Triassic mudstone, shale, and siltstone

Paleozoic sandstone and conglomerate

Paleozoic shale, limestone, and dolomite

Cambrian and Precambrian crystalline

(igneous and metamorphic) rocks

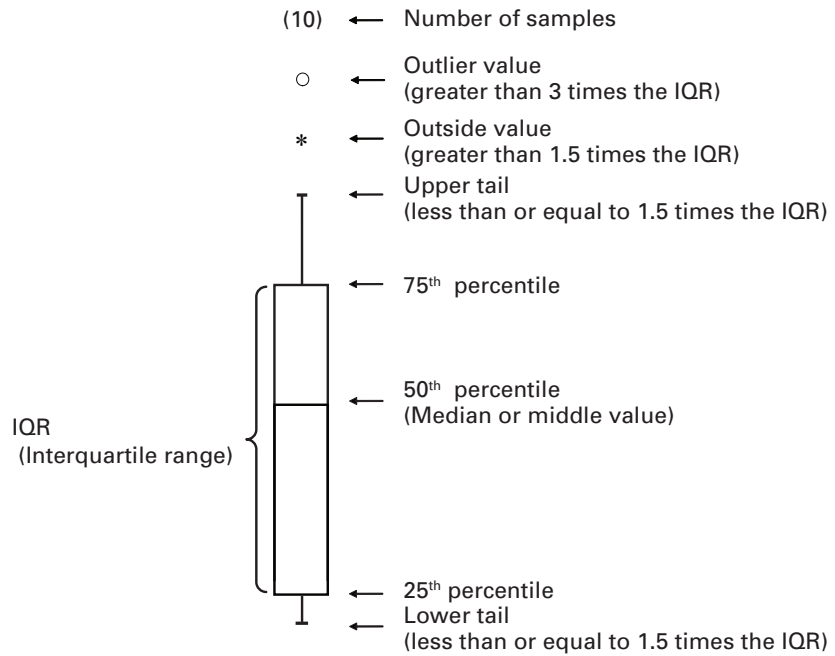

Figure 6. Median dissolved-solids concentration and specific-conductance values in groundwater by hydrostratigraphic unit and primary lithology, Arkansas River Basin, Colorado. 

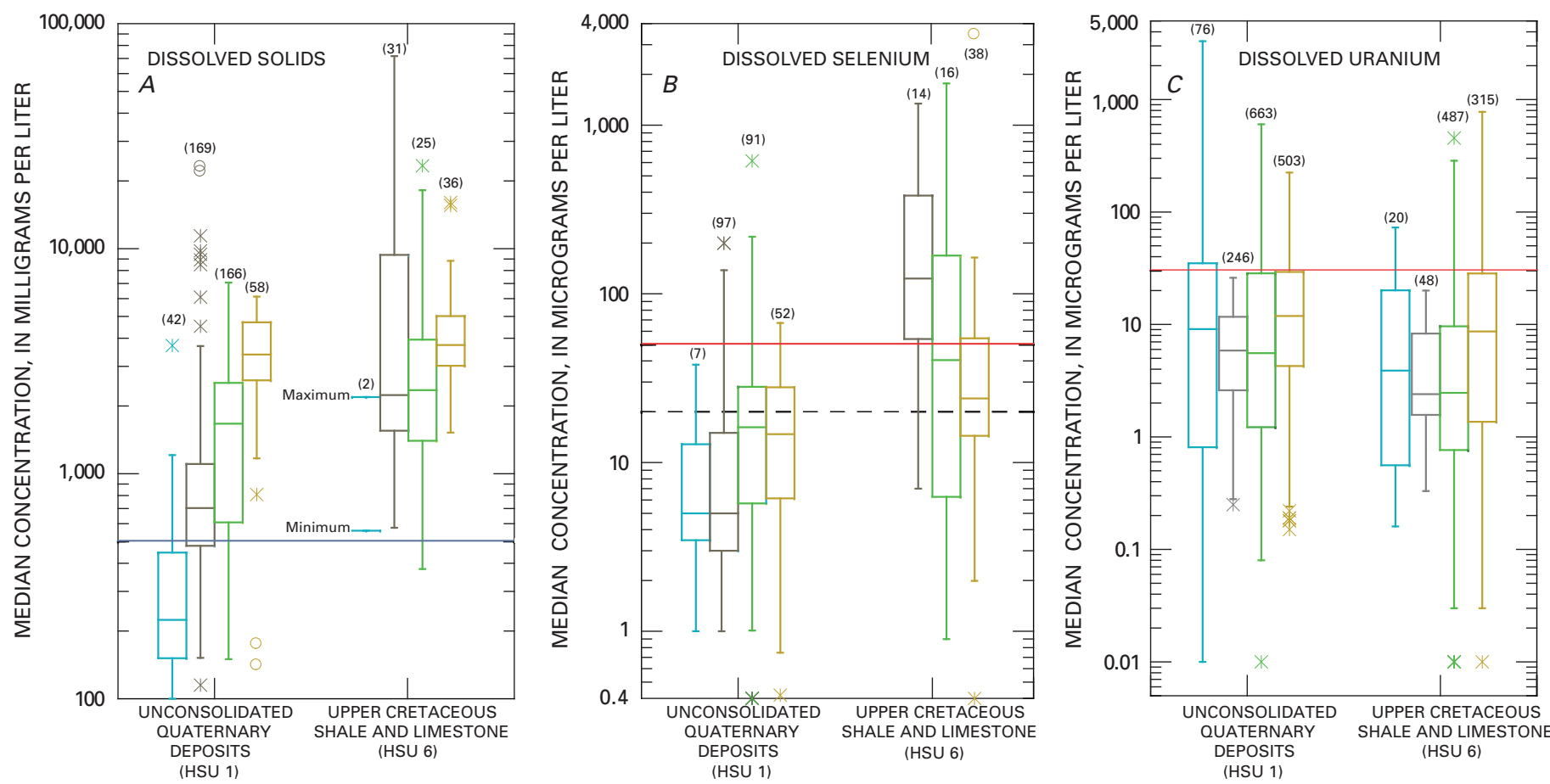

EXPLANATION

n Number of sites with median values

- National Primary Standard for drinking water cy, 2003a) National Secondary Standard for drinking water
(U.S. Environmental Protection Agency, 2003b)

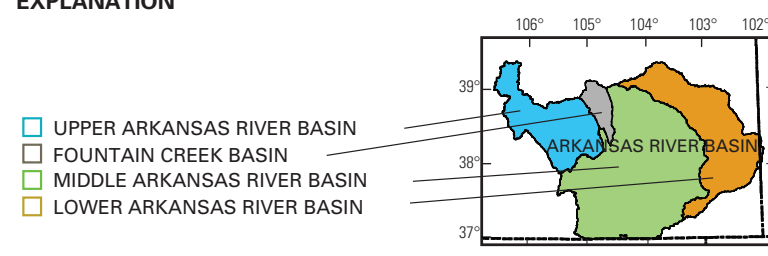

- Colorado Agricultural Water Standard

(Colorado Department of Public Health and
Environment Water Quality Control Commission, 2009b)

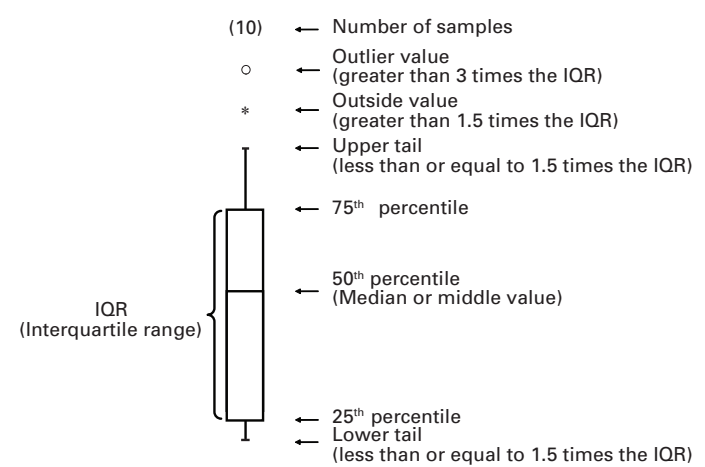

Figure 7. Boxplots showing variation in median concentrations of $(A)$ dissolved solids, $(B)$ disso
selenium, and $(C)$ dissolved uranium in groundwater from unconsolidated Quaternary deposits

(hydrostratigraphic unit 1 [HSU1]) and from Upper Cretaceous shale and limestone (hydrostratigraphic unit 6 [HSU 6]), in the Arkansas River Basin, Colorado. 


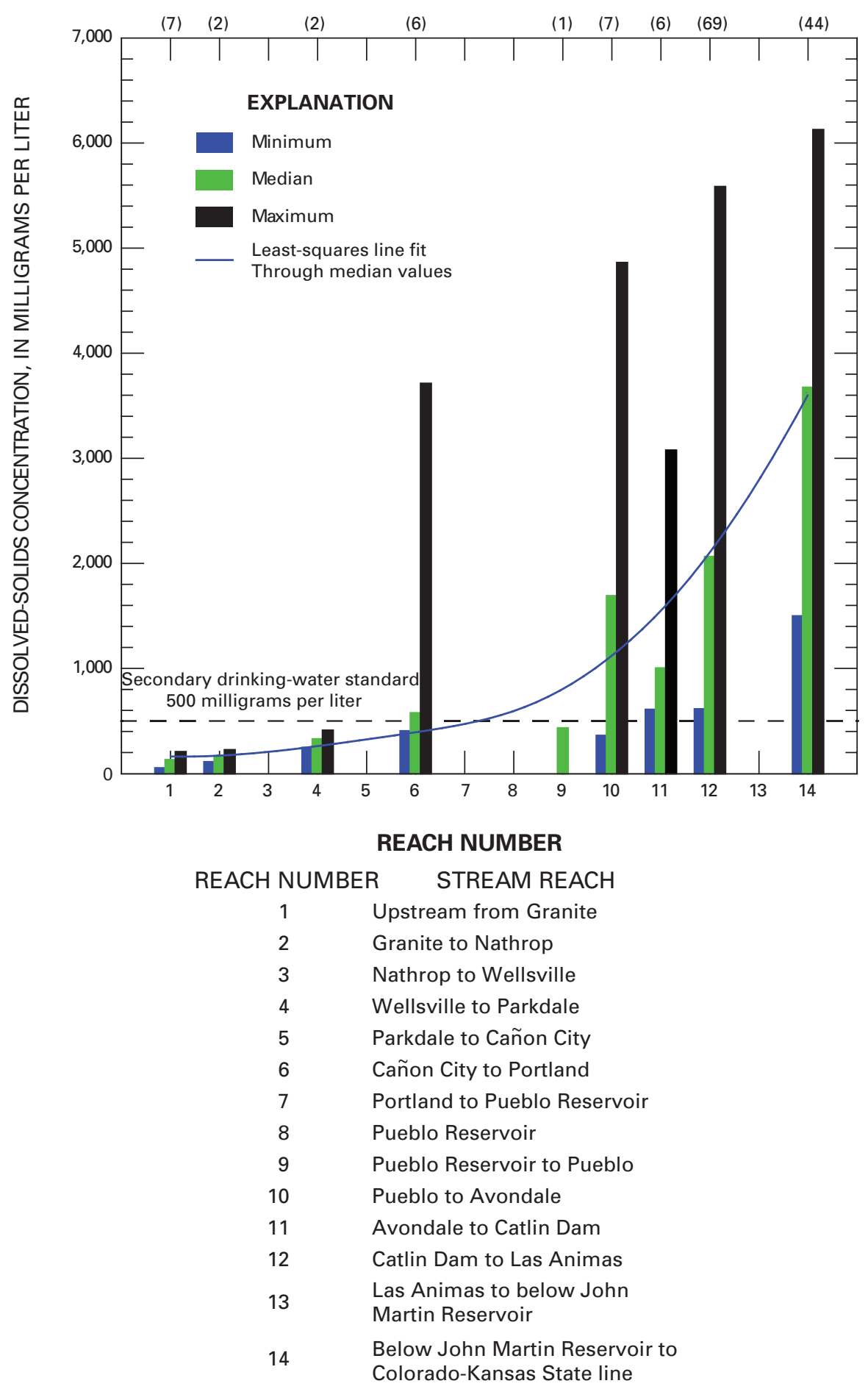

Figure 8. Variability in dissolved-solids concentrations in groundwater from unconsolidated Quaternary deposits (hydrostratigraphic unit 1) within 2 miles of the Arkansas River in Colorado. 

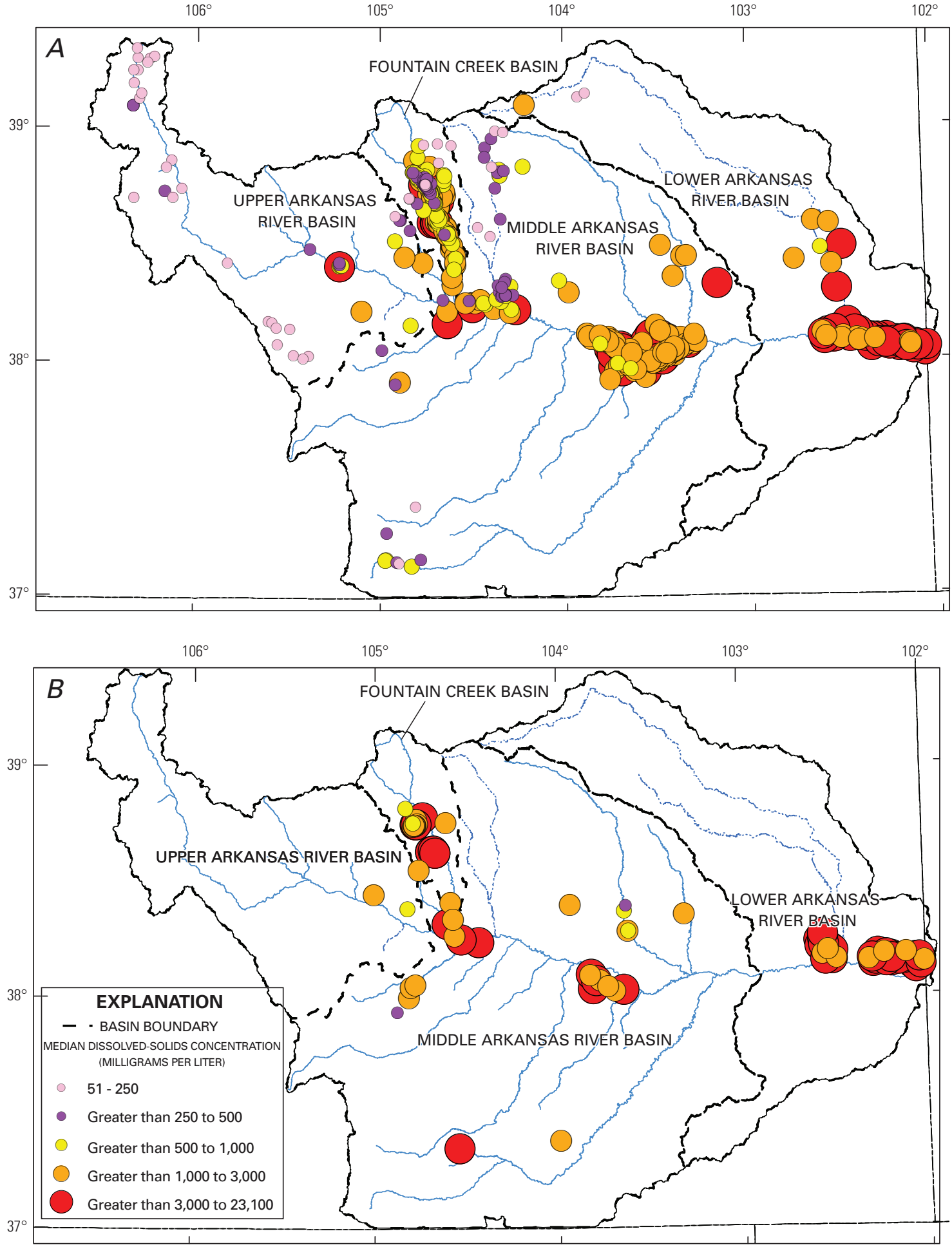

Base from U.S. Geological Survey Data, 2009, various scales Universal Transverse Mercator projection Zone13

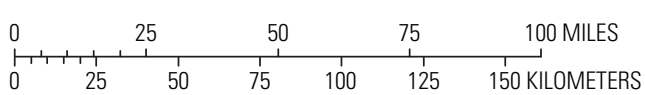

Figure 9. Median dissolved-solids concentrations in $(A)$ unconsolidated Quaternary deposits (hydrostratigraphic unit 1) and (B) Upper Cretaceous shale and limestone (hydrostratigraphic unit 6) in the Arkansas River Basin, Colorado. 

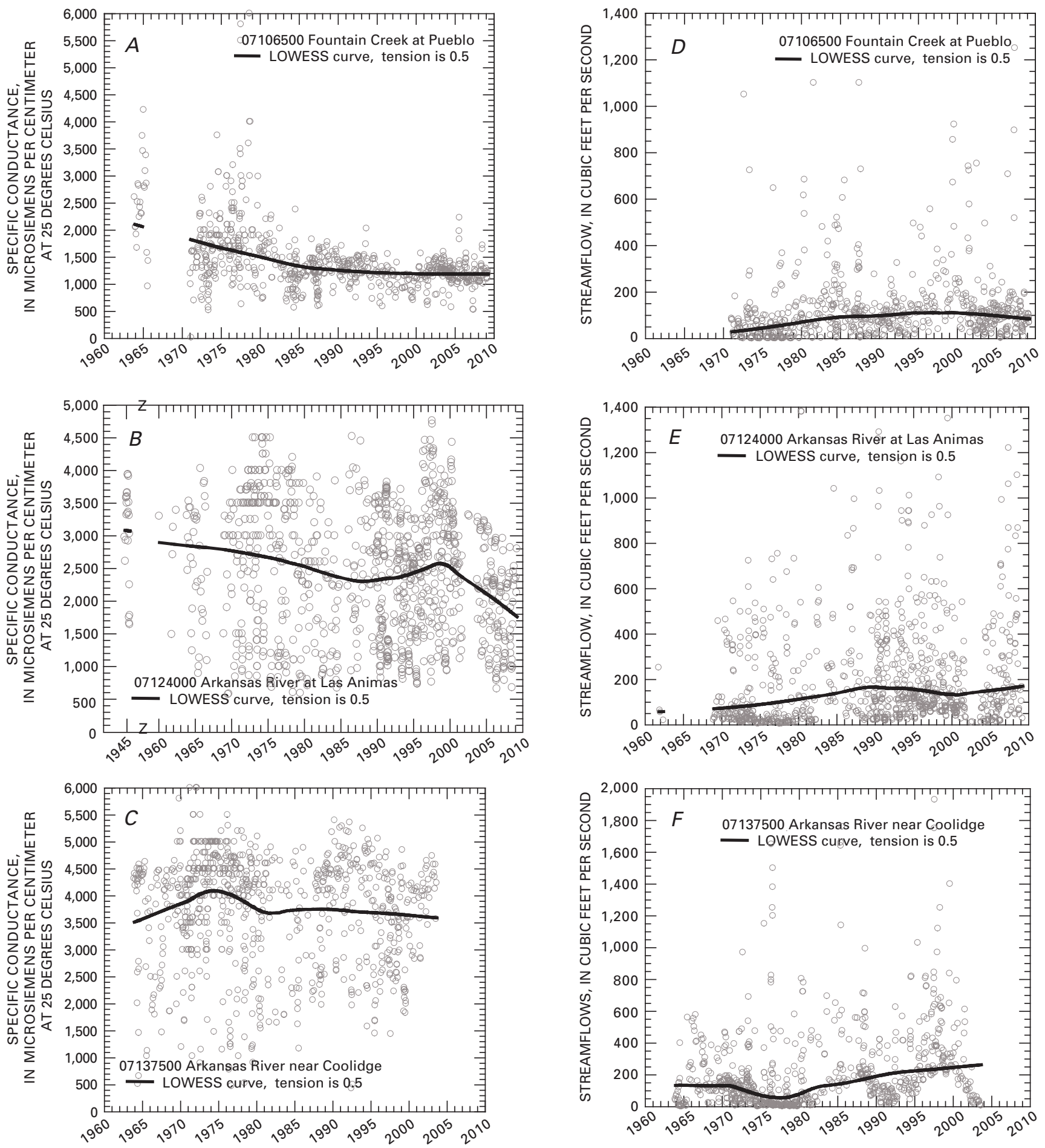

Figure 10. Temporal variation in instantaneous $(A-C)$ specific-conductance values and $(D-F)$ streamflow at selected sites in the Arkansas River Basin, 1945-2008. 
DS concentrations less than $250 \mathrm{mg} / \mathrm{L}$ (fig. 6). Because the number of sample sites with DS results for HSUs 8-12 is small, the variability of DS concentrations probably is under represented in comparison with SC values for the same HSUs (fig. 6).

Variability of SC values also is large in groundwater from the Arkansas River Basin, ranging from about 20 to more than $50,000 \mu \mathrm{S} / \mathrm{cm}$ (fig. 6). Like DS, SC values had a large range for water from HSUs 1, 6, and 7. In addition, SC values also had a large range in groundwater from HSU 12, the Cambrian and Precambrian crystalline rocks, with two samples having SC values greater than $10,000 \mu \mathrm{S} / \mathrm{cm}$. Cain (1985) found that groundwater pumped from the alluvial aquifer adjacent to the Arkansas River showed a large downstream increase in SC, and SC in groundwater was generally higher than in the river upstream from Lamar. However, SC values in groundwater and in the Arkansas River were similar in the reach between Lamar and the Colorado-Kansas State line (Cain, 1985).

Based on data used in this analysis, there is a general increase in concentrations of DS in groundwater between Granite and the Colorado-Kansas State line (figs. 8 and 9). The minimum, median, and maximum DS concentrations in groundwater from HSU 1 (unconsolidated Quaternary deposits) within 2 miles of the Arkansas River between Granite and the Colorado-Kansas State line increase substantially in the downstream direction (fig. 8). Median concentrations of DS in groundwater increase from less than $200 \mathrm{mg} / \mathrm{L}$ in HSU 1 upstream from Nathrop to about 400 mg/L between Wellsville and Parkdale (fig. 8). Between Cañon City and Portland, median DS concentrations in groundwater exceed $500 \mathrm{mg} / \mathrm{L}$ (fig. 8) (the national secondary drinking water standard for DS; U.S. Environmental Protection Agency, 2003b). Between Pueblo and Avondale, median DS concentrations from HSU 1 increase to about 1,600 mg/L; between Catlin Dam and Las Animas, they increase to about 2,000 mg/L; and downstream from John Martin Reservoir, they increase to about 3,600 mg/L (fig. 8). The variability in DS concentrations in groundwater within 2 miles of the Arkansas River, as indicated by the differences in minimum and maximum values, also increases in a downstream direction (fig. 8).

\section{Temporal Variations in Specific-Conductance Values in Surface Water in the Arkansas River}

Because SC values are highly correlated with DS concentrations in surface water in the Arkansas River Basin (see table 3), variations in SC with time likely reflect variations in DS with time. LOWESS curves were generated using instantaneous values of specific conductance and streamflow measured at selected sites generally from 1960 through 2008; specific conductance values measured in 1945 at Ark Las Animas were also included in the analysis (fig. 10). Figure 10 shows LOWESS curves for instantaneous SC values and streamflow over time at USGS 07106500 Fountain Creek at Pueblo, Colorado (Fnt Pueblo), streamgage, Ark Las Animas, and Ark Coolidge.
LOWESS curves for additional sites are shown in Appendix 2 at the end of the report. At Fnt Pueblo, the LOWESS curve (fig. 10A) shows a general decrease in SC values from 1964 to about 1995; whereas, figure 10D shows a general increase in streamflows from 1964 to about 1995 at Fnt Pueblo. Specific conductance values in Fountain Creek at Fnt Pueblo remained relatively constant from 1995 through 2008 (fig. 10A); and, during the same period, streamflows remained relatively constant or decreased (fig. 10D). The LOWESS curves for SC and streamflow at Ark Las Animas (figs. 10B and 10E) show that, overall, SC values have decreased and streamflows have increased. Visual inspection of the remaining LOWESS curves shows that, for the most part, SC values in the Arkansas River have remained relatively constant or have decreased since about 1970 (fig. 10 and Appendix 2).

\section{Dissolved Solids in Surface Water in the Arkansas River Basin from Granite, Colorado, to Coolidge, Kansas}

Dissolved-solids concentrations in the Arkansas River increased substantially in the downstream direction within the study area. Figure 11 shows the spatial distribution of DS concentrations in the Arkansas River from USGS 07086000 Arkansas River at Granite, Colorado (Ark Granite), to Ark Coolidge for data collected from 1976 through 2007. Median DS concentrations increased from about $64 \mathrm{mg} / \mathrm{L}$ at Ark Granite to about 4,060 mg/L at Ark Coolidge (fig. 11 and table 5) representing more than a 6,000 percent increase in median DS concentrations. Based on crop tolerances and other factors, Ayers and Westcot (1985) report slight to moderate restrictions for use of irrigation water with DS concentrations between 450 to $2,000 \mathrm{mg} / \mathrm{L}$ and severe restrictions in use for DS concentrations greater than 2,000 $\mathrm{mg} / \mathrm{L}$. Dissolved-solids concentrations at main-stem sites downstream from Ark Avondale generally exceeded the secondary maximum contaminant level of 500 mg/L for DS in drinking water (U.S. Environmental Protection Agency, 2003b) and downstream from USGS 07130500 Arkansas River below John Martin Reservoir, Colorado (Ark below JMR), concentrations generally exceeded 2,000 mg/L in more than 50 percent of samples (fig. 11).

Dissolved-solids concentrations were higher in the Arkansas River during the nonirrigation season (NovemberFebruary) than during the irrigation season (March-October) (fig. 12A). However, figure 12B shows that average annual DS loads were lower during the nonirrigation season and higher during the irrigation season because average annual flows in the Arkansas River (1995-2006) were at least two times higher during the irrigation season than during the nonirrigation season at all main-stem sites (fig. 12C). Average annual DS loads during the irrigation season were at least two times and as much as 23 times higher than average annual DS loads during the nonirrigation season with the largest differences occurring at sites located immediately downstream from the two 
Table 5. Summary of dissolved-solids, dissolved-selenium, and dissolved-uranium concentrations in surface-water samples at selected sites in the Arkansas River Basin, 1976-2007.

[USGS, U.S. Geological Survey; CDPHE, Colorado Department of Public Health and Environment; COP, City of Pueblo; N, number of samples; Min, minimum value; Max, maximum value; Med, median value; $\mathrm{mg} / \mathrm{L}$, milligram per liter; $\mu \mathrm{g} / \mathrm{L}$, microgram per liter; <, less than; --, no data; highlighted areas, inflow to Arkansas River]

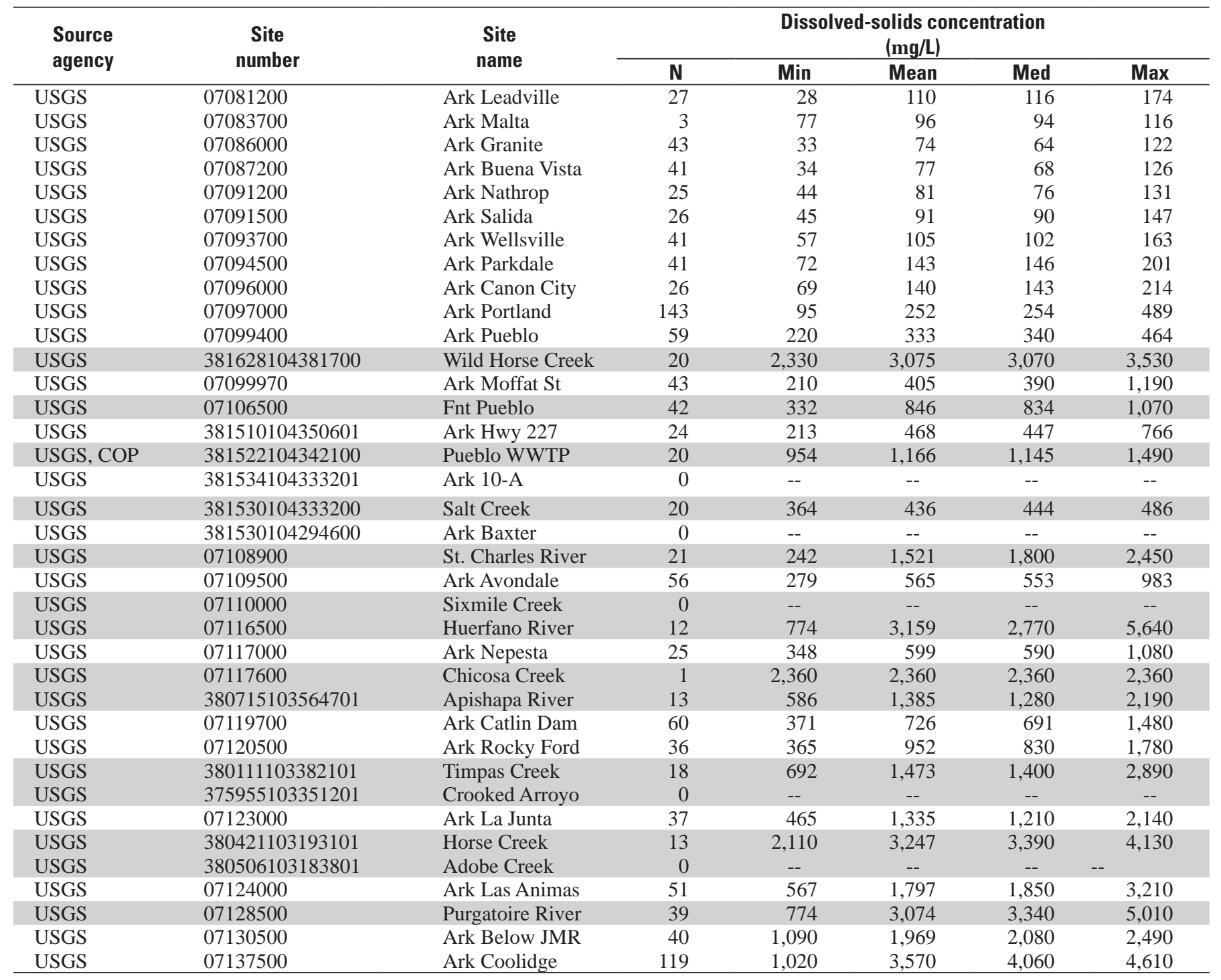


Table 5. Summary of dissolved-solids, dissolved-selenium, and dissolved-uranium concentrations in surface-water samples at selected sites in the Arkansas River Basin, 1976-2007.-Continued.

[USGS, U.S. Geological Survey; CDPHE, Colorado Department of Public Health and Environment; COP, City of Pueblo; N, number of samples; Min, minimum value; Max, maximum value; Med, median value; $\mu \mathrm{g} / \mathrm{L}$, milligram per liter; $\mu \mathrm{g} / \mathrm{L}$, microgram per liter; $<$, less than; --, no data; highlighted areas, inflow to Arkansas River]

\begin{tabular}{|c|c|c|c|c|c|c|c|c|c|c|}
\hline \multirow{2}{*}{$\begin{array}{l}\text { Source } \\
\text { agency }\end{array}$} & \multicolumn{5}{|c|}{$\begin{array}{c}\text { Dissolved-selenium concentration } \\
(\mu \mathrm{g} / \mathrm{L})\end{array}$} & \multicolumn{5}{|c|}{$\begin{array}{c}\text { Dissolved-uranium concentration } \\
(\mu \mathrm{g} / \mathrm{L})\end{array}$} \\
\hline & $\mathbf{N}$ & Min & Mean & Med & Max & $\mathbf{N}$ & Min & Mean & Med & Max \\
\hline USGS & 0 & -- & -- & -- & -- & 0 & -- & -- & -- & -- \\
\hline USGS & 3 & $<1$ & $<1$ & $<1$ & $<1$ & 0 & -- & -- & -- & -- \\
\hline USGS & 8 & $<1$ & $<1$ & $<1$ & $<1$ & 8 & $<1$ & $<1$ & $<1$ & 6.0 \\
\hline USGS & 2 & $<1$ & $<1$ & $<1$ & $<1$ & 0 & -- & -- & -- & -- \\
\hline USGS & 22 & $<1$ & $<1$ & $<1$ & 1.0 & 21 & $<1$ & 3.8 & 4.0 & 8.0 \\
\hline USGS & 0 & -- & -- & -- & -- & 0 & -- & -- & -- & -- \\
\hline USGS & 94 & $<1$ & 1.3 & 1.0 & 5.0 & 12 & 1.0 & 4.7 & 4.5 & 8.7 \\
\hline USGS & 50 & $<2$ & 3.4 & 3.0 & 7.0 & 16 & 3.2 & 4.9 & 5.0 & 8.9 \\
\hline USGS & 26 & 362 & 509 & 515 & 754 & 11 & 18.6 & 39.5 & 42.3 & 62.0 \\
\hline USGS & 70 & $<1$ & 10.4 & 7.0 & 93.4 & 11 & 3.9 & 7.6 & 6.2 & 24.5 \\
\hline USGS & 18 & 4.0 & 7.7 & 6.0 & 16.0 & 10 & 5.4 & 6.9 & 7.2 & 7.9 \\
\hline USGS & 17 & 5.0 & 9.5 & 8.0 & 16.0 & 0 & -- & -- & -- & -- \\
\hline USGS & 12 & 2.7 & 26.3 & 26.0 & 53.9 & 12 & 2.1 & 15.9 & 17.6 & 27.6 \\
\hline USGS & 51 & $<1$ & 10.0 & 9.0 & 34.0 & 16 & 4.1 & 7.1 & 6.7 & 12.2 \\
\hline USGS & 15 & 8.0 & 12.4 & 12.0 & 16.0 & 0 & -- & -- & -- & -- \\
\hline USGS & 15 & 2.0 & 17.5 & 15.0 & 47.0 & 0 & -- & -- & -- & -- \\
\hline USGS & 4 & 3.0 & 6.2 & 7.0 & 8.0 & 2 & 7.6 & 9.8 & 9.8 & 12.0 \\
\hline USGS & 15 & 6.0 & 12.5 & 12.0 & 22.0 & 0 & -- & -- & -- & -- \\
\hline USGS & 15 & 5.0 & 19.5 & 20.0 & 32.0 & 0 & -- & -- & -- & -- \\
\hline USGS & 71 & 4.0 & 10.2 & 10.6 & 23.0 & 35 & 5.0 & 8.9 & 7.7 & 18.6 \\
\hline USGS & 32 & 4.0 & 9.9 & 9.4 & 16.9 & 30 & 5.7 & 12.7 & 10.9 & 22.8 \\
\hline USGS & 15 & 7.0 & 16.1 & 16.0 & 27.0 & 0 & -- & -- & -- & -- \\
\hline
\end{tabular}




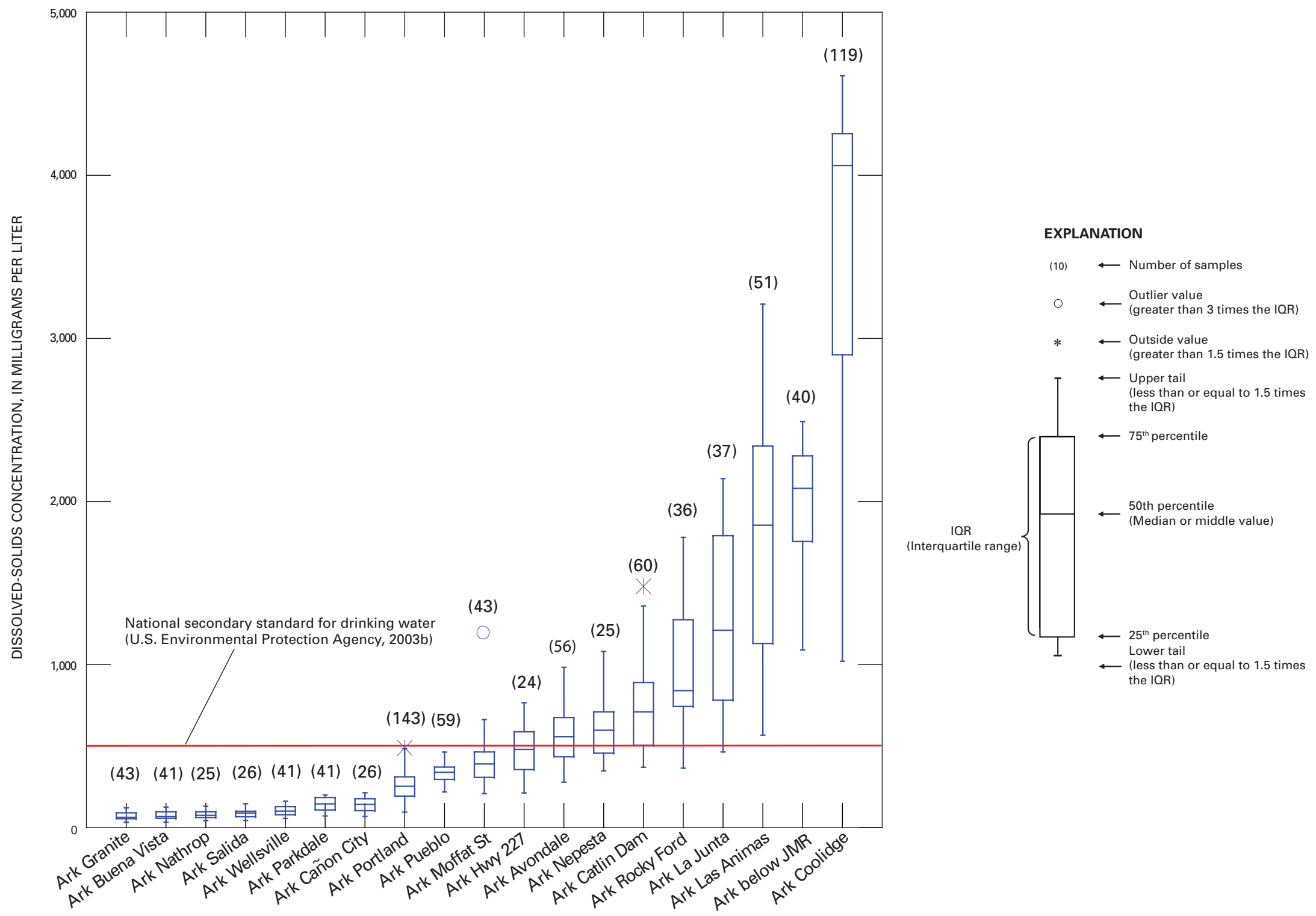

Figure 11. Spatial distribution of dissolved-solids concentrations in the Arkansas River from Granite, Colorado, to Coolidge, Kansas, $1976-2007$. 

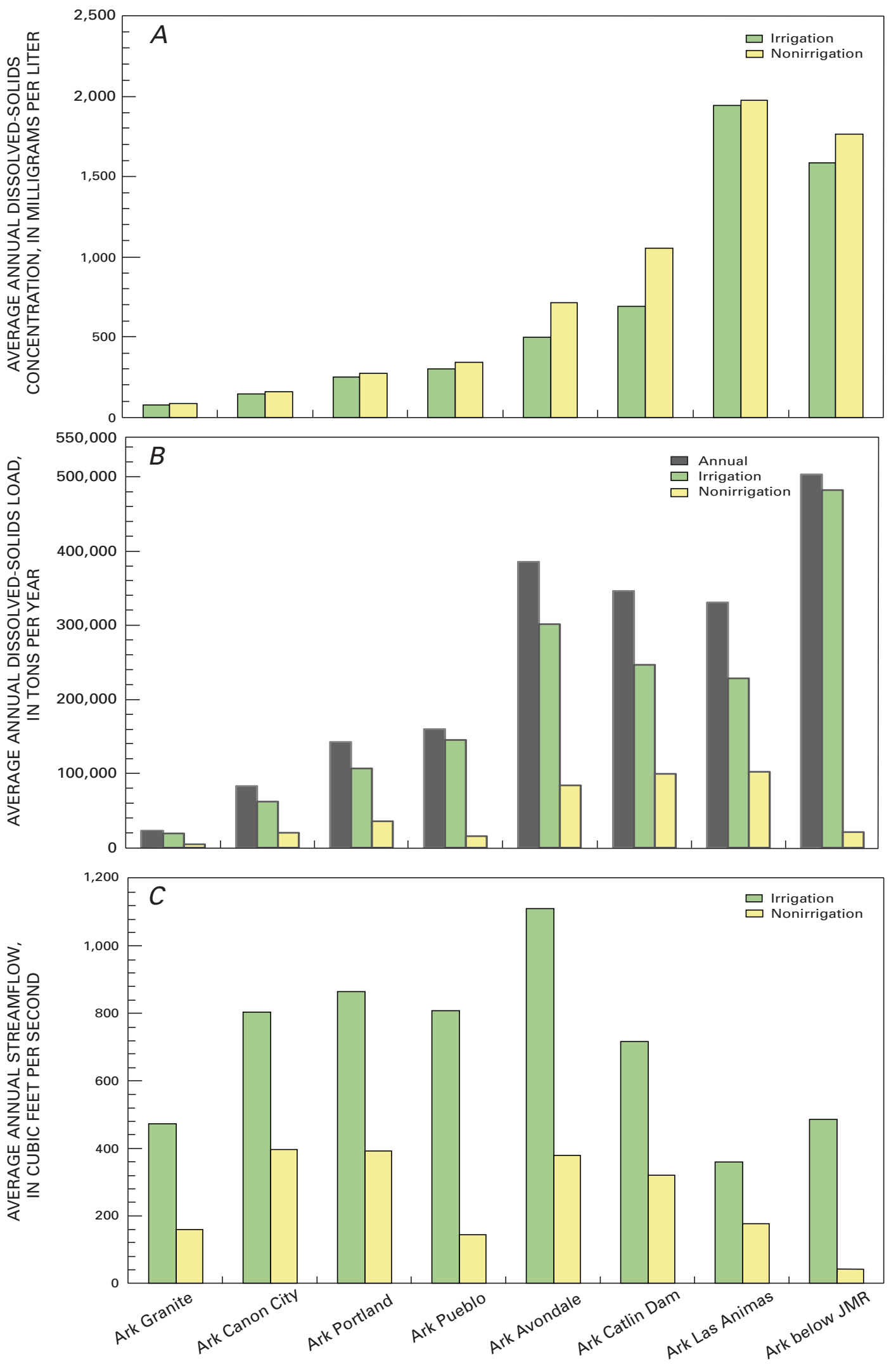

Figure 12. (A) Average annual dissolved-solids concentration, $(B)$ average annual dissolved-solids load, and $(C)$ average annual streamflow for irrigation (March-October) and nonirrigation (November-February) seasons at selected sites in the Arkansas River Basin, Colorado, 1995-2006. 
main-stem reservoirs at Ark Pueblo (below Pueblo Reservoir) and Ark below JMR (fig. 12B).

Estimates of DS loads were computed between Ark Granite and Ark below JMR for 8 main-stem Arkansas River sites, 8 tributary sites, 13 canal sites, and Pueblo Waste Water Treatment Plant (WWTP) discharge from January 1995 through December 2006. During this period, average annual DS loads in the Arkansas River increased by about 366 percent between the USGS 07096000 Arkansas River at Cañon City, Colorado (Ark Cañon City), streamgage and Ark Avondale going from about 82,700 tons per year (t/yr) at Ark Cañon City to about 385,300 t/yr at Ark Avondale (fig. 12B). Between Ark Avondale and Ark below JMR, average annual DS loads (1995-2006) in the Arkansas River increased by about 30 percent from about 385,300 t/yr at Ark Avondale to about 502,500 t/yr at Ark below JMR (fig. 12B).

Because daily SC records were not available until June 1999 at Ark Coolidge, average DS loads were computed from January 2000 through December 2006 at the main-stem Arkansas River sites to compare DS loads within the study area. Figure 13B shows that, from January 2000 through December 2006, average DS loads ranged from about 18,000 t/yr at Ark Granite to about 303,500 t/yr at Ark Avondale to about 363,800 t/yr at Ark below JMR to about 458,400 t/yr at Ark Coolidge (includes estimated DS load from Frontier Ditch). During this period, about 83 percent (Ark Avondale DS load divided by the Ark below JMR DS load multiplied by 100) of the average annual DS load at Ark below JMR and about 66 percent of the average annual DS load at Ark Coolidge can be attributed to sources upstream from Ark Avondale.

Dissolved-solids loads at main-stem sites are influenced by streamflow and large increases in DS concentration. For the most part, upstream from Ark below JMR profiles of DS loads resemble profiles of streamflow (figs. 12B, 12C, 13B, 13C), that is, DS loads increase as streamflow increases and decrease as large amounts of water are diverted from the river. However, downstream from Ark below JMR, streamflow decreases and DS loads increase due to the sharp increase in DS concentrations in the river (fig. 13A-C). Although DS concentrations at most tributary sites were relatively high in comparison to those observed in the river, the contribution of mass by the tributaries was relatively small. Fountain Creek, Huerfano River, Timpas Creek, and the Purgatoire River were the only tributaries to contribute more than 100 tons per day (t/d) (3,650 t/yr) of DS. Not only were DS loads variable spatially in the river but also temporally. From 1995 through 2006, annual DS loads at USGS 07097000 Arkansas River at Portland, Colorado (Ark Portland), ranged from about 67,100 $\mathrm{t} / \mathrm{yr}$ (2002) to 234,700 t/yr (1995), and at Ark below JMR, they ranged from 183,200 t/yr (2003) to 982,500 t/yr (1999).

\section{Dissolved-Solids Concentrations and Loads in the Upper Arkansas River}

Median DS concentrations in the Upper Arkansas River ranged from 64 milligrams per liter $(\mathrm{mg} / \mathrm{L})$ at Ark Granite to $254 \mathrm{mg} / \mathrm{L}$ at Ark Portland (table 5). Dissolved solids concentrations increased gradually between Ark Granite and USGS 07094500 Arkansas River near Parkdale, Colorado (Ark Parkdale), and then remained relatively constant in the river between Ark Parkdale and Ark Cañon City (fig. 11). However, in the 16-mile reach between Ark Cañon City and Ark Portland, median DS concentrations increased by about 78 percent (fig. 11). This increase in DS concentrations is attributed to changes in geology and chemical composition of rocks and increased irrigation return flows (Cain, 1987; Miles, 1977).

In the Upper Arkansas, DS loads were computed at the Ark Granite, Ark Cañon City, and Ark Portland sites and the Minnequa Canal headgate. The Minnequa Canal diverts water from the Arkansas River about 6 mi downstream from Ark Cañon City. From January 1995 through December 2006, average annual DS loads ranged from about 22,800 t/yr at Ark Granite to about 82,700 t/yr at Ark Cañon City to about 142,000 t/yr at Ark Portland (fig. 12B). During the same period, the Minnequa Canal diverted an average of about 18,700 t/yr of DS from the river between Cañon City and Portland. Other smaller diversions also remove water from the river but were not included in the analysis. From 1995 through 2006, more than half of the average annual DS load at Ark Portland (an average of about 78,000 t/yr of DS [(142,000 + 18,700) - 82,700]) entered the Arkansas River between Ark Cañon City and Ark Portland.

\section{Dissolved-Solids Concentrations and Loads in the Arkansas River from Pueblo Reservoir to Avondale}

In the Arkansas River between the USGS 07099400 Arkansas River above Pueblo, Colorado (Ark Pueblo), and Ark Avondale streamgages, median DS concentrations increased by about 63 percent from 340 to $553 \mathrm{mg} / \mathrm{L}$ (fig. 11 and table 5). Wild Horse Creek, Fountain Creek, Pueblo WWTP, Salt Creek, and St. Charles River discharge water into the Arkansas River between these two sites. Median DS concentrations in these waters were at least 1.5 times greater than concentrations in the river with the exception of Salt Creek, which had a median DS concentration similar to the Arkansas River (table 5).

Average annual DS loads (1995-2006) ranged from about 159,900 t/yr at Ark Pueblo to about 385,300 t/yr at Ark Avondale (fig. 12B). During this period, about 41.5 percent of the average annual DS load at Ark Avondale can be attributed to sources upstream from Ark Pueblo. The remaining 58.5 

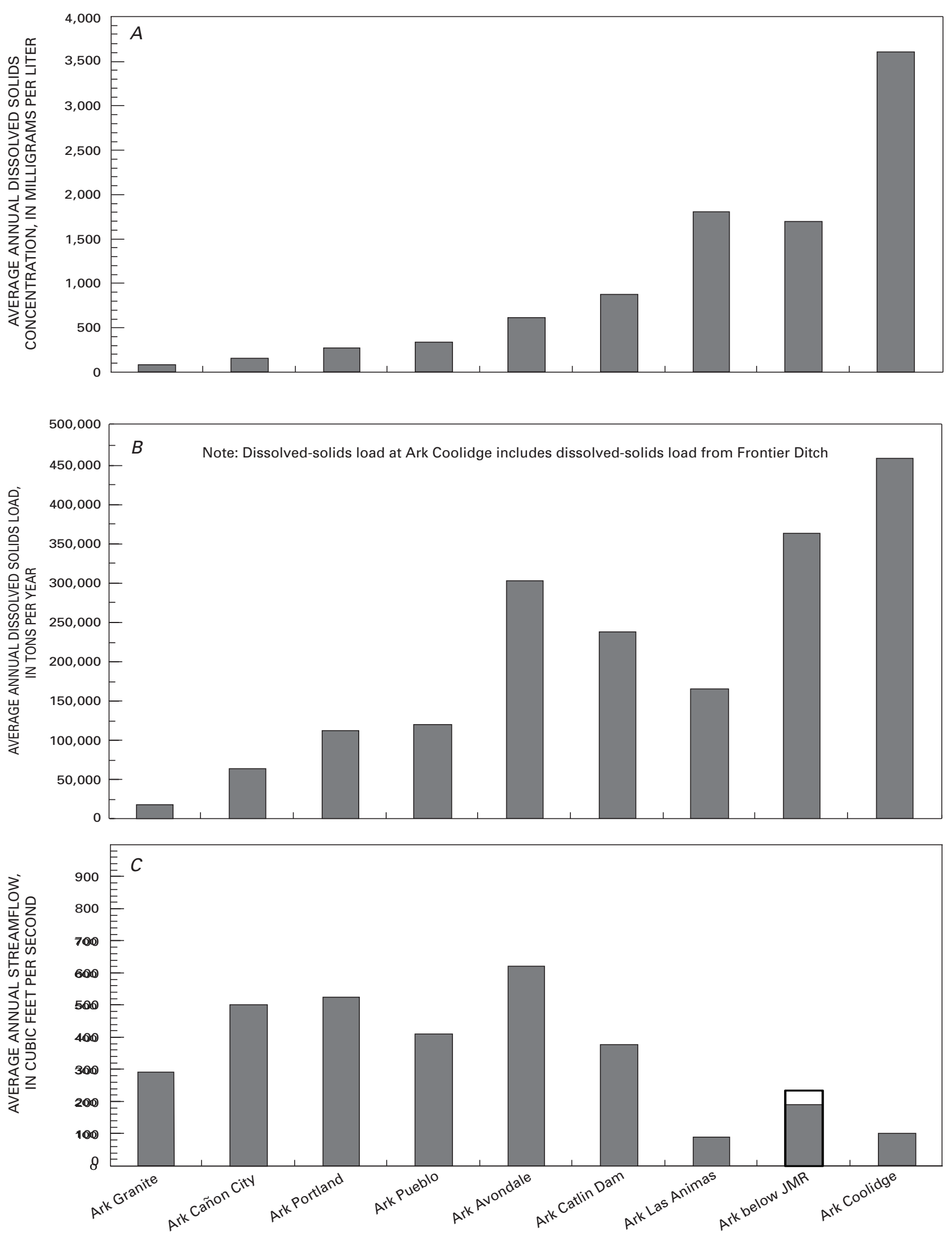

Figure 13. (A) Average annual dissolved-solids concentration, $(B)$ average annual dissolved-solids load, and $(C)$ average annual streamflow at selected sites in the Arkansas River from Granite, Colorado, to Coolidge, Kansas, 2000-2006. 
percent of the average annual DS load at Ark Avondale can be attributed to sources entering the Arkansas River between Ark Pueblo and Ark Avondale. It was estimated that about 35.9 percent of the average annual DS load at Ark Avondale (19952006) came from Fountain Creek, about 7.5 percent from St. Charles River, about 6.7 percent from Salt Creek, about 5.4 percent from Pueblo WWTP discharge, and the remaining 3 percent from inflow from ungaged tributaries or groundwater. It should be noted that daily discharge data were not available for Salt Creek. Most of the streamflow in Salt Creek comes from discharge from the steel mill near the mouth. An average daily discharge of 60 cubic feet per second $\left(\mathrm{ft}^{3} / \mathrm{s}\right)$ was assumed based on average monthly discharge in 1992, 1997, and 2002 from the steel mill (Jeff Clark, U.S. Environmental Protection Agency, Database Administrator, written commun., 2006) and instantaneous discharge measurements made when samples were collected at the site. In addition, daily DS values were not available for Salt Creek and Pueblo WWTP discharges. Daily DS loads for Salt Creek were computed by multiplying the average DS concentration in samples collected at the USGS 381530104333200 CF\&I Steel Corp. Outfall, Colorado, site (Salt Creek) by the estimated average daily flow. Daily DS loads for the Pueblo WWTP were determined by multiplying the average DS concentration in samples collected at the WWTP discharge by the daily flow measured by the City of Pueblo.

\section{Dissolved-Solids Concentrations and Loads in Fountain Creek}

Dissolved-solids concentrations were measured at USGS 07106000 Fountain Creek near Fountain, Colorado (Fnt Fountain), beginning in 2004 and at Fnt Pueblo, periodically from 1984-1993 and from December 2003 through 2007. The median DS concentration (for the common period of record December 2003 through 2007) at Fnt Fountain was 612 mg/L and at Fnt Pueblo was $792 \mathrm{mg} / \mathrm{L}$ (table 6). Table 6 shows a summary of SC values and DS, dissolved-selenium, and dissolved-uranium concentrations measured in Fountain Creek at selected sites from January 1995 through September 2007. Because very few surface-water-quality samples have been analyzed for DS in Fountain Creek, miscellaneous measurements of SC made from January 1995 through September 2007 were used to approximate the probable DS concentration profile along Fountain Creek (fig. 14). Specific-conductance values increased in Fountain Creek in the downstream direction (fig.14). Increases in SC values between USGS 07105500 Fountain Creek at Colorado Springs, Colorado (Fnt Colorado Springs) and USGS 07105530 Fountain Creek below Janitell Road below Colorado Springs, Colorado (Fnt blw Janitell) are most likely due to inflow from Janitell WWTP in the reach. Increases in SC values downstream from 07105800 Fountain Creek at Security, Colorado (Fnt Security), are likely due to a variety of sources including tributary inflow, wastewater treatment facilities (WWTF) inflow, irrigation return flow, and groundwater and surface-water interactions (fig. 14).
Dissolved-solids loads were computed for two continuous-water-quality sites along Fountain Creek (Fnt Fountain and Fnt Pueblo) for October 1999 through September 2007 due to the large amount of missing data before 1999 at the Fnt Fountain site. The average DS load, for this period, was about 88,700 t/yr at Fnt Fountain and about 105,500 t/yr at Fnt Pueblo. During this period, Fountain Creek gained about 16,800 t/yr (DS load at Fnt Pueblo minus DS load at Fnt Fountain) of DS between Fnt Fountain and Fnt Pueblo. It was determined, by dividing the change in the average annual DS load between Fnt Fountain and Fnt Pueblo (16,800 t/yr) by the average DS load at Fnt Pueblo (105,500), that about 16 percent of the average DS load at Fnt Pueblo can be attributed to sources entering the creek between Fnt Fountain and Fnt Pueblo. Most of the agriculture along Fountain Creek occurs downstream from Fnt Fountain and may contribute to some of the increase in DS loads in this reach. The remaining 84 percent of the average DS load at Fnt Pueblo (October 1999 through September 2007) can be attributed to sources upstream from Fnt Fountain.

\section{Dissolved-Solids Concentrations and Loads in the Arkan- sas River from Avondale to Coolidge}

In the Arkansas River between the Ark Avondale and Ark Coolidge sites, median DS concentrations increased from 553 to $4,060 \mathrm{mg} / \mathrm{L}$ (table 5). Not only did DS concentrations increased in the Arkansas River between Ark Avondale and Ark Coolidge (fig. 11), but also the variability in DS concentrations increased (as indicated by the difference between minimum and maximum values at a given site) with the exception of Ark below JMR where DS concentrations are probably effected by mixing in the John Martin Reservoir, which is immediately upstream from the site. A simplified schematic of the major inflows and outflows (canal diversions) between Ark Avondale and Ark Las Animas is shown in figure 15. The largest percentage increase in median DS concentrations between Pueblo Reservoir and John Martin Reservoir occurred between USGS 07120500 Arkansas River near Rocky Ford, Colorado (Ark Rocky Ford), and USGS 07123000 Arkansas River at La Junta, Colorado (Ark La Junta), where median DS concentrations increased by about 46 percent (fig. 11). Downstream from John Martin Reservoir, median DS concentrations in the Arkansas River increased by about 95 percent between Ark below JMR and Ark Coolidge (fig. 11 and table 5).

To estimate the approximate amount of ungaged inflow to the Arkansas River between Ark Avondale and Ark Las Animas, a water balance was done using average inflows and outflows from 1995 through 2006. Average inflows and outflows were only computed at stream and canal sites with continuous flow data. It should be noted that estimates of inflows and outflows and DS loads are possibly affected by errors associated with measurements of streamflow and constituent concentrations and application of regression equations to estimate DS concentrations from SC values. In the 33-mile reach between Ark Avondale and Ark Catlin Dam, the river 

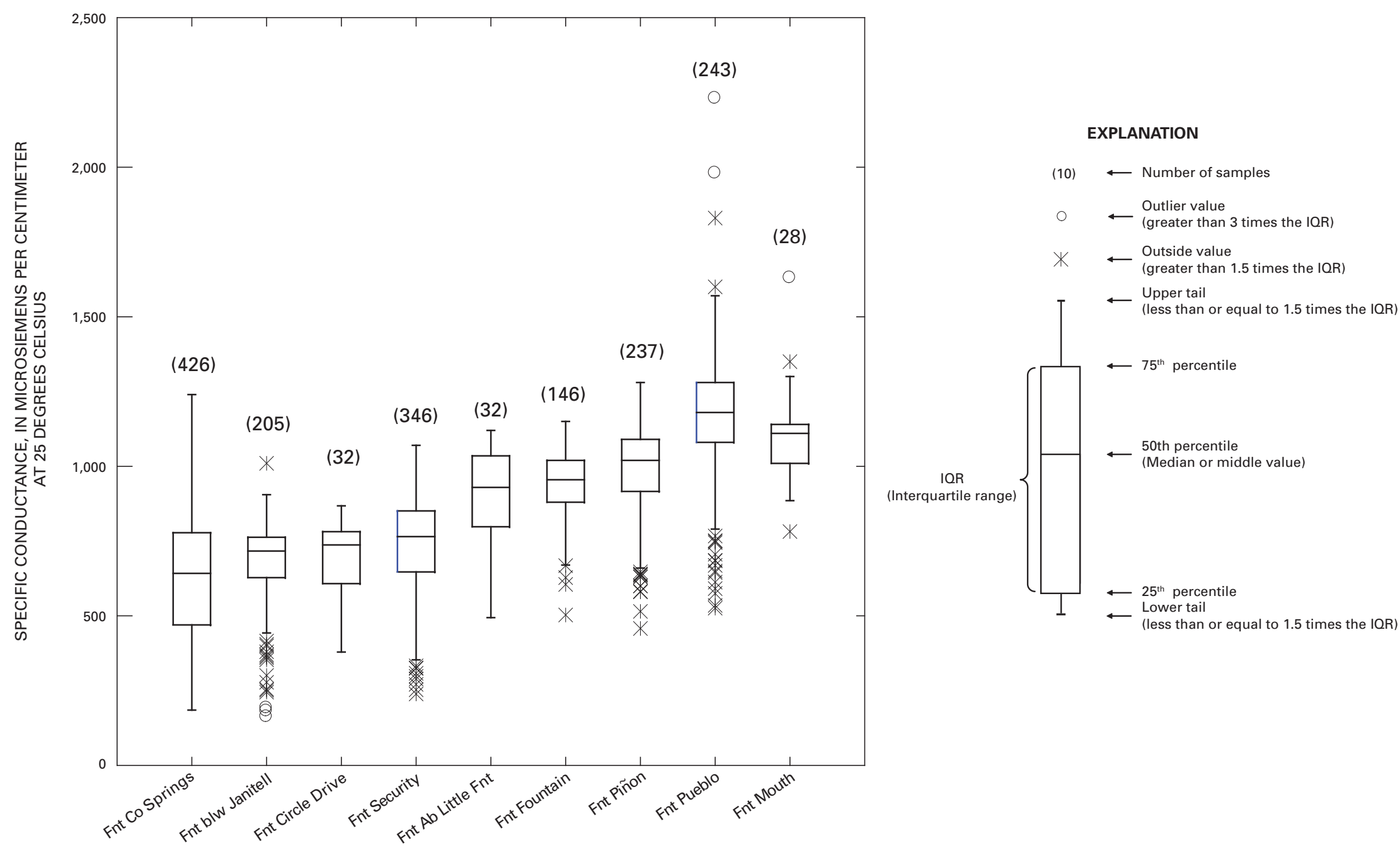

Figure 14. Spatial distribution of specific-conductance values at selected sites in Fountain Creek, Colorado, 1995-2007. 
Table 6. Summary of specific-conductance values and dissolved-solids, dissolved-selenium, and dissolved-uranium concentrations in surface-water samples at selected sites in Fountain Creek, Colorado, 1995-2007.

[USGS, U.S. Geological Survey; CDPHE, Colorado Department of Public Health and Environment; COP, City of Pueblo; N, number of samples; Min, minimum value; Max, maximum value; Med, median value; $\mu \mathrm{S} / \mathrm{cm}$, microSiemens per centimeter at $25^{\circ} \mathrm{C} ; \mathrm{mg} / \mathrm{L}$, milligram per liter; $\mu \mathrm{g} / \mathrm{L}$, microgram per liter; $<$, less than; --, no data; *, indicates that one sample concentration was reported as measured but not quantified and that the sample was not used to compute summary statistics]

\begin{tabular}{|c|c|c|c|c|c|c|c|c|c|c|c|c|c|c|c|c|c|c|c|c|c|c|}
\hline \multirow[b]{2}{*}{ Data source } & \multirow[b]{2}{*}{ Site number } & \multirow[b]{2}{*}{ Site name } & \multicolumn{5}{|c|}{ Specific conductance $(\mu \mathrm{S} / \mathrm{cm})$} & \multicolumn{5}{|c|}{ Dissolved solids (mg/L) ${ }^{1}$} & \multicolumn{5}{|c|}{ Dissolved selenium ( $\mu \mathrm{g} / \mathrm{L}$ ) } & \multicolumn{5}{|c|}{ Dissolved uranium $(\mu \mathrm{g} / \mathrm{L})$} \\
\hline & & & $\mathbf{N}$ & Min & Mean & Med & Max & $\mathbf{N}$ & Min & Mean & Med & Max & $\mathbf{N}$ & Min & Mean & Med & Max & $\mathbf{N}$ & Min & Mean & Med & Max \\
\hline USGS & 07105500 & Fnt Co Springs & 426 & 185 & 625 & 642 & 1,240 & 0 & -- & & -- & -- & 99 & $<0.5$ & 4.6 & 4.0 & 14.0 & 0 & -- & -- & -- & -- \\
\hline USGS & 07105530 & Fnt blw Janitell & 205 & 163 & 674 & 717 & 1,010 & 0 & -- & & -- & -- & $84 *$ & 1.0 & 3.9 & 4.0 & 8.0 & 0 & -- & -- & -- & -- \\
\hline USGS & 07105533 & Fnt Circle Drive & 32 & 379 & 688 & 737 & 868 & 0 & -- & & -- & -- & 0 & -- & -- & -- & -- & 1 & 3.4 & 3.4 & 3.4 & 3.4 \\
\hline USGS & 07105800 & Fnt Security & 346 & 239 & 732 & 765 & 1,070 & 0 & -- & & -- & -- & $70^{*}$ & 1.6 & 4.7 & 4.0 & 10.0 & 0 & -- & -- & -- & -- \\
\hline USGS & 07105905 & Fnt Ab Little Fnt & 32 & 494 & 892 & 930 & 1,120 & 0 & -- & & -- & -- & 29 & 3.0 & 4.5 & 4.0 & 8.0 & 0 & -- & -- & -- & -- \\
\hline USGS & 07106000 & Fnt Fountain & 146 & 503 & 933 & 955 & 1,150 & 20 & 316 & 605 & 612 & 755 & 49 & 1.5 & 6.4 & 7.0 & 10.0 & 0 & -- & -- & -- & -- \\
\hline USGS & 07106300 & Fnt Pinon & 237 & 458 & 981 & 1,020 & 1,280 & 0 & -- & & -- & -- & 56 & 1.8 & 6.1 & 6.0 & 10.0 & 0 & -- & -- & -- & -- \\
\hline CDPHE, COP & 7350 & Fnt Hwy 47 & -- & -- & -- & -- & -- & 0 & -- & & -- & -- & 20 & 2.9 & 11.6 & 7.5 & 62.8 & 0 & -- & -- & -- & -- \\
\hline USGS & 07106500 & Fnt Pueblo & 243 & 526 & 1,169 & 1,180 & 2,230 & 16 & 332 & 802 & 792 & 1,020 & 94 & 4.5 & 17.5 & 15.0 & 116.0 & 10 & 2.6 & 6.2 & 6.5 & 8.3 \\
\hline CDPHE & 7360 & Fnt 4th Street & -- & -- & & -- & -- & 0 & -- & & -- & -- & 53 & 7.1 & 19.3 & 17.0 & 77.0 & 0 & -- & -- & -- & -- \\
\hline $\begin{array}{l}\text { USGS, CDPHE, } \\
\text { COP }\end{array}$ & 7390, 381515104351900 & Fnt Mouth & 28 & 782 & 1,104 & 1,110 & 1,630 & 0 & -- & & -- & -- & 48 & 6.9 & 17.7 & 15.0 & 96.0 & 0 & -- & -- & -- & -- \\
\hline
\end{tabular}

${ }^{1}$ Summary statistics for dissolved solids were computed using data collected from December 2003 through Decemzz. 
gained an average of about $97 \mathrm{ft}^{3} / \mathrm{s}$ of flow from ungaged sources. In the 60-mile reach between Ark Catlin Dam and Ark Las Animas, the river gained an average of about $205 \mathrm{ft}^{3} / \mathrm{s}$ of flow. These gains may be attributed to irrigation-return flow (groundwater and(or) surface water) and inflow from ungaged tributaries. The average DS concentrations in the ungaged flow entering the river between Ark Avondale and Ark Catlin Dam and Ark Catlin Dam and Ark Las Animas were estimated by dividing the ungaged DS load by the ungaged inflow in each reach. Between Ark Avondale and Ark Catlin Dam, the average DS concentration in the ungaged flow entering the river was estimated to be about $1,250 \mathrm{mg} / \mathrm{L}$ and between Ark Catlin Dam and Ark Las Animas about 2,034 mg/L. These estimated DS concentrations in the ungaged flows were similar to concentrations in the alluvial wells (fig. 8) near the river and nearly twice as high as the estimated average DS concentrations in surface water diverted from the river by canals in these reaches.

In the 93-mile reach between Ark Avondale and Ark Las Animas, DS loads were computed at Ark Avondale, Ark Catlin Dam, Ark Las Animas, Ark below JMR, four tributary sites (Huerfano River, Apishapa River, Timpas Creek, and Horse Creek) and 11 major canals from 1995 through 2006. Average annual DS loads in the Arkansas River ranged from about 385,300 t/yr at Ark Avondale to about 330,300 t/yr at Ark Las Animas (fig. 12B). During the same period, between Ark Avondale and Ark Las Animas, an average of about 155,500 $\mathrm{t} / \mathrm{yr}$ of DS were input into the river by gaged tributaries, about $740,200 \mathrm{t} / \mathrm{yr}$ of DS were diverted from the river by canals, and about 529,700 t/yr of DS entered the river as ungaged flow. Roughly 22 percent of the ungaged DS load enters the river between Ark Avondale and Ark Catlin Dam and the remaining 78 percent enters the river between Ark Catlin Dam and Ark Las Animas (fig. 15). The average annual DS load at Ark below JMR was 502,500 t/yr from 1995 through 2006.

Because daily SC records were not available until June 1999 at the Ark Coolidge site, average DS loads were computed from January 2000 through December 2006 at the main-stem Arkansas River sites to compare DS loads within the study area (fig. 13). From January 2000 through December 2006, average annual DS loads ranged from 303,500 t/yr at Ark Avondale to about 363,800 t/yr at Ark below JMR to about 458,400 t/yr at Ark Coolidge (includes estimated DS load for Frontier Ditch). Frontier Ditch diverts water from the Arkansas River about 2 mi west of the Colorado-Kansas State line and from Cheyenne Creek about 0.2 mi west of the ColoradoKansas State line. Figure 16 shows a schematic diagram of the Arkansas River with a summary of average dissolved-solids loads in tons per year at selected sites and the percentage of DS load contribution by river reach for data collected from 2000 through 2006. About 66 percent of the average annual DS load (2000-2006) at Ark Coolidge can be attributed to sources upstream from Ark Avondale (fig. 16).

\section{Selenium in Groundwater in the Arkansas River Basin}

Concentrations of dissolved selenium in groundwater were available for 2,105 samples from 335 groundwater sites in the Arkansas River Basin for this analysis, including the following: (1) 166 sites in the Colorado State University's Lower Arkansas River Valley Research (LARVR) network, (2) 21 sites monitored for a study of selenium in Fountain Creek for the City of Pueblo, and (3) 148 sites in NWIS (USGS National Water Information System database) (table 4). The concentration of selenium in groundwater samples used in the analyses presented in this report (August 1970-August 2008) ranged less than 1 to more than 3,700 $\mu \mathrm{g} / \mathrm{L}$.

Seiler and others (1999), in an analysis of data collected during 1986-1995 at 26 areas in the Western United States, identified three factors common to irrigated areas with elevated selenium concentrations in groundwater and surface water: (1) proximity to a geologic source of selenium (such as Cretaceous marine shale), (2) aridity - the ratio of free-watersurface evaporation and mean annual precipitation, and (3) a topographically closed basin or sink. The Arkansas River Valley between Pueblo and the Colorado-Kansas State line is generally underlain by seleniferous shale (source of selenium), has a relatively high aridity index (Mueller and others, 1991), and is virtually a closed basin because of the reuse of water for irrigation. Mueller and others (1991) found (in their study of water quality of the middle Arkansas River Basin in Colorado and Kansas) that (1) the maximum selenium concentration in the source water (for irrigation) was $5 \mu \mathrm{g} / \mathrm{L}$, (2) in surface water downstream from the irrigated area selenium concentrations ranged from 2 to $52 \mu \mathrm{g} / \mathrm{L}$, and (3) 25 percent of the selenium concentrations downstream from the irrigated area were greater than $10 \mu \mathrm{g} / \mathrm{L}$.

Dissolved-selenium concentrations in groundwater from HSU 1 increased downgradient from median values of about $5 \mu \mathrm{g} / \mathrm{L}$ in the Upper Arkansas and Fountain Creek subbasins to $16.2 \mu \mathrm{g} / \mathrm{L}$ and $14.8 \mu \mathrm{g} / \mathrm{L}$ in the Middle Arkansas and Lower Arkansas subbasins, respectively (figs. 7 and 17). Figure 17 shows the spatial distribution of median dissolvedselenium concentrations in groundwater from HSU 1 and HSU 6 throughout the Arkansas River Basin in Colorado. Dissolved-selenium concentrations in groundwater from HSU 6 decreased downgradient with median values of 128.5, 41.4, and $24 \mu \mathrm{g} / \mathrm{L}$ in groundwater from HSU 6 in the Fountain Creek, Middle Arkansas, and Lower Arkansas subbasins, respectively (figs. 7 and 17).

\section{Selenium in Surface Water in the Arkansas River Basin}

Dissolved-selenium concentrations measured in surface water in the Arkansas River Basin (1976-2007) ranged from less than 0.5 (table 6) to $754 \mu \mathrm{g} / \mathrm{L}$ (table 5). Dissolved selenium was not detected in the Arkansas River upstream from 


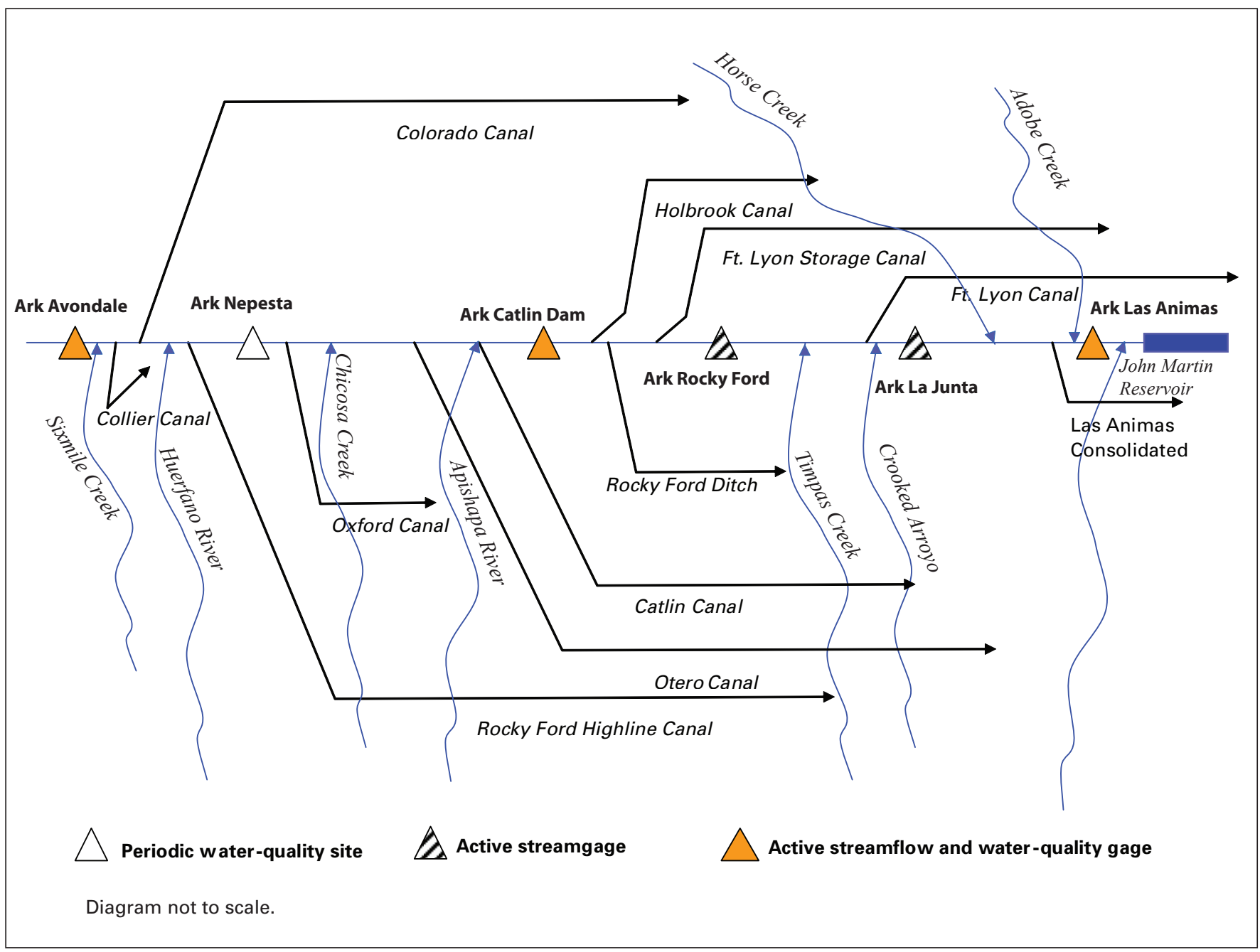

Figure 15. Map showing sample site locations and simplified schematic of tributary inflows to and major canal diversions from the Arkansas River between Avondale and Las Animas, Colorado. 

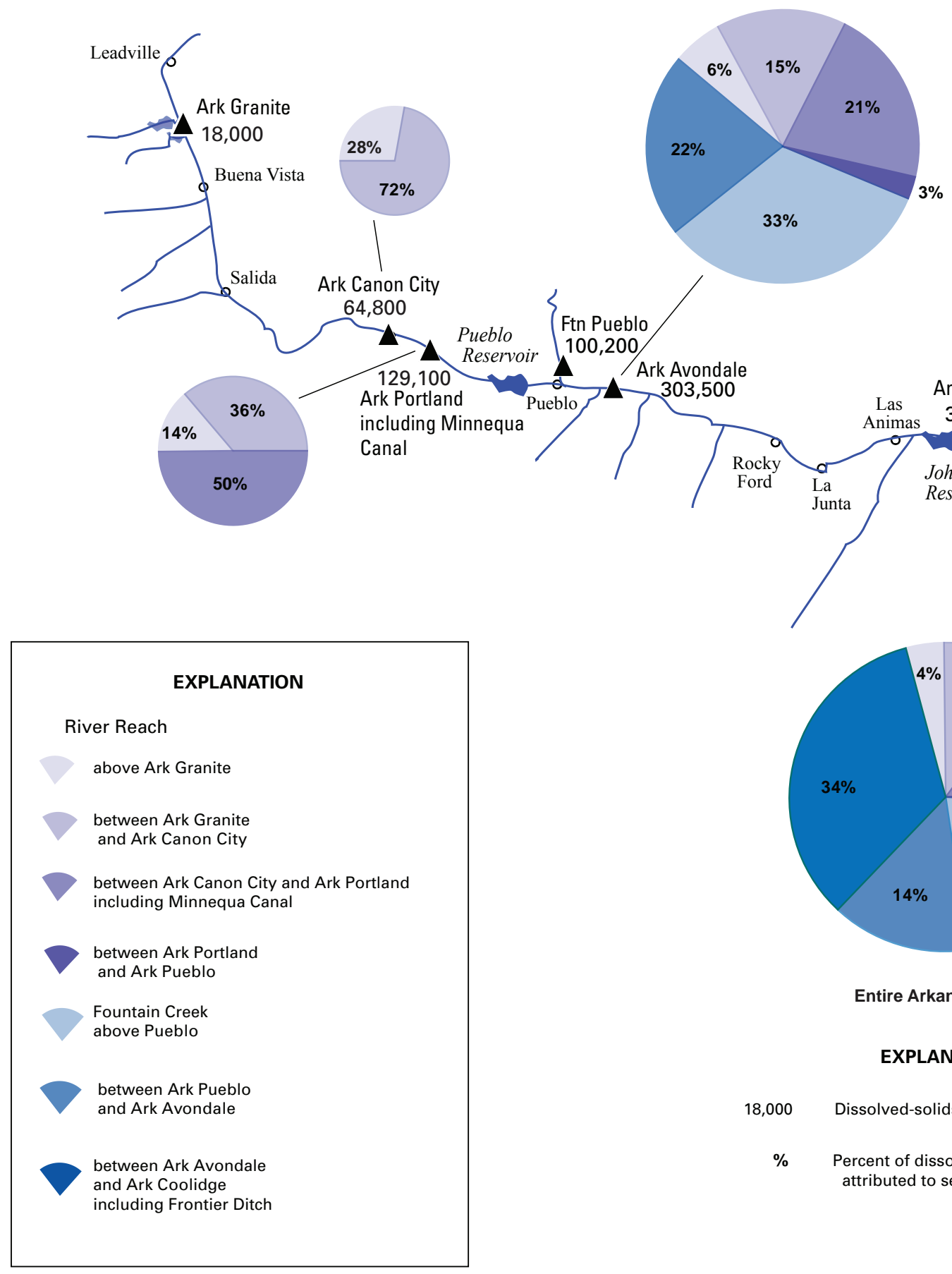

Reservoir

100,200/Ark Avondale
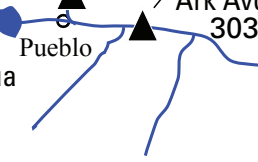

303,500
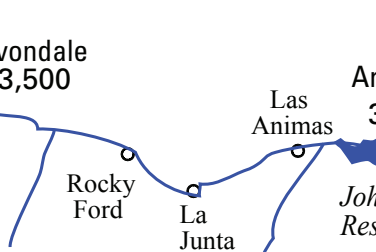

John Martin

Reservoir
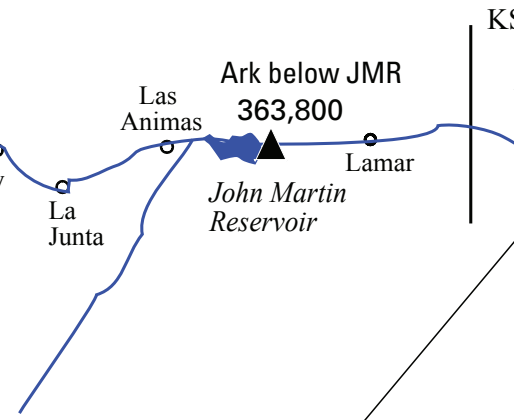

Ark Coolidge

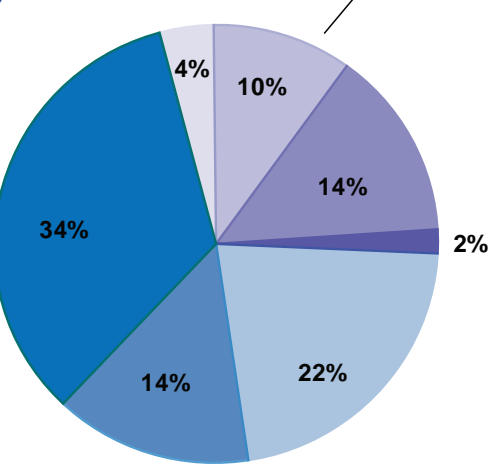

Entire Arkansas Basin

EXPLANATION

18,000 Dissolved-solids load, in tons per year

$\% \quad$ Percent of dissolved-solids load attributed to selected river reach

Figure 16. Summary of average annual dissolved-solids loads in tons per year at selected sites and percent load contribution for selected stream reaches in the Arkansas River Basin, 2000-2006. 

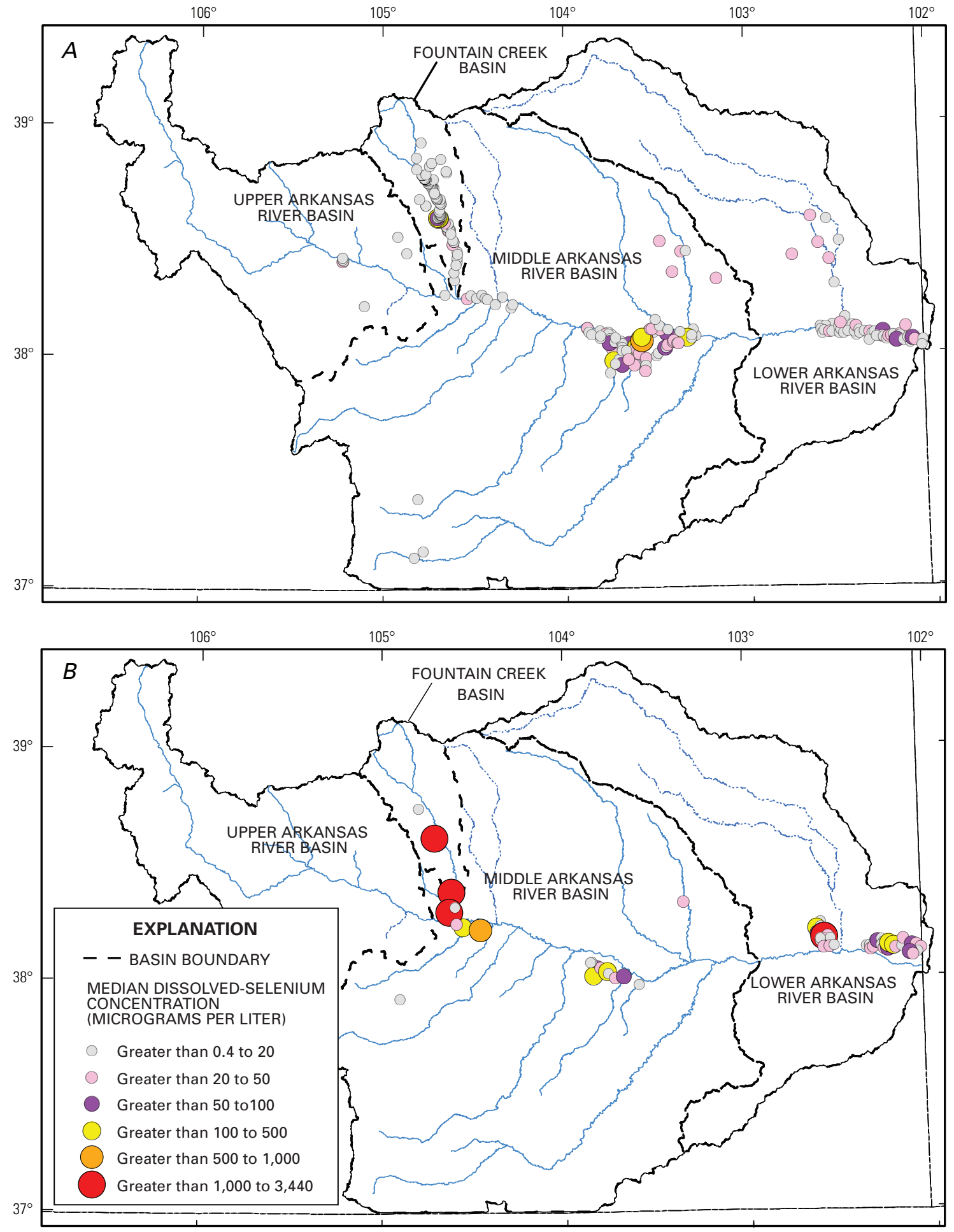

Base from U.S. Geological Survey Data, 2009, various scales Universal Transverse Mercator projection Zone13

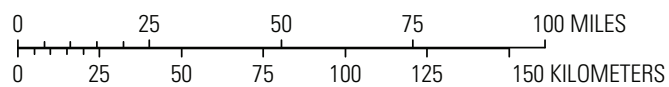

Figure 17. Median dissolved-selenium concentrations in $(A)$ unconsolidated Quaternary deposits (hydrostratigraphic unit 1) and (B) Upper Cretaceous shale and limestone (hydrostratigraphic unit 6), Arkansas River Basin, Colorado, August 1970 through August 2008. 
Ark Parkdale. Between Ark Pueblo and Ark La Junta, dissolvedselenium concentrations were generally higher in tributaries than in the Arkansas River (fig. 18A). However, between Ark La Junta and John Martin Reservoir, dissolved-selenium concentrations were generally lower in tributaries than in the Arkansas River (fig. 18A). The largest percent increases in dissolved-selenium concentrations between sites in the Arkansas River occurred between Ark Portland and Ark Pueblo and Ark Pueblo and USGS 07099970 Arkansas River at Moffat Street at Pueblo, Colorado (Ark Moffat St). Unlike DS concentrations, dissolved-selenium concentrations in the Arkansas River did not increase substantially between Ark Avondale and Ark Las Animas; and the variability in dissolved-selenium concentrations was relatively constant between Ark Avondale and Ark Las Animas (fig. 18A). The highest instantaneous dissolved-selenium loads in the Arkansas River were measured in the reach downstream from the confluence with Fountain Creek to Ark Avondale (fig. 18B).

\section{Dissolved-Selenium Concentrations in the Upper Arkansas River}

Dissolved-selenium concentrations were measured in the main-stem Arkansas River at various locations upstream from Pueblo Reservoir by the USGS as part of comprehensive water-quality studies in 1987 (Edelmann and others, 1991) and 1990-1992 (Ortiz and others, 1998). Dissolved selenium was not detected (minimum reporting level of $1 \mu \mathrm{g} / \mathrm{L}$ ) in any sample collected from the river upstream from Ark Parkdale during these studies. At the Ark Parkdale site, dissolved selenium was detected in only 1 of 22 samples (table 5) collected at a concentration of $1 \mu \mathrm{g} / \mathrm{L}$ (1981-1992). Downstream at Ark Portland, concentrations ranged from less than 1 to $5.0 \mu \mathrm{g} / \mathrm{L}$ (table 5) with a median concentration of $1.0 \mu \mathrm{g} / \mathrm{L}$ (94 samples collected from 1979-1995). Instantaneous dissolved-selenium loads were not computed for sites upstream from Pueblo Reservoir due to the large number of samples with concentrations less than the laboratory minimum reporting level.

\section{Dissolved-Selenium Concentrations and Instantaneous Loads in the Arkansas River from Pueblo Reservoir to Avondale}

In the reach between Ark Pueblo and Ark Avondale, median dissolved-selenium concentrations in the Arkansas River tripled, increasing from $3 \mu \mathrm{g} / \mathrm{L}$ at Ark Pueblo to $9 \mu \mathrm{g} / \mathrm{L}$ at Ark Avondale (fig. 18A and table 5). Median dissolvedselenium concentrations in the Arkansas River were generally lower than the median dissolved-selenium concentration (16.2 $\mu \mathrm{g} / \mathrm{L})$ in groundwater samples from HSU1 in the Middle Arkansas subbasin (fig. 7B). However, the median dissolvedselenium concentrations measured in lower Fountain Creek near the confluence with the Arkansas River and Pueblo WWTP discharge were similar to the median concentration measured in groundwater samples from HSU1 in the Middle Arkansas subbasin. Median dissolved-selenium concentrations in the river more than doubled between Ark Pueblo and Ark
Moffat St. Wild Horse Creek flows into the Arkansas River between Ark Pueblo and Ark Moffat St. Dissolved-selenium concentrations measured in samples from Wild Horse Creek ranged from 362 to $754 \mu \mathrm{g} / \mathrm{L}$ with a median of $515 \mu \mathrm{g} / \mathrm{L}$ (table 5). The highest dissolved-selenium concentrations at Ark Moffat St were measured during the lowest streamflows. Median dissolved-selenium concentrations in the Arkansas River also increased between Ark Moffat St and Ark Avondale (fig. 18A).

The Colorado Water Quality Control Commission (CWQCC) agreed to a temporary modification to the current acute and chronic State in-stream selenium standards in certain reaches of the Arkansas River, Fountain Creek, and others tributaries with existing concentrations of selenium that exceed $5 \mu \mathrm{g} / \mathrm{L}$ (Colorado Department of Public Health and Environment, 2009). The CWQCC adopted site-specific ambientand attainability-based underlying standards for selenium on several segments in the Middle and Lower Arkansas, and Fountain Creek subbasins (Colorado Department of Public Health and Environment, 2009). Modifications to the standard mostly occurred downstream from Pueblo Reservoir on the Arkansas River and selected tributaries. Modified standards ranged from just slightly more than $5 \mu \mathrm{g} / \mathrm{L}$ to as much as 710 $\mu \mathrm{g} / \mathrm{L}$ for Wild Horse Creek (Colorado Department of Public Health and Environment, 2009).

In the reach between Ark Pueblo and Ark Avondale the spatial changes observed in instantaneous-selenium loads were mostly driven by streamflow (fig. 18B). Instantaneous-selenium loads in the tributaries were rather small in comparison to the instantaneous-selenium loads in the Arkansas River (fig. 18B), because streamflows in the tributaries were generally much smaller than in the Arkansas River. However, selenium loads from some tributaries appear to effect selenium loads in the Arkansas River, particularly during lower streamflows. For example, figure $18 \mathrm{~B}$ shows an increase in the 25 th percentile and median instantaneous-selenium loads between Ark Pueblo and Ark Moffat St probably as a result of selenium loading from Wild Horse Creek. The median dissolved-selenium concentrations at Ark Pueblo and Wild Horse Creek and the average instantaneous streamflow from Wild Horse Creek were used to estimate the relative contribution from Wild Horse Creek to the selenium load at Ark Moffat St under various streamflow conditions in the Arkansas River. It was estimated that Wild Horse Creek may contribute more than 50 percent of the dissolved-selenium load in the Arkansas River at Ark Moffat St when streamflows in the Arkansas River are less than about $300 \mathrm{ft}^{3} / \mathrm{s}$. However, the effects of inflow from Wild Horse Creek at Ark Moffat St decrease as streamflows in the Arkansas River increase; and, in addition, the effects of inflow from Wild Horse Creek decrease as the Arkansas River flows downstream and other sources contribute to the selenium load.

Instantaneous dissolved-selenium loads, for the most part, more than doubled in the reach between Ark Moffat St and Ark Avondale (fig. 18B). In this reach, selenium loads from Fountain Creek, Pueblo WWTP, Salt Creek, and St. Charles River flow into the Arkansas River. Based on comparisons of median instantaneous dissolved-selenium loads 

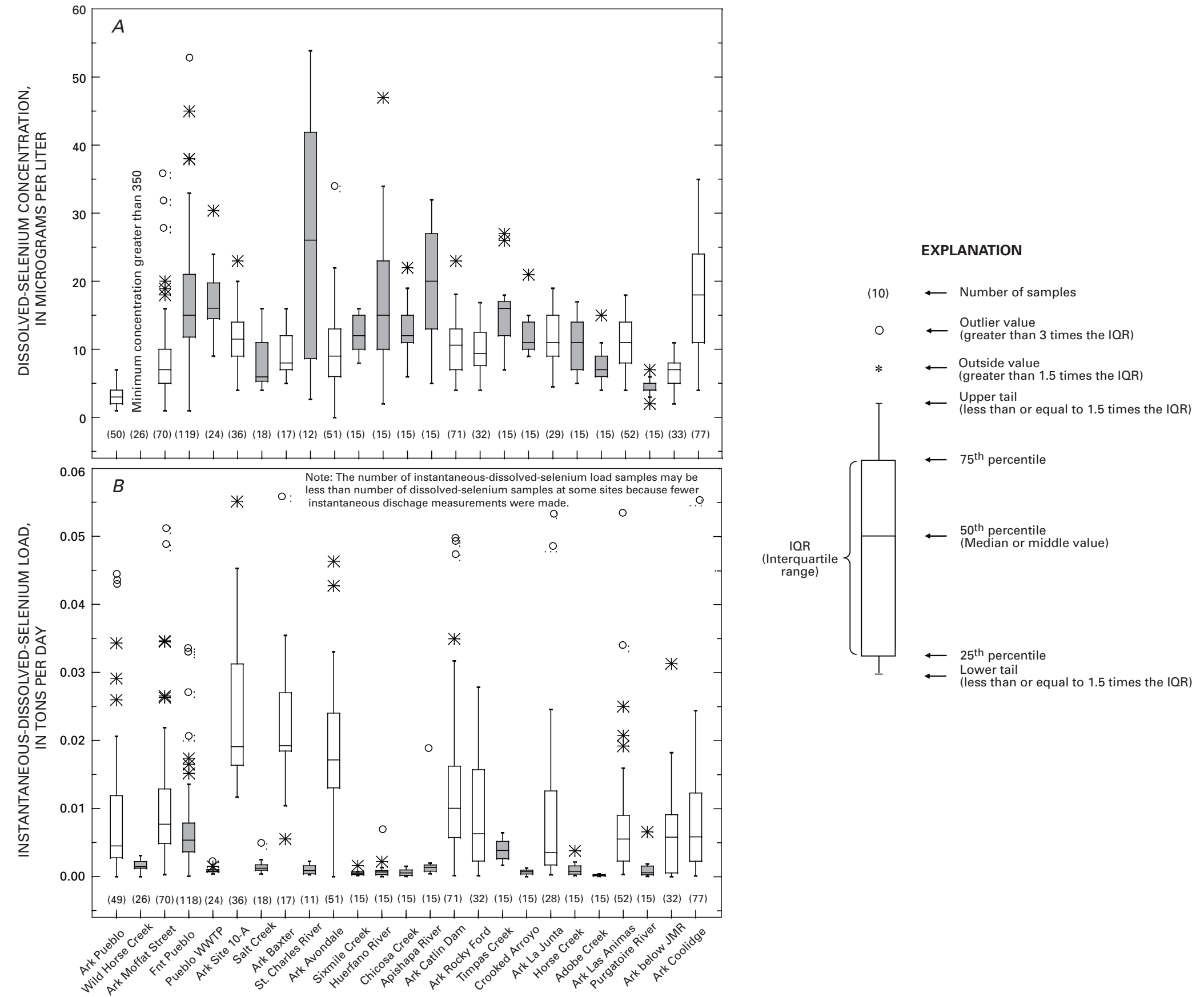

$\longleftarrow \quad \begin{aligned} & \text { Lower tail } \\ & \text { (less than or equal to } 1.5 \text { times the IQR) }\end{aligned}$

Figure 18. (A) Dissolved-selenium concentrations and $(B)$ instantaneous dissolved-selenium loads at selected sites in the Arkansas River and tributaries from Pueblo Reservoir to Coolidge, Kansas, 1976-2007. 
in the Arkansas River and tributaries between Ark Moffat St and Ark Avondale, about 45 percent of the median instantaneous dissolved-selenium load at Ark Avondale can be attributed to sources upstream from Ark Moffat St, about 31 percent to Fountain Creek inflow, about 4 percent to Pueblo WWTP inflow, and the remaining 20 percent of the median instantaneous dissolved-selenium load at Ark Avondale can be attributed to other tributary inflow (Salt Creek and St. Charles River) and additional ungaged sources. The highest instantaneous dissolved-selenium loads in the Arkansas River were measured in the reach downstream from the confluence with Fountain Creek to Ark Avondale (fig. 18B).

\section{Dissolved-Selenium Concentrations and Instantaneous Loads in Fountain Creek}

Median dissolved-selenium concentrations in Fountain Creek from Colorado Springs downstream to the mouth ranged from 4.0 to $17.0 \mu \mathrm{g} / \mathrm{L}$ from 1995 through 2007 (table 6). Generally, dissolved-selenium concentrations were lower in samples collected during high streamflows and higher in samples collected during low streamflows along Fountain Creek. The median dissolved-selenium concentration in groundwater in HSU 1 (alluvium) in the Fountain Creek subbasin (fig. 7B) was similar to median concentrations in Fountain Creek upstream from the CDPHE 7350 Fountain Creek at Highway 47 (Fnt Hwy 47) site (fig. 19 and table 6); and the median dissolved-selenium concentrations measured in lower Fountain Creek near the confluence with the Arkansas River were similar to the median concentration measured in groundwater samples from HSU1 in the Middle Arkansas subbasin (fig. 7B). Median dissolved-selenium concentrations remained constant in Fountain Creek between Fnt Co Springs to USGS 07105905 Fountain Creek above Little Fountain Creek below Fountain, Colorado (Fnt Ab Little Fnt) (fig. 19A and table 6). Between Fnt Ab Little Fnt and Fnt Fountain, median dissolved-selenium concentrations increased and then remained relatively constant to Fnt Hwy 47 (fig. 19A and table 6). In the reach between Fnt Hwy 47 and Fnt Pueblo, median dissolved-selenium concentrations in the stream doubled from 7.5 to $15.0 \mu \mathrm{g} / \mathrm{L}$; and the variability in dissolved-selenium concentrations increased at sites downstream from Fnt Hwy 47 (fig. 19A). Even though figure 19 shows an apparent increase in dissolved-selenium concentrations between Fnt Pueblo and CDPHE 7360 Fountain Creek at 4th Street Bridge (Fnt 4th Street) and subsequent decrease in dissolved-selenium concentrations between Fnt 4th Street and USGS 381515104351900 Fountain Creek at mouth near Pueblo (Fnt Mouth), differences in median dissolved-selenium concentrations were not statistically significant.

Between Fnt Co Springs and Fnt Ab Little Fnt, median dissolved-selenium concentrations in Fountain Creek were similar but streamflows varied substantially. In this reach, the lowest instantaneous dissolved-selenium loads and lowest instantaneous streamflows were measured at Fnt Co Springs; and the highest instantaneous dissolved-selenium loads and the highest streamflows were measured at Fnt Security. In the reach between Fnt Ab Little Fnt and Fnt Mouth, median instantaneous dissolved-selenium loads increased from about 0.0015 t/d (3.0 lb/d) at Fnt Ab Little Fnt to 0.0080 t/d (16 $\mathrm{lb} / \mathrm{d}$ ) at Fnt Mouth. Instantaneous dissolved-selenium loads were not computed at Fnt Hwy 47 or Fnt 4th Street, because streamflow measurements were not made by CDPHE when samples were collected. The largest percentage increase in instantaneous dissolved-selenium loads in the reach occurred between Fnt Piñon and Fnt Pueblo (fig. 19B). Median instantaneous dissolved-selenium loads in Fountain Creek between Fnt Piñon and Fnt Pueblo tripled; whereas, streamflows only increased by about 25 percent.

\section{Dissolved-Selenium Concentrations and Instantaneous Loads in the Arkansas River from Avondale to Coolidge}

Dissolved-selenium concentrations vary substantially at most sites in the Arkansas River between Ark Avondale and Ark Coolidge, generally ranging from less than or equal to 5 $\mu \mathrm{g} / \mathrm{L}$ to greater than $15 \mu \mathrm{g} / \mathrm{L}$ (fig. 18A). Unlike DS concentrations (fig. 11), dissolved-selenium concentrations in the Arkansas River did not increase substantially between Ark Avondale and Ark Las Animas; and the variability in dissolved-selenium concentrations at main-stem sites between Ark Avondale and Ark Las Animas was similar (fig. 18A). Between Ark Avondale and Ark La Junta, median dissolved-selenium concentrations measured in tributaries generally were elevated in comparison to concentrations measured in the Arkansas River (table 5 and fig. 18A). Whereas, downstream from Ark La Junta, dissolved-selenium concentrations measured in the tributaries were similar to or less than concentrations in the river (table 5 and fig. 18A). Dissolved-selenium concentrations decreased in the river between Ark Las Animas and Ark below JMR (fig. 18A). The decrease in dissolved-selenium concentrations between these two sites may be the result of chemical reduction processes that may be periodically occurring in John Martin Reservoir, particularly during winter periods (Ortiz and others, 1998). In the 66-mile reach between Ark below JMR and Ark Coolidge, median and maximum dissolved-selenium concentrations more than doubled (fig. 18A and table 5), presumably as irrigation-return flow becomes the dominant source of flow in the river. The median dissolved-selenium concentration at Ark Coolidge $(18 \mu \mathrm{g} / \mathrm{L})$ was equal to the average dissolved-selenium concentration computed for alluvial wells near the river in the reach. Unlike DS loads (figs. 12B and 13B), instantaneous-dissolved-selenium loads in the Arkansas River decreased substantially between Ark Avondale and Ark Catlin Dam and then decreased slightly or remained relatively constant to Ark Coolidge (fig. 18B). 


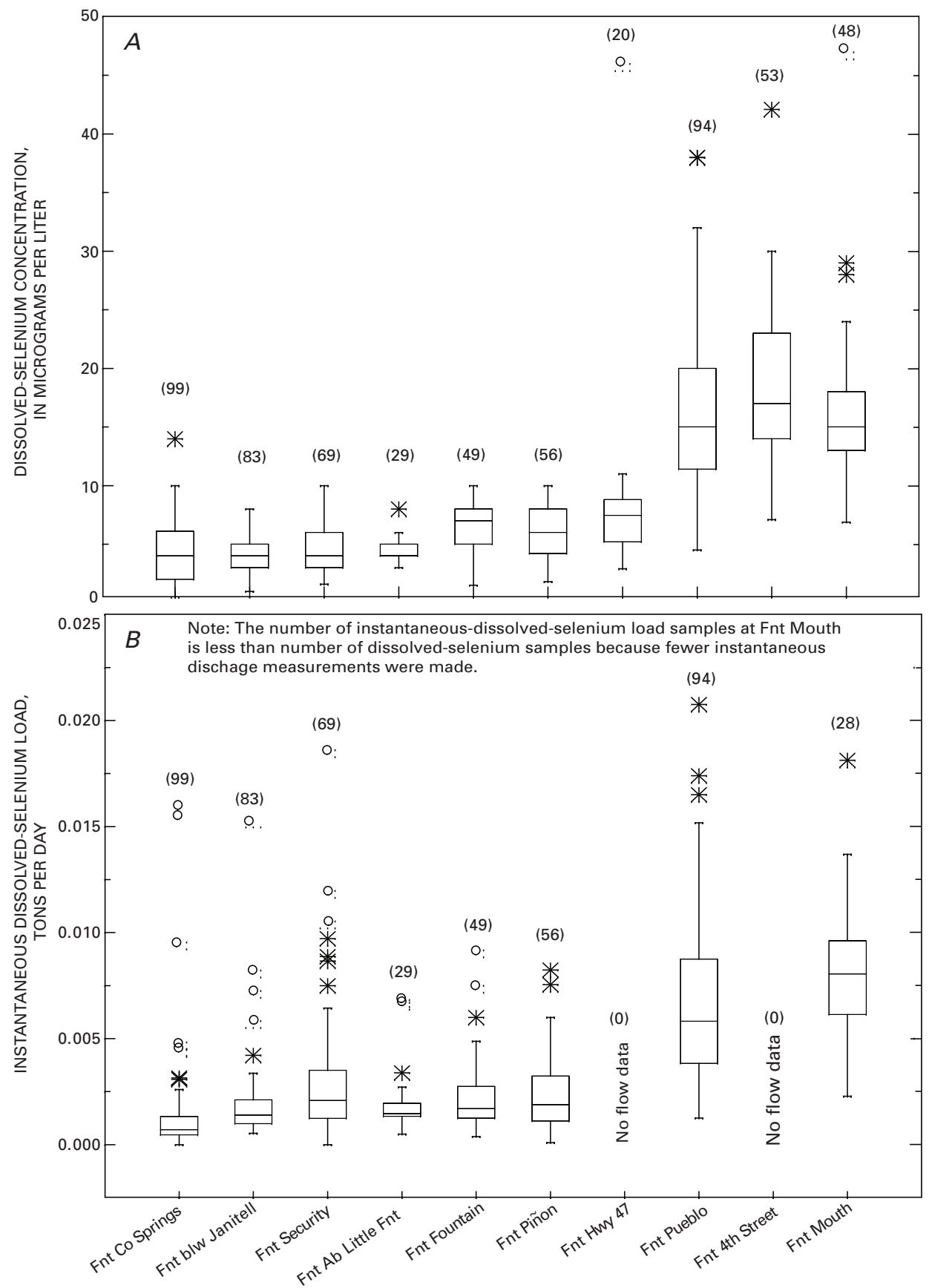

EXPLANATION

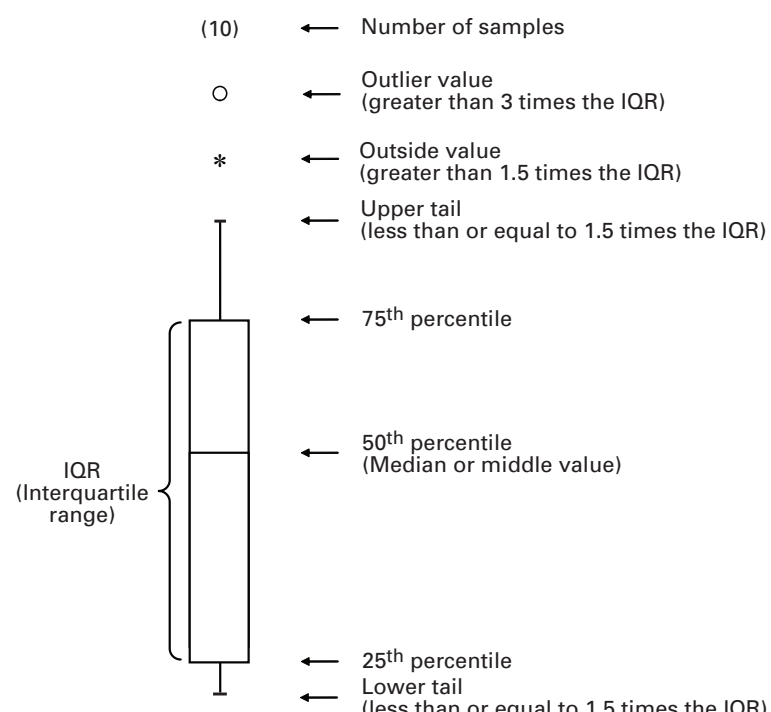

Figure 19. $(A)$ Dissolved-selenium concentrations and $(B)$ instantaneous dissolved-selenium loads at selected sites in Fountain Creek, Colorado, 1995-2007. 


\section{Dissolved Uranium in Groundwater in the Arkansas River Basin}

Uranium is a naturally occurring trace element found in groundwater in the Arkansas River Basin. Zielinski and others (1995) concluded from their evaluation of uraniferous soils in the Arkansas River Basin of southeastern Colorado that leaching of uranium from shale and from soils derived from shale, and evaporative concentration, particularly as water is recycled for irrigation, could produce concentrations of dissolved uranium in shallow groundwater that exceed national water-quality standards. The maximum contaminant level (MCL) for uranium in drinking water is $30 \mu \mathrm{g} / \mathrm{L}$ (U.S. Environmental Protection Agency, 2003a). Median dissolveduranium concentrations in groundwater are variable within and between hydrostratigraphic units (fig. 7C). Concentrations of dissolved uranium vary over about 5 orders of magnitude in groundwater from HSUs 1 and 6 (fig. 7C). Dissolved-uranium concentrations in groundwater from HSU 1 decreased downgradient from median concentrations of 9.1, 5.9, and $5.6 \mu \mathrm{g} / \mathrm{L}$ in the Upper Arkansas, Fountain Creek, and Middle Arkansas subbasins, respectively, but increased to about $11.9 \mu \mathrm{g} / \mathrm{L}$ in the Lower Arkansas subbasin (figs. 1 and 7C). Dissolved uranium concentrations in groundwater from HSU 6 exhibited a similar downgradient pattern though with smaller median values of 4.1, 2.4, 2.5, and $8.7 \mu \mathrm{g} / \mathrm{L}$ (fig. 7C) in the Upper Arkansas, Fountain Creek, Middle Arkansas, and Lower Arkansas subbasins, respectively (figs. 1 and 7C). Concentrations of dissolved uranium in groundwater from the unconsolidated Quaternary deposits (HSU 1) are larger than those in groundwater from the underlying Upper Cretaceous shale and limestone (HSU 6). Insufficient data are available to determine the cause or causes for the larger concentrations of dissolved uranium in the unconsolidated Quaternary deposits.

Areas in which groundwater in the Arkansas River Basin may contain elevated concentrations of dissolved uranium (probability of dissolved-uranium concentrations exceeding 30 $\mu \mathrm{g} / \mathrm{L}$ ) are shown in figure 20. Data used for this map were collected during August 1975 through July 1979 by the National Uranium Resource Evaluation (Smith, 1997) and are presumed to represent a contemporaneous data set. Though collected from many different aquifers throughout the Arkansas River Basin, the data are assumed to represent dissolveduranium concentrations for the uppermost aquifer, presumably the water-table aquifer. Probabilities of exceeding $30 \mu \mathrm{g} / \mathrm{L}$ dissolved uranium in groundwater were greatest in Crowley, Otero, Cheyenne, Kiowa, and Prowers Counties (fig. 20), where probabilities commonly ranged from 30 to 60 percent. These areas coincide with areas in which the lower part of the Pierre Shale and upper part of the Niobrara Formation, suspected sources of uranium, crop out or are directly overlain by the unconsolidated Quaternary deposits (fig. 2B). The primary source of groundwater recharge in the Lower Arkansas River Valley is infiltration of surface water that is diverted for irrigation. Geochemical conditions are suitable for leaching of uranium in the Lower Arkansas River Valley, because alkalinity of the surface water (primary source of groundwater recharge) increases down valley and the water is well oxygenated (Gates and others, 2009).

\section{Dissolved Uranium in Surface Water in the Arkansas River and Fountain Creek}

Dissolved-uranium concentrations measured by the USGS in surface water along the main-stem Arkansas River and selected tributaries ranged from less than 1 to $62 \mu \mathrm{g} / \mathrm{L}$ (table 5). Gates and others (2009) reported a maximum uranium concentration of $106 \mu \mathrm{g} / \mathrm{L}$ in the Arkansas River between Lamar and the Colorado-Kansas State line. Only four mainstem sites [USGS 07087200 Arkansas River at Buena Vista, Colorado (Ark Buena Vista), USGS 07093700 Arkansas River near Wellsville, Colorado (Ark Wellsville), Ark Parkdale, and Ark Portland] were sampled occasionally from 1980-1982 and(or) 1990-1992 for dissolved uranium upstream from Pueblo Reservoir. Dissolved-uranium concentrations in the Arkansas River upstream from Pueblo Reservoir ranged from less than 1 to $8.7 \mu \mathrm{g} / \mathrm{L}$ (table 5), and the highest concentrations generally were measured during the lowest streamflows. In the river upstream from Pueblo Reservoir, median and maximum dissolved-uranium concentrations increased in the downstream direction; whereas, minimum concentrations measured in the river upstream from Pueblo Reservoir were similar (equal to or less than $1 \mu \mathrm{g} / \mathrm{L}$ ) (table 5).

Boxplots of dissolved-uranium concentrations, instantaneous streamflow, and instantaneous dissolved-uranium loads in the Arkansas River at selected sites from Ark Pueblo to Ark Las Animas from 2005 through 2007 are shown in figures 21A-C. The period 2005 through 2007 was selected because most surface-water sites downstream from Pueblo Reservoir were sampled for dissolved uranium during this timeframe, and general spatial trends in surface-water dissolved-uranium concentrations (shown on figs. 21A, 21B, and 21C) are probably represented more accurately using a common period of record. However, statistical summaries presented in table 5 use all available data from 1976 through 2007. Sites upstream from Pueblo Reservoir were sampled before 2005; as a result, data from these sites are not shown on figures 21A-C.

Dissolved-uranium concentrations and the variability of dissolved-uranium concentrations measured in the Arkansas River typically increased in the downstream direction (table 5 and fig. 21A). The largest percent increase in median dissolved-uranium concentrations between main-stem sites in the river upstream from Ark Las Animas occurred between Ark Rocky Ford and Ark La Junta (fig. 21A). Median dissolveduranium concentrations measured in the river more than doubled in this reach. Dissolved-uranium concentrations are likely elevated in groundwater from HSU1 in Otero County between Ark Rocky Ford and Ark La Junta (fig. 1) in comparison to areas upstream from Ark Rocky Ford in Pueblo, Fremont, Chaffee, and Lake Counties (fig. 20). The increase in dissolved-uranium concentrations in the Arkansas River in this 


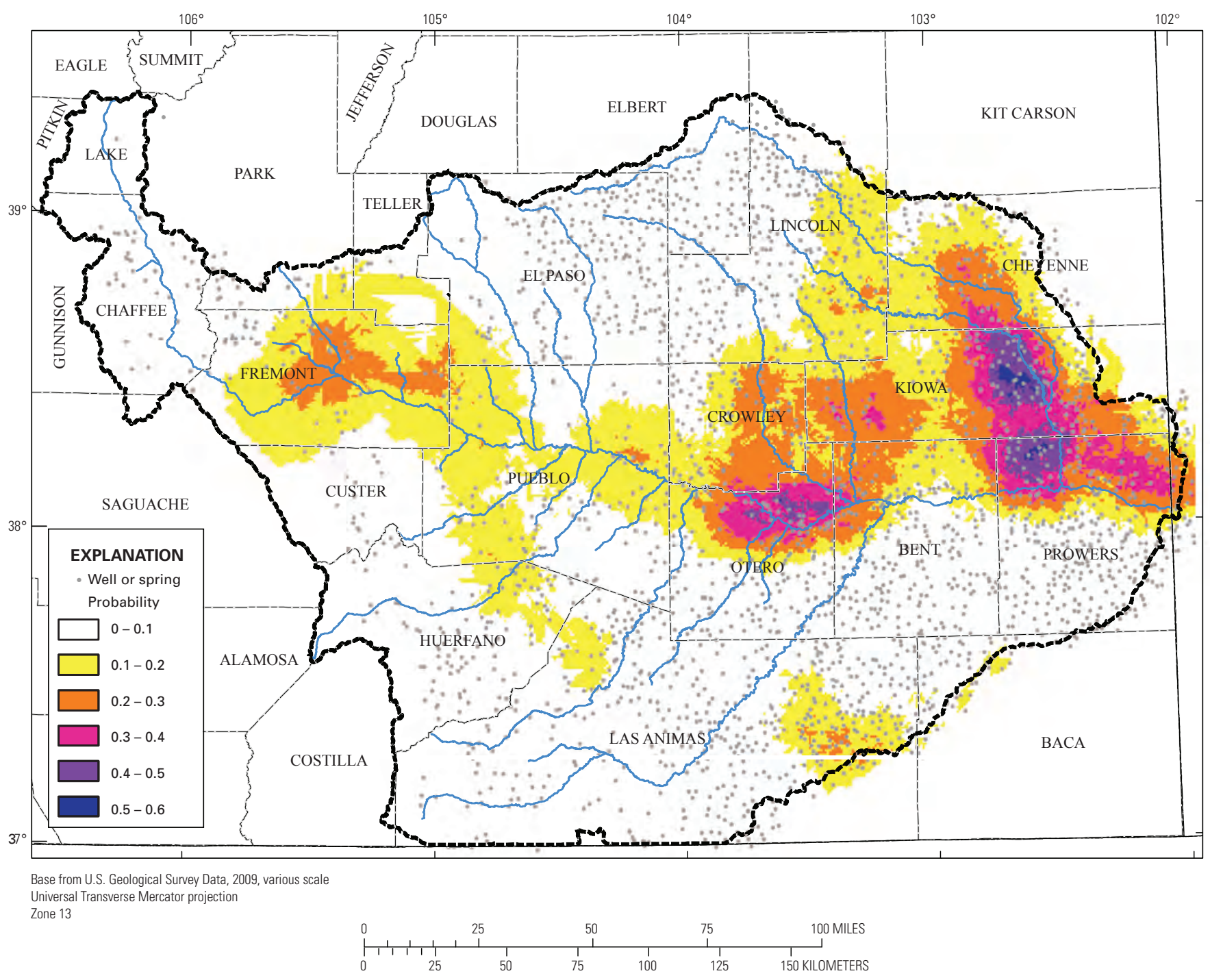

Figure 20. Probability of concentrations of dissolved uranium greater than 30 micrograms per liter in groundwater, Arkansas River Basin, Colorado, August 1975-July 1979. 

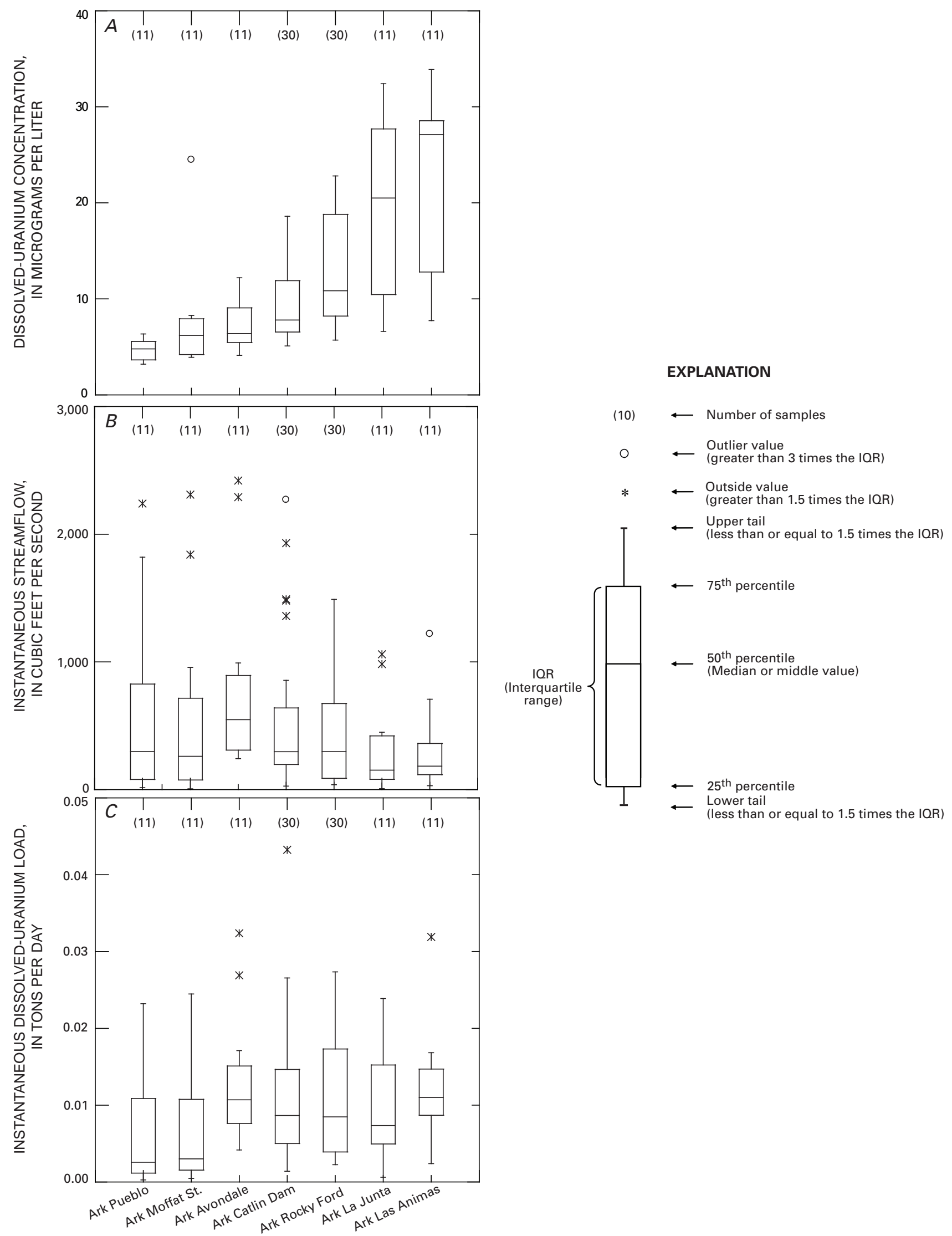

Figure 21. ( $A)$ Dissolved-uranium concentrations, $(B)$ instantaneous streamflows, and $(C)$ instantaneous dissolved-uranium loads at selected sites in the Arkansas River from Pueblo Reservoir to Las Animas, Colorado, 2005-2007. 
reach probably results from groundwater and surface-water interactions and changes in geology.

Based on data collected from 2005 through 2007, patterns in median instantaneous-dissolved-uranium loads (fig. 21C) resembled patterns in median instantaneous streamflows in the Arkansas River between Ark Pueblo and Ark Rocky Ford (fig. 21B). Downstream from Ark Rocky Ford, median instantaneous streamflows decreased (fig. 21B); whereas, median instantaneous dissolved-uranium loads remained constant or increased (fig. 21C), probably as a result of the increase in dissolved-uranium concentrations in the river described in the previous paragraphs (fig. 21A).

Dissolved-uranium concentrations were measured at two sites (USGS 07105533 Fountain Creek at Circle Drive below Colorado Springs, Colorado [Fnt Circle Drive] and Fnt Pueblo) in Fountain Creek downstream from Colorado Springs from 1995 through 2007. The dissolved-uranium concentration in the one sample collected (April 20, 1995) at Fnt Circle Drive was $3.4 \mu \mathrm{g} / \mathrm{L}$ (table 6 ), and the corresponding instantaneous-dissolved-uranium load was $2.4 \mathrm{lb} / \mathrm{d}(0.0012 \mathrm{t} / \mathrm{d})$. Dissolved-uranium concentrations measured at Fnt Pueblo ranged from 2.6 to $8.3 \mu \mathrm{g} / \mathrm{L}$ with a median concentration of $6.5 \mu \mathrm{g} / \mathrm{L}$ (table 6). Instantaneous dissolved-uranium loads at Fnt Pueblo ranged from $1.0 \mathrm{lb} / \mathrm{d}(0.0005 \mathrm{t} / \mathrm{d})$ to $17.7 \mathrm{lb} / \mathrm{d}(0.0089 \mathrm{t} / \mathrm{d})$ with a median instantaneous load of $3.5 \mathrm{lb} / \mathrm{d}(0.0018 \mathrm{t} / \mathrm{d})$. Nine of the 10 dissolved-uranium samples from Fnt Pueblo were collected during low to average streamflow conditions. In the one sample collected during high-flow (instantaneous streamflow was 10 times higher than all other samples) the maximum instantaneous dissolved-uranium load and the minimum dissolved-uranium concentration were measured.

\section{Comparison of Dissolved Solids, Selenium, and Uranium Concentrations in Groundwater and Surface Water}

Prior to the advent of irrigated agriculture in the Arkansas River Basin during the 19th century, groundwater recharge in the basin occurred primarily from infiltration of precipitation through the unsaturated zone and from infiltration of surface water from losing streams. By the mid-1880s, the waters of the Arkansas River and its tributaries were fully appropriated (Abbott, 1985), and in areas in which surface water is diverted for irrigation (such as lower Fountain Creek and the Arkansas River Valley), infiltration of irrigation water from canals and fields became a primary source of groundwater recharge. Groundwater in the alluvial aquifer (HSU 1) adjacent to the Arkansas River and its tributaries is hydraulically connected to surface water. Groundwater in the alluvial aquifer, in particular, may provide base flow and become a source of solutes to surface water or may be recharged by and possibly diluted by surface water, depending on the direction of hydraulic gradient between stream stage and groundwater levels.
Dissolved-solids concentrations in groundwater from HSU1 and surface water increased in the downstream direction. The largest percent increases in median DS concentrations in groundwater and surface water occurred between the Upper Arkansas and Middle Arkansas subbasins. Median DS concentrations in groundwater from HSU 1 increased from about $220 \mathrm{mg} / \mathrm{L}$ in the Upper Arkansas subbasin to 1,700 mg/L in the Middle Arkansas subbasin; an increase of more than 670 percent. Median DS concentrations in surface water increased from $64 \mathrm{mg} / \mathrm{L}$ at Ark Granite (Upper Arkansas subbasin) to $1,850 \mathrm{mg} / \mathrm{L}$ at Ark Las Animas (Middle Arkansas subbasin) (table 5); an increase of more than 2,790 percent.

Dissolved-selenium concentrations in groundwater from HSU 1 increased downgradient from median values of about $5 \mu \mathrm{g} / \mathrm{L}$ in the Upper Arkansas and Fountain Creek subbasins to $16.2 \mu \mathrm{g} / \mathrm{L}$ in the Middle Arkansas subbasin (fig. 7B). In contrast, the median dissolved-selenium concentration in groundwater from HSU 1 in the Lower Arkansas subbasin $(14.8 \mu \mathrm{g} / \mathrm{L})$ was lower than the median dissolved-selenium concentration measured in groundwater from HSU 1 in the Middle Arkansas subbasin. The median dissolved-selenium concentration in groundwater in HSU 1 in the Fountain Creek subbasin (fig. 7B) was similar to median dissolved-selenium concentrations measured in Fountain Creek upstream from the Fnt Hwy 47 site (fig. 19A and table 6); and the median dissolved-selenium concentrations measured in lower Fountain Creek near the confluence with the Arkansas River were similar to the median concentration measured in groundwater samples from HSU 1 in the Middle Arkansas subbasin (fig. 7B). Whereas, the median dissolved-selenium concentrations measured in the Arkansas River in the Middle Arkansas subbasin were generally lower than the median dissolved-selenium concentration measured in groundwater. In general, the highest instantaneous dissolved-selenium loads in the Arkansas River occurred in the reach downstream from the confluence with Fountain Creek to Ark Avondale (fig. 18B).

Unlike median dissolved-uranium concentrations in surface water, median dissolved-uranium concentrations in groundwater from HSU 1 did not increase in the downstream direction. Dissolved-uranium concentrations in groundwater from HSU 1 decreased downgradient from median values of 9.1, 5.9, and $5.6 \mu \mathrm{g} / \mathrm{L}$ in the Upper Arkansas, Fountain Creek, and Middle Arkansas subbasins, respectively, but increased to about $11.9 \mu \mathrm{g} / \mathrm{L}$ in the Lower Arkansas subbasin (figs. 1 and 7C). The median dissolved-uranium concentration measured in groundwater in the Upper Arkansas subbasin was greater than the median dissolved-uranium concentrations measured in surface water in the Upper Arkansas subbasin. Dissolved-uranium concentrations and the variability of dissolved-uranium concentrations measured in the Arkansas River typically increased in the downstream direction (table 5 and fig. 21A). The largest percent increase in median dissolved-uranium concentrations between main-stem sites in the Arkansas River upstream from John Martin Reservoir occurred between Ark Rocky Ford and Ark La Junta (fig. 21A). Median dissolved-uranium concentrations measured in the river more than doubled in this 
reach. Dissolved-uranium concentrations are likely elevated in groundwater from HSU1 in Otero County between Ark Rocky Ford and Ark La Junta (figs. 1and 20) in comparison to areas upstream from Ark Rocky Ford in Pueblo, Fremont, Chaffee, and Lake Counties. The increase in dissolved-uranium concentrations in the Arkansas River in this reach probably results from groundwater and surface-water interactions and changes in geology.

\section{Summary}

In 2007, the U.S. Geological Survey (USGS), in cooperation with City of Aurora, Colorado Springs Utilities, Colorado Water Conservation Board, Lower Arkansas Valley Water Conservancy District, Pueblo Board of Water Works, Southeastern Colorado Water Activity Enterprise, Southeastern Colorado Water Conservancy District, and Upper Arkansas Water Conservancy District, began a retrospective evaluation to characterize the occurrence and distribution of DS, dissolved-selenium, and dissolved-uranium concentrations in groundwater and surface water based on available waterquality data collected by several entities. This report summarizes and characterizes available DS, dissolved-selenium, and dissolved-uranium concentrations in groundwater and surface water for 1970-2009 and describes DS, dissolved-selenium, and dissolved-uranium loads in surface water along the main-stem Arkansas River and selected tributary and diversion sites from the headwaters near Leadville, Colo., to the USGS 07137500 Arkansas River near Coolidge, Kansas (Ark Coolidge), streamgage, a drainage area of 25,410 square miles.

Variability of DS concentrations in groundwater is large in the Arkansas River Basin, ranging from about 50 to more than 70,000 mg/L. Dissolved-solids concentrations in groundwater from Quaternary alluvial, glacial drift, and wind-laid deposits (HSU 1) increased downgradient with median values of about 220, 700, 1,700, and 3,400 mg/L in the Upper Arkansas, Fountain Creek, Middle Arkansas, and Lower Arkansas subbasins, respectively. Dissolved-solids concentrations in groundwater from Upper Cretaceous shale and limestone (HSU 6) also increased downgradient with median values of about 2,100, 2,300, and 3,700 mg/L in the Fountain Creek, Middle Arkansas, and Lower Arkansas subbasins, respectively.

Temporal variations in specific conductance values (which are directly related to DS concentrations) were investigated at selected sites in the Arkansas River from Ark Granite to Ark Coolidge. Analyses indicated that, for the most part, specific conductance values (surrogate for DS concentrations) have remained relatively constant or have decreased in the Arkansas River since about 1970.

Based on periodic data collected from 1976 through 2007, median DS concentrations in the Arkansas River ranged from about $64 \mathrm{mg} / \mathrm{L}$ at USGS 07086000 Arkansas River at Granite, Colorado (Ark Granite) to about 4,060 mg/L at Ark Coolidge representing more than a 6,000 percent increase in median DS concentrations. Dissolved-solids concentrations were higher in the Arkansas River during the nonirrigation season (November-February) than during the irrigation season (March-October). However, average annual DS loads were higher during the irrigation season than during the nonirrigation season. Average annual DS loads during the irrigation season were at least 2 times and as much as 23 times higher than average annual DS loads during the nonirrigation season with the largest differences occurring at sites located downstream from the two main-stem reservoirs at USGS 07099400 Arkansas River above Pueblo, Colorado (Ark Pueblo), (which is below Pueblo Reservoir) and USGS 07130500 Arkansas River below John Martin Reservoir, Colorado (Ark below JMR).

Average annual DS loads (1995-2006) in the Arkansas River increased by about 366 percent between the USGS 07096000 Arkansas River at Cañon City, Colorado (Ark Cañon City), and USGS 07109500 Arkansas River near Avondale, Colorado (Ark Avondale), streamgages going from an average of about 82,700 tons per year (t/yr) at Ark Cañon City to an average of about 385,300 t/yr at Ark Avondale. During the same period, between Ark Avondale and Ark below JMR, average annual DS loads in the Arkansas River increased by about 30 percent from an average of about 385,300 t/yr at Ark Avondale to an average of about 502,500 t/yr at Ark below JMR.

From January 2000 through December 2006, average annual DS loads in the Arkansas River ranged from about 18,000 t/yr at Ark Granite to about 303,500 t/yr at Ark Avondale to about 363,800 t/yr at Ark below JMR to about 458,400 t/yr at Ark Coolidge (includes estimated DS load for Frontier Ditch). During this period, about 66 percent of the average annual DS load at Ark Coolidge can be attributed to sources upstream from Ark Avondale.

The concentration of dissolved selenium in groundwater samples used in the analyses presented in this report ranged from less than 1 micrograms per liter ( $\mu \mathrm{g} / \mathrm{L}$ ) to more than $3,700 \mu \mathrm{g} / \mathrm{L}$. Dissolved selenium concentrations in groundwater from Quaternary deposits (HSU 1) increased downgradient from median values of about $5 \mu \mathrm{g} / \mathrm{L}$ in the Upper Arkansas (Arkansas River Basin upstream from Pueblo Reservoir) and Fountain Creek subbasins to $16.2 \mu \mathrm{g} / \mathrm{L}$ and $14.8 \mu \mathrm{g} / \mathrm{L}$ in the Middle Arkansas (Arkansas River Basin downstream from Pueblo Reservoir to Ark Avondale) and Lower Arkansas (Arkansas River Basin from Ark Avondale to Ark Coolidge) subbasins, respectively.

The largest percent increases in dissolved-selenium concentrations between sites in the Arkansas River occurred between USGS 07097000 Arkansas River at Portland, Colorado (Ark Portland), and Ark Pueblo and Ark Pueblo and USGS 07099970 Arkansas River at Moffat Street at Pueblo, Colorado (Ark Moffat St). Unlike DS concentrations, dissolved-selenium concentrations in the Arkansas River did not increase substantially in the downstream direction between Ark Avondale and Ark Las Animas, and the variability in dissolved-selenium concentrations was relatively constant between Ark Avondale and Ark Las Animas. Median 
dissolved-selenium concentrations in the Arkansas River in the Middle Arkansas subbasin were generally lower than the median dissolved-selenium concentration $(16.2 \mu \mathrm{g} / \mathrm{L})$ in groundwater samples from Quaternary deposits in the Middle Arkansas subbasin. However, the median dissolved-selenium concentrations measured in lower Fountain Creek near the confluence with the Arkansas River and Pueblo Waste Water Treatment Plant (WWTP) discharge were similar to the median concentration measured in groundwater samples from Quaternary deposits in the Middle Arkansas subbasin.

Instantaneous dissolved-selenium loads, for the most part, more than doubled in the reach between Ark Moffat St and Ark Avondale. Based on comparisons of median instantaneous dissolved-selenium loads in the river and tributaries between Ark Moffat St and Ark Avondale, about 45 percent of the median instantaneous dissolved-selenium load at Ark Avondale can be attributed to sources upstream from Ark Moffat St, about 31 percent to Fountain Creek, about 4 percent to Pueblo WWTP inflow, and the remaining 20 percent to other tributary inflow (Salt Creek and St. Charles River) and additional ungaged sources. The highest instantaneous dissolved-selenium loads in the Arkansas River were measured in the reach downstream from the confluence with Fountain Creek to Ark Avondale. Instantaneous dissolved-selenium loads in the Arkansas River decreased between Ark Avondale and Ark Catlin Dam and then remained relatively constant in the river to Ark Coolidge.

Concentrations of dissolved uranium vary over about 5 orders of magnitude in groundwater from Quaternary deposits and Upper Cretaceous shale and limestone. Probabilities of exceeding $30 \mu \mathrm{g} / \mathrm{L}$ of dissolved uranium (maximum contaminant level for uranium in drinking water) in groundwater were greatest in Crowley, Otero, Cheyenne, Kiowa, and Prowers Counties, where probabilities commonly ranged from 30 to 60 percent. These areas coincide with areas in which the lower part of the Pierre Shale and upper part of the Niobrara Formation, suspected sources of uranium, crop out or are directly overlain by the unconsolidated Quaternary deposits.
Dissolved-uranium concentrations and the variability of dissolved-uranium concentrations measured in the Arkansas River typically increased in the downstream direction. The largest percent increase in median dissolved-uranium concentrations between main-stem sites in the Arkansas River upstream from Las Animas occurred between USGS 07120500 Arkansas River near Rocky Ford, Colorado (Ark Rocky Ford), and USGS 07123000 Arkansas River at La Junta, Colorado (Ark La Junta). Dissolved-uranium concentrations are likely elevated in groundwater from HSU1 in Otero County between Ark Rocky Ford and Ark La Junta in comparison to areas upstream from Ark Rocky Ford in Pueblo, Fremont, Chaffee, and Lake Counties. The increase in dissolved-uranium concentrations in the Arkansas River in this reach probably results from groundwater and surface-water interactions and changes in geology.

Based on data collected from 2005 through 2007, patterns in median instantaneous-dissolved-uranium loads resembled patterns in median instantaneous streamflows in the Arkansas River between Ark Pueblo and the USGS 07120500 Arkansas River near Rocky Ford, Colorado (Ark Rocky Ford), streamgage. Downstream from Ark Rocky Ford, median instantaneous streamflows decreased; whereas, median instantaneous-dissolved-uranium loads remained constant or increased.

\section{Acknowledgments}

The authors wish to thank Bill Tyner and Janet Dash (Colorado Division of Water Resources) for providing data and information about canal diversions and groundwater-level measurements in the lower Arkansas River Basin and Nancy Keller (City of Pueblo), Karl Mauch (Colorado Department of Agriculture), Joy Labadie and Timothy Gates (Colorado State University-Fort Collins), and Philip Hegeman and Robert Griffith (Colorado Department of Public Health and Environment) for providing water-quality data for use in this report. 


\section{Selected References}

Abbott, P.O., 1985, Description of water-systems operations in the Arkansas River Basin, Colorado: U.S. Geological Survey Water-Resources Investigations Report 85-4092, 67 p.

Abbott, P. O.; Geldon, A.L.; Cain, Doug; Hall, A.P., and Edelmann, Patrick, 1983, Hydrology of Area 61, Northern Great Plains and Rocky Mountain Coal Provinces, Colorado and New Mexico: U.S. Geological Survey Water-Resources Investigations Report 83-132, 99 p.

Agricultural Chemicals and Groundwater Protection Program, 2009, accessed January 7, 2009, at http://ids-nile.engr. colostate.edu/webkit/Groundwater/Data_Explanation.html

ARCADIS, 2006, Sources and occurrence of selenium in the Arkansas River and Fountain Creek near Pueblo Colorado: ARCADIS, Highlands Ranch, Colorado, November, 10, 2006, 300 p.

Armbrustmacher, T.J., 1984, Alkaline rock complexes in the Wet Mountains area, Custer and Fremont counties, Colorado: U.S. Geological Survey Professional Paper 1269, 33 p.

Armbrustmacher, T.J., 1988, Geology and resources of thorium and associated elements in the Wet Mountains area, Fremont and Custer counties, Colorado: U.S. Geological Survey Professional Paper 1049-F, 34 p.

Ayers, R.S., and Westcot, D.W., 1985, Water quality for agriculture: Food and Agricultural Organization of the United Nations Irrigation and Drainage Paper 29 Rev. 1, accessed April 20, 2009, at http:/www.fao.org/DOCREP/003/ T0234E/T0234E00.htm\#TOC

Banta, E.R., 1985, The Dakota aquifer near Pueblo, Colorado; faults and flow patterns: U.S. Geological Survey WaterResources Investigations Report 85-4186, 23 p.

Banta, E.R., 1994, Statistical analysis of uranium-mill raffinate contamination in water wells in Lincoln Park, south-central Colorado: U.S. Geological Survey Water-Resources Investigations Report 93-4211, 11 p.

Banta, E.R., and Chafin, D.T., 1999, Ground-water hydrology and simulation of five remediation alternatives for an area affected by uranium-mill effluent near Cañon City, Colorado: U.S. Geological Survey Water-Resources Investigations Report 98-4229, 95 p.

Barker, F.B., Johnson, J.O., Edwards, K.W., and Robinson, B.P., 1965, Determination of uranium in natural waters: U.S. Geological Survey Water Supply Paper 1696-C, 25 p.

Bartolino, J.R., and Cole, J.C., 2002, Ground-water resources of the middle Rio Grande basin, New Mexico: U.S. Geological Survey Circular 1222, 132 p.
Bauder, Troy, Waskom, Reagan, Wawrzynski, Rob, Mauch, Karl, and Naugle, Greg, 2007, Agricultural chemicals and groundwater protection in Colorado-1990-2006: Colorado Water Resources Research Institute Special Report No. 16, $54 \mathrm{p}$.

Bossong, C.R., Karlinger, M.R., Troutman, B.M., and Vecchia, A.V., 1999, Overview and technical and practical aspects for use of geostatistics in hazardous-, toxic-, and radioactive-waste-site investigations: U.S. Geological Survey Water-Resources Investigations Report 98-4145, 70 p.

Brendle, D.L., 1999, Evaluation of possible human-induced effects on ground-water quality, St Charles Mesa, Colorado, 1997: U.S. Geological Survey Water-Resources Investigations Report 99-4085, 8 p.

Buckles, D.R., and Watts, K.R., 1988, Geohydrology, water quality, and preliminary simulations of ground-water flow of the alluvial aquifer in the Upper Black Squirrel Creek basin, El Paso County, Colorado: U.S. Geological Survey Water-Resources Investigations Report 88-4017, 49 p.

Burns, A.W., 1989, Calibration and use of an interactiveaccounting model to simulate dissolved solids, streamflow, and water-supply operations in the Arkansas River basin, Colorado: U.S. Geological Survey Water-Resources Investigations Report 88-4214, 116 p.

Butler, D.L., 2001, Effects of piping irrigation laterals on selenium and salt loads, Montrose Arroyo Basin, western Colorado: U.S. Geological Survey Water-Resources Investigations Report 01-4204, 14 p.

Butler, D.L., Krueger, R.P., Osmundson, B.C., Thompson, A.L., and McCall, S.K., 1991, Reconnaissance investigation of water quality, bottom sediment, and biota associated with irrigation drainage in the Gunnison and Uncompahgre River Basins and at Sweitzer Lake, west-central Colorado, 1988-89: U.S. Geological Survey Water-Resources Investigations Report 91-4103, 99 p.

Butler, D.L., and Leib, K.J., 2002, Characterization of selenium in the Lower Gunnison River Basin, Colorado, 1988-2000: U.S. Geological Survey Water-Resources Investigations Report 02-4151, 26 p.

Butler, D.L., Wright, W.G., Stewart, K.C., Osmundson, B.C., Krueger, R.P., and Crabtree, D.W., 1996, Detailed study of selenium and other constituents in water, bottom sediment, soil, alfalfa, and biota associated with irrigation drainage in the Uncompahgre Project Area and in the Grand Valley, west-central Colorado 1991-93: U.S. Geological Survey Water-Resources Investigations Report 96-4138, 136 p.

Cain, Doug, 1985, Quality of the Arkansas River and irrigation return flows in the lower Arkansas River valley, Colorado: U.S. Geological Survey Water-Resources Investigations Report 84-4273, 85 p. 
Cain, Doug, 1987, Relations of specific conductance to streamflow and selected water-quality characteristics of the Arkansas River basin, Colorado: U.S. Geological Survey Water-Resources Investigations Report 87-4041, 93 p.

Cain, Doug, and Edelmann, Patrick, 1980, Selected hydrologic data, Arkansas River basin, Pueblo and southeastern Fremont counties, Colorado, 1975-80: U.S. Geological Open-File Report 80-1185, 237 p.

Cain, Doug, and Edelmann, Patrick, 1986, A reconnaissance water-quality appraisal of the Fountain Creek alluvial aquifer between Colorado Springs and Pueblo, Colorado, including trace elements and organic constituents: U.S. Geological Survey Water-Resources Investigations Report 86-4085, 45 p.

Cain, Doug, Baldridge, Duaina, and Edelmann, Patrick, 1980a, Waste-assimilation capacity of the Arkansas River in Pueblo County, Colorado, as it relates to water-quality guidelines and stream classification: U.S. Geological Survey WaterResources Investigations Report 80-82, 104 p.

Cain, Doug, Ryan, B.J., and Emmons, P.J., 1980b, Hydrology and chemical quality of ground water in Crowley County, Colorado: U.S. Geological Survey Open-File Report 80-681, 2 sheets.

Chafin, D.T., 1995, Hydrogeology of the alluvial aquifers at the Pueblo Depot Activity near Pueblo, Colorado: U.S. Geological Survey Water-Resources Investigations Report 95-4137, $22 \mathrm{p}$.

Chafin, D.T., 1996, Effects of land use on water quality of the Fountain Creek alluvial aquifer, east-central Colorado: U.S. Geological Survey Water-Supply Paper 2381-D, 99 p.

Chafin, D.T., and Banta, E.R., 1999, Migration and geochemical evolution of ground water affected by uranium-mill effluent near Cañon City, Colorado: U.S. Geological Survey Water-Resources Investigations Report 98-4228, 62 p.

Coffin, D.L., and Horr, C.A., 1967, Geology and groundwater resources of the Big Sandy Creek Valley, Lincoln, Cheyenne, and Kiowa Counties, Colorado; with a section on chemical quality of the ground water: U.S. Geological Survey Water-Supply Paper 1843, 49 p.

Colorado Decision Support System, 2008, GIS Layer DataDivision 2-Arkansas, Division 2 layers, Irrigated land coverage for 2003 for the Lower Arkansas: Colorado Division of Water Resources and Colorado Water Conservation Board, Denver, Colo., accessed April 27, 2008, at http:// cdss.state.co.us/DNN/Basin/Arkansas/tabid/53/Default.aspx

Colorado Department of Agriculture, 1999 through 2004, Annual monitoring report, accessed January 7, 2009, at http://ids-nile.engr.colostate.edu/webkit/Groundwater/ annualreports.html
Colorado Department of Public Health and Environment, 2008, Quality assurance project plan for surface water monitoring and assessment, accessed March 3, 2009, at http://www.cdphe.state.co.us/wq/index.html

Colorado Department of Public Health and Environment, 2009, Surface water quality classifications and standards, regulation 32- classifications and numeric standards for Arkansas River Basin (amended 2/9/09, effective 3/30/09) and tables, accessed May 26, 2009, at http://www.cdphe. state.co.us/regulations/wqccregs/

Colorado Department of Public Health and Environment Water Quality Control Commission, 2009a, Colorado primary drinking water regulations, 5 CCR 1003-1, Amended 12/08/2008: Denver, Colo., 325 p. (available at $h t t p: / / w w w$. cdphe.state.co.us/regulations/wqccregs/100301primarydrin kingwater.pdf)

Colorado Department of Public Health and Environment Water Quality Control Commission, 2009b, The basic standards for groundwater, 5 CCR 1002-41, Amended

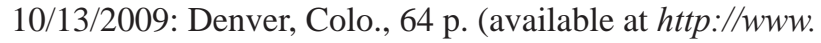
cdphe.state.co.us/regulations/wqccregs/)

Colorado Division of Water Resources, 2009, Colorado Decision Support System, accessed January-March, 2009, at http://cdss.state.co.us/DNN/default.aspx

Colorado State University, 2009a, Lower Arkansas River Valley Research, accessed January 6, 2009, at $h t t p: / / w w w$. csuarkriver.colostate.edu/index.html

Colorado State University, 2009b, Lower Arkansas River Valley Research, accessed March 25, 2009, at http://www. csuarkriver.colostate.edu/publications.html

Crouch, T.M., Cain, Doug, Abbott, P.O., Penley, R.D., and Hurr, R.T., 1984, Water-resources appraisal of the upper Arkansas River Basin from Leadville to Pueblo, Colorado: U.S. Geological Survey Water-Resources Investigations Report 82-4114, 123 p.

Crowfoot, R.M., Paillet, A.V., Ritz, G.F., Smith, M.E., Steger, R.D., and O’Neill, G.B., 1996, Water resources data Colorado, water year 1996. Volume 1. Missouri River Basin, Arkansas River Basin, and Rio Grande Basin: U. S. Geological Survey Water-Data Report CO-96-1, 512 p.

Crowfoot, R.M., Payne, W.F., and O’Neill, G.B., 2003, Water resources data Colorado, water year 2003. Volume 1. Missouri River Basin, Arkansas River Basin, and Rio Grande Basin: U. S. Geological Survey Water-Data Report CO-03-1, $577 \mathrm{p}$.

Darton, N.H., 1906, Geology and underground waters of the Arkansas Valley in eastern Colorado: U.S. Geological Survey Professional Paper 52, 90 p. 
Dash, R.G. and Ortiz, R.F., 1996, Water-quality data for the Arkansas River Basin, southeastern Colorado, 1990-93: U. S. Geological Survey Open-File Report 95-464, 137 p.

Dickinson, K.A., 1981, Geologic controls of mineralization in the Tallahassee Creek uranium district, Fremont County, Colorado: U.S. Geological Survey Open-File Report 81-735, 22 p.

Dickinson, K.A., and Hills, F.A., 1982, Oligocene volcanic rocks; possible source of uranium in epigenetic deposits in parts of Chaffee, Park, and Fremont counties, Colorado: U.S. Geological Survey Open-File Report 82-403, 35 p.

Drever, J.I., 1982, The geochemistry of natural waters: Englewood Cliffs, NJ, Prentice-Hall, 388 p.

Edelmann, Patrick, 1984, Effects of irrigating with wastewater on ground-water quality at Fort Carson Military Reservation golf course near Colorado Springs, Colorado: U.S. Geological Survey Water-Resources Investigations Report 83-4268, $32 \mathrm{p}$.

Edelmann, Patrick, and Cain, Doug, 1985, Sources of water and nitrogen to the Widefield Aquifer, southwestern El Paso County, Colorado: U.S. Geological Survey Water-Resources Investigations Report 85-4162, 81 p.

Edelmann, P., Scaplo, J.A., Colalancia, D.A., and Elson, B.B., 1991, Compilation of water-quality data for Pueblo Reservoir and the upper Arkansas River Basin, Colorado, 1985-87: U.S. Geological Survey Open-file Report 91-506, 409 p.

Environmental Systems Research, Inc., 1999-2006, ArcMap, version 9.2: Redlands, Calif.

Faires, L.M., 1993, Methods of analysis by the U.S. Geological Survey National Water Quality Laboratory-Determination of metals in water by inductively coupled plasma-mass spectrometry: U.S. Geological Survey Open-File Report 92-634, 28 p.

Felmlee, J.K., and Cadigan, R.A., 1979, Radium and uranium concentrations and associated hydrogeochemistry in ground water in southwestern Pueblo County, Colorado: U.S. Geological Survey Open-File Report 79-974, 54 p.

Fenneman, N.M., and Johnson, D.W., 1946, Physiographic divisions of the conterminous U.S.: U.S. Geological Survey, scale 1:7,000,000, 1 sheet.

Finch, W.I., 1996, Uranium provinces of North America; their definition, distribution, and models: U.S. Geological Survey Bulletin 2141, 18 p, 2 sheets.
Fishman, M.J., ed., 1993, Methods of analysis by the U.S. Geological Survey National Water Quality LaboratoryDetermination of inorganic and organic constituents in water and fluvial sediments: U.S. Geological Survey OpenFile Report 93-125, 217 p.

Fishman, M.J., and Friedman, L.C., 1985, Methods for determination of inorganic substances in water and fluvial sediments: U.S. Geological Survey Open-File Report 85-0495, 709 p.

Freeze, R.A., and Cherry, J.A., 1979, Groundwater: Englewood Cliffs, N.J., Prentice Hall, 604 p.

Garbarino, J.R., Kanagy, L.K., and Cree, M.E., 2006, Determination of elements in natural-water, biota, sediment and soil samples using collision/reaction cell inductively coupled plasma-mass spectrometry: U.S. Geological Survey Techniques and Methods, book 5, sec. B, chap. 1, 88 p.

Garbarino, J.R., 1999, Methods of analysis by the U.S. Geological Survey National Water Quality LaboratoryDetermination of dissolved arsenic, boron, lithium, selenium, strontium, thallium, and vanadium using inductively coupled plasma-mass spectrometry: U.S. Geological Survey Open-File Report 99-093, 31 p.

Gates, T.K., Cody, B.M., Donnelly, J.P., Herting, A.W., Bailey, R.T., and Price, J.M., 2009, Assessing selenium contamination in the irrigated stream-aquifer system of the Arkansas River, Colorado: Journal of Environmental Quality, v. 38, p. 2344-2356.

Gates, T.K., Garcia, L.A., and Labadie, J.W., 2006, Toward optimal water management in Colorado’s Lower Arkansas River Valley-Monitoring and modeling to enhance agriculture and environment: Colorado State University, Fort Collins, Colo., Colorado Water Resources Research Institute Completion Report no. 205, Colorado Agricultural Experiment Station Technical Report 06-10, 44 p.

Gaydos, M.W., 1980, Summary of water-quality data for selected streams in Colorado: U.S. Geological Survey Open-File Report 80-682, 152 p.

Gebert, W.A., Graczyk, D.J., and Krug, W.R., 1987, Average annual runoff in the United States, 1951-80: U.S. Geological Survey Hydrologic Investigations Atlas HA-710, 1 sheet, scale 1:7,500,000.

Geldon, A.L., 1989, Ground-water hydrology of the central Raton Basin, Colorado and New Mexico: U.S. Geological Survey Water-Supply Paper 2288, 81 p. 
Green, G.N., 1992, The digital geologic map of Colorado in ARC/INFO format: U.S. Geological Survey Open-File Report 92-507.

Griffith, Robert, 2007, Quality management plan for the collection and utilization of environmental data: Water Quality Control Division, Colorado Department of Public Health and Environment, May 2007, 28 p.

Hearne, G.A., and Litke, D.W., Ground-water flow and quality near Cañon City, Colorado: U.S. Geological Survey WaterResources Investigations Report 87-4014, 72 p.

Hearne, G. A., Lindner-Lunsford, Jaye, Cain, Doug, Watts, K. R., Robson, S. G., Tobin, R. L., Teller, R. W., Schneider, P. A., Jr., and Gearhart, M. J., 1987, Colorado ground-water quality: U.S. Geological Survey Open-File Report 87-716, 10 p.

Helsel, D.R. and Hirsch, R.M., 1992, Statistical methods in water resources: Amsterdam, Elsevier Science Publishers, $522 \mathrm{p}$.

Hem, J. D., 1985, Study and interpretation of the chemical characteristics of natural water: U.S. Geological Survey Water-Supply Paper 2254, 263 p.

Herczeg, A.L., and Edmunds, W.M., 1999, Inorganic ions as tracers, in Cook, P.G., and Herczeg, A.L., eds., Environmental tracers in subsurface hydrology: Boston, Kluwer Academic Publishers, p. 31-77.

Hill, T.P., Werner, M.A., and Horton, J.A., 1967, Chemical composition of sedimentary rocks in Colorado, Kansas, Montana, Nebraska, North Dakota, South Dakota, and Wyoming: U.S. Geological Survey Professional Paper 561, 241 p.

Hills, F.A., and Dickinson, K.A., 1982, Silver Plume Granite; possible source of uranium in sandstone uranium deposits, Tallahassee Creek and High Park areas, Fremont and Teller counties, Colorado: U.S. Geological Survey Open-File Report 82-204, 26 p.

Hon, Ken, 1984, Geology of volcanogenic uranium deposits within the Tallahassee Creek Conglomerate, Tallahassee Creek uranium district, Colorado: U.S. Geological Survey Open-File Report 84-219, 58 p.

Hurr, R.T., and Moore, J.E., 1972, Hydrogeologic characteristics of the valley-fill aquifer in the Arkansas River Valley, Bent County, Colorado: U.S. Geological Survey Hydrologic Atlas 461, 2 sheets.

Ihnat, Milan, 1989, Occurrence and distribution of selenium: CRC Press, Boca Raton, Fla., 354 p.
Jenkins, E.D., 1964, Ground water in Fountain and Jimmy Camp Valleys, El Paso County, Colorado, with a section on Computations of drawdowns caused by the pumping of wells in Fountain Valley, by R.E. Glover and E.D. Jenkins: U.S. Geological Survey Water-Supply Paper 1583, 66 p.

Jorgensen, D.G., Helgesen, J.O.; Signor, D.C.; Leonard, R.B.; Imes, J.L.; and Christenson, S.C., 1996, Analysis of regional aquifers in the central Midwest of the United States in Kansas, Nebraska, and parts of Arkansas, Colorado, Missouri, New Mexico, Oklahoma, South Dakota, Texas, and Wyoming: summary: U.S. Geological Survey Professional Paper 1414-A, p. A1-A67.

Kulp, T.R., and Pratt, L.M., 2004, Speciation and weathering of selenium in Upper Cretaceous chalk and shale from South Dakota and Wyoming, USA: Geochemica et Cosmochimica Acta., v. 68, no. 18, p. 3687-3701.

Kuzmiak, J.M., and Strickland, H.H., 1994, Bibliography of selected water-resources information for the Arkansas River basin in Colorado through 1985: U.S. Geological Survey Open-File Report 94-331, 266 p.

Lakin, H.W., and Byers, H.G., 1941, Selenium occurrence in certain soils in the United States, with a discussion of related topics — Sixth report: U.S. Department of Agriculture Technical Bulletin 783, 27 p.

Landis, E.R., 1959, Radioactivity and uranium content, Sharon Springs member of the Pierre shale, Kansas and Colorado: U.S. Geological Survey Bulletin 1046-L, p. B299-B319.

Leonard, G.J., 1984, Assessment of water resources at Fort Carson Military Reservation near Colorado Springs, Colorado: U.S. Geological Survey Water-Resources Investigations Report 83-4270, 78 p.

Lewis, M.E., 1995, Quality of water in the alluvial aquifer and tributary alluvium of the Fountain Creek valley, southwestern El Paso County, Colorado, 1991-92: U.S. Geological Survey Water-Resources Investigations Report 94-4118, 39 p.

Lewis, M.E., 1999, Simulated effects of water exchanges on streamflow and specific conductance in the Arkansas River upstream from Avondale, Colorado: U.S. Geological Survey Water-Resources Investigations Report 98-4140, 34 p.

Lewis, M.E., and Brendle, D.L., 1998, Relations of streamflow and specific-conductance trends to reservoir operations in the lower Arkansas River, southeastern Colorado: U.S. Geological Survey Water-Resources Investigations Report 97-4239, 48 p. 
Lindsey, D.A, and Clark, R.F., 1995, Copper and uranium in Pennsylvanian and Permian sedimentary rocks, northern Sangre de Cristo Range, Colorado: U.S. Geological Survey Bulletin 2116, 23 p.

Lohman, S.W., 1972, Definitions of selected ground-water terms, revisions and conceptual refinements: U.S. Geological Survey Water-Supply Paper 1988, 21 p.

Londquist, C.J., and Livingston, R.K., 1978, Water-resources appraisal of the Wet Mountain Valley, in parts of Custer and Fremont counties, Colorado: U.S. Geological Survey Scientific Investigations Report 78-1, 56 p.

Madole, R.F., VanSistine, D.P., and Michael, J.A., 2005, Distribution of Late Quaternary wind-deposited sand in eastern Colorado: U.S. Geological Survey Scientific Investigations Map 2875, 1 sheet. (Also available at $h t t p: / / p u b s . u s g s . g o v /$ $\operatorname{sim} / 2005 / 2875 /$ )

Mau, D.P., Stogner, R.W. Sr., and Edelmann, P., 2007, Characterization of stormflows and wastewater treatment-plant effluent discharges on water quality, suspended sediment, and stream morphology for Fountain and Monument Creek watersheds, Colorado, 1981-2006: U.S. Geological Survey Scientific Investigations Report 2007-5104, 77 p.

Maxey, G. B., 1964, Hydrostratigraphic units: Journal of Hydrology, v. 2, p. 124-129.

McGovern, H.E., and Jenkins, E.D., 1966, Ground water in Black Squirrel Creek Valley, El Paso County, Colorado: Hydrologic Atlas HA-236, 5 sheets.

McLaughlin, T.G., 1966, Ground water in Huerfano County, Colorado: U.S. Geological Survey Water-Supply Paper 1805, $91 \mathrm{p}$.

Meinzer, O.E., 1945, Problems of the perennial yield of artesian aquifers: Economic. Geology, v. 40, no. 3, p .159-163.

Miles, D.L., 1977, Salinity in the Arkansas Valley of Colorado: U.S. Environmental Protection Agency and Colorado State University, Interagency Agreement, EPA-IAGD4-0544, 80 p.

Miller, L.D., and Ortiz, R.F., 2007, Ground-water quality and potential effects of individual sewage disposal system effluent on ground-water quality in Park County, Colorado, 2001-2004: U.S. Geological Survey Scientific Investigations Report 2007-5220, 48 p.

Moore, D.W., Straub, A.W., Berry, M.E., Baker, M.L., and Brandt, T.R., 2002, Generalized surficial geologic map of the Pueblo 1 degree x 2 degree quadrangle, Colorado: U.S. Geological Survey, Miscellaneous Field Studies Map MF-2388, scale 1:250000.
Mueller, D.K., DeWeese, L.R., Garner, A.J., and Spruill, T.B., 1991, Reconnaissance investigation of water quality, bottom sediment, and biota associated with irrigation drainage in the middle Arkansas River basin, Colorado and Kansas, 1988-89: U.S. Geological Survey Water-Resources Investigations Report 91-4060, 84 p.

Mustard, M.H., and Cain, Doug, 1981, Hydrology and chemical quality of ground water in Kiowa County, Colorado: U.S. Geological Survey Open-File Report 81-1023, 4 sheets.

Nelson, G.A., Hurr, R.T., and Moore, J.E., 1989a, Hydrogeologic characteristics of the Valley Fill aquifer in the Arkansas River Valley, Prowers County, Colorado: U.S. Geological Survey Open-File Report 89-254, 3 sheets.

Nelson, G.A., Hurr, R.T., and Moore, J.E., 1989b, Hydrogeologic characteristics of the Valley Fill aquifer in the Arkansas River Valley, Crowley and Otero Counties, Colorado: U.S. Geological Survey Open-File Report 89-255, 3 sheets.

Nelson, G.A., Hurr, R.T., and Moore, J.E., 1989c, Hydrogeologic characteristics of the Valley Fill aquifer in the Arkansas River Valley, Pueblo County, Colorado: U.S. Geological Survey Open-File Report 89-256, 3 sheets.

Ortiz, R.F., 2004, Ground-water quality of granitic- and volcanic-rock aquifers in southeastern Park County, Colorado, July-August 2003: U.S. Geological Survey Fact Sheet 2004-3066, 6 p.

Ortiz, R.F., Lewis, M.E., and Radell, M.J., 1998, Waterquality assessment of the Arkansas River Basin, southeastern Colorado, 1990-93: U.S. Geological Survey Water-Investigations Report 97-4111, 69 p.

Pelizza, M.S., 2008, In-situ recovery of uranium: Southwest Hydrology, v. 7, no. 6, p. 28-29 and 34.

Pinyon Ecology Research Group, 2007, Interactive Colorado Plateau Precipitation Map, accessed October 13, 2009, at http://perceval.bio.nau.edu/pinyon/datamap.htm.

Pitkin, J.A., and Long, C.L., 1977, Interpretation of data from an aerial gamma-ray survey in the Cripple Creek District, Teller County, Colorado: U.S. Geological Survey Open-File Report 77-534, 12 p., 5 sheets.

Radell, M.J., Lewis, M.E., and Watts, K.R., 1994, Hydrogeologic characteristics of the alluvial aquifer and adjacent deposits of the Fountain Creek valley, El Paso County, Colorado: U.S. Geological Survey Water-Resources Investigations Report 94-4129, 4 sheets.

Robson, S.G., 1987, Bedrock aquifers in the Denver Basin, Colorado; a quantitative water-resources appraisal: U.S. Geological Survey Professional Paper 1257, 73 p. 
Robson, S.G., 1989, Alluvial and bedrock aquifers of the Denver Basin; eastern Colorado's dual ground-water resource: U.S. Geological Survey Water-Supply Paper 2302, 40 p.

Robson, S.G., and Banta, E.R., 1987, Geology and hydrology of deep bedrock aquifers in eastern Colorado: U.S. Geological Survey Water-Resources Investigations Report 85-4220, 6 sheets.

Robson, S.G., and Romero, J.C., 1981, Geologic structure, hydrology, and water quality of the Dawson aquifer in the Denver basin, Colorado: U.S. Geological Survey Hydrologic Investigations Atlas HA-643, 3 sheets, scale $1: 250,000$.

Robson, S.G., Romero, J.C., and Zawistowski, Stanley, 1981a, Geologic structure, hydrology, and water quality of the Arapahoe aquifer in the Denver basin, Colorado: U.S. Geological Survey Hydrologic Investigations Atlas HA-647, 3 sheets, scale 1:250,000.

Robson, S.G., Wacinski, Andrew, Zawistowski, Stanley, and Romero, J.C., 1981b, Geologic structure, hydrology, and water quality of the Laramie-Fox Hills aquifer in the Den_ ver basin, Colorado: U.S. Geological Survey Hydrologic Investigations Atlas HA-650, 3 sheets, scale 1:500,000.

Romero, J.C., 1992, The lower Black Squirrel, Chico, and Haynes Creek basin, E1 Paso and Pueblo Counties, Colorado: Denver, Colorado Department of Natural Resources, Division of Water Resources, Office of the State Engineer, Water Resources Investigation 92-1, 44 p.

Rona, Elizabeth, Gilpatrick, L.O., and Jeffrey, L.M., 1956, Uranium determination in sea water: American Geophysical Union Transactions, v. 37, p. 697-701.

Runkel, R.L., Crawford, C.G., and Cohn, T. A., 2004, Load estimator (LOADEST): A FORTRAN program for estimating constituent loads in streams and rivers: U.S. Geological Survey Techniques and Methods book 4, Chap. A5, 69 p.

Runnells, D.D., 1993, Inorganic chemical processes and reactions, in Alley, W.M., ed., Regional ground-water quality: New York, Van Nostrand Reinhold, p. 131-153.

Schultz, L.G., Tourtelot, H.A., Gill, J.R., and Boerngen, J.G., 1980, Composition and properties of the Pierre Shale and equivalent rocks, Northern Great Plains Region: U.S. Geological Survey Professional Paper 1064-B, 114 p.

Scott, G.R., 1969, General and engineering geology of the northern part of Pueblo, Colorado: U.S. Geological Survey Bulletin 1262, 131 p.
Scott, G.R., and Taylor, R.B., 1975, Post-Paleocene Tertiary rocks and Quaternary volcanic ash of the Wet Mountain Valley, Colorado: U.S. Geological Survey Professional Paper 868, 15 p.

Seiler, R.L., Skorupa, J.P. and Peltz, L.A., 1999, Areas susceptible to irrigation-induced selenium contamination of water and biota in the western United States: U.S. Geological Survey Circular 1180, 36 p.

Sharp, J. M., Jr., and J. K. Kyle., 1988, Ground-water processes in formation of ore deposits: in Back, W., Rosenshein, J.S., and Seaber, P.R.(eds.), Hydrology: Geological Society of America, The Geology of North America Volume O-2, p. 461-483.

Smith, S.M., 1997, National Geochemical Database: Reformatted data from the National Uranium Resource Evaluation (NURE) Hydrogeochemical and Stream Sediment Reconnaissance (HSSR) Program, Version 1.40 (2006): U.S. Geological Survey Open-File Report 97-492, available online at http://pubs.usgs.gov/of/1997/ofr-97-0492/index. html

Soister, P.E., 1968, Geologic map of the Hanover NW quadrangle, El Paso County, Colorado: U.S. Geological Survey Geologic Quadrangle 725, 1 sheet.

Southeastern Colorado Water Conservancy District, 2010, Winter Water Storage Program, accessed April 13, 2010, at http://www.secwcd.org/WinterWtr.htm

Sylvester, M.A., Kister, L.R., and Garrett, W.B., eds., 1990, Guidelines for the collection, treatment, and analysis of water samples_-U.S. Western Region field manual: Unpublished report on file in the Pueblo, Colo., Southeastern Colorado Water Science Center Office of the U.S. Geological Survey, 144 p.

SYSTAT Software, Inc., 2004, SYSTAT 11, Statistics IISoftware documentation: Richmond, California, SYSTAT Software, Inc., 657 p.

Thomas, J.C., Leib, K.J., and Mayo, J.W., 2008, Analysis of dissolved selenium loading for selected sites in the Lower Gunnison River Basin, Colorado, 1978-2005: U.S. Geological Survey Scientific Investigations Report 2007-5287, $26 \mathrm{p}$.

Topper, Ralf, Spray, K.L., Bellis, W.H., Hamilton, J.L., and Barkman, P.E., 2003, Ground water atlas of Colorado: Colorado Geological Survey Special Publication 53, 210 p.

Tourtelot, H.G., 1962, Preliminary investigation of the geologic setting and chemical composition of the Pierre Shale Great Plains Region: U.S. Geological Survey Professional Paper 390, 74 p. 
Turekian, K.K., and Wedepohl, K.H., 1961, Distribution of the elements in some major units of the earth's crust: Geological Society of America Bulletin 72, p. 175-192.

Tweto, Ogden, 1979, Geologic Map of Colorado: U.S. Geological Survey, scale 1:500,000.

U.S. Environmental Protection Agency, 2000, National water quality inventory-1998 Report, U.S. Environmental Protection Agency Report EPA-841-F-00-006, Washington D.C.

U.S. Environmental Protection Agency, 2003a, National primary drinking water regulations: United State Environmental Protection Agency, accessed April 26, 2009, at http:// www.epa.gov/safewater/contaminants/index.html\#primary

U.S. Environmental Protection Agency, 2003b, National secondary drinking water regulations: United State Environmental Protection Agency, accessed April 26, 2009, at http://www.epa.gov/safewater/contaminants/index.html\#sec

U.S. Environmental Protection Agency, 2008, STORET, accessed January 9, 2008, at http://www.epa.gov/storet/

U.S. Geological Survey, variously dated, National field manual for the collection of water-quality data: U.S. Geological Survey Techniques of Water-Resources Investigations, book 9, chaps. A1-A9, available online at http://pubs.water.usgs. gov/twri9A

U.S. Geological Survey, 1976-2006, Water resources data for Colorado, water years 1976-2005-volume 1: U.S. Geological Survey Water-Data Reports CO-76-1 to CO-05-1 (published annually).

U.S. Geological Survey, 1977, National handbook of recommended methods for water-quality acquisition: Reston, Va.: U.S. Geological Survey monograph, Office of Water Data Coordination, various pagination.

U.S. Geological Survey, 2007, Water-resources data for the United States, Water Year 2006: U.S. Geological Survey Water-Data Report WDR-US-2006, accessed April 1, 2008, at http://wdr.water.usgs.gov/

U.S. Geological Survey, 2008a, National Uranium Resource Evaluation, accessed December 11, 2008, at http://tin. er.usgs.gov/nure/water/

U.S. Geological Survey, 2008b, National Water Information System, accessed January 2008 through December 2008, at http://waterdata.usgs.gov/nwis/

U.S. Geological Survey, 2008c, Water-resources data for the United States, Water Year 2007: U.S. Geological Survey Water-Data Report WDR-US-2007, accessed April 1, 2008, at http://wdr.water.usgs.gov/
Van Alstine, R.E., 1974, Geology and mineral deposits of the Poncha Springs SE Quadrangle, Chaffee County, Colorado: U.S. Geological Survey Professional Paper 829, 19 p.

Voegeli, P.T., and Hershey, L.A, 1965, Geology and groundwater resources of Prowers County, Colorado: U.S. Geological Survey Water-Supply Paper 1772, 101 p.

Vogel, R.M., 1986, The probability plot correlation test for the normal, lognormal, and Gumbel distributional hypotheses: Water Resources Research, v. 22, no. 4, p. 587-590.

Vogel, R.M., and McMartin, D.E., 1991, Probability plot goodness-of-fit and skewness estimation procedures for the Pearson Type 3 distribution: Water Resources Research, v. 27, no. 12, p. 3149-3158.

Von Guerard, Paul, Abbott, P.O., and Nickless, R.C., 1987, Hydrology of the U.S. Army Piñon Canyon maneuver site, Las Animas County, Colorado: U.S. Geological Survey Water-Resources Investigations Report 87-4227, 117 p.

Wagner, R.J., Boulger, R.W., Jr., Oblinger, C.J., and Smith, B.A., 2006, Guidelines and standard procedures for continuous water-quality monitors-Station operation, record computation, and data reporting: U.S. Geological Survey Techniques and Methods 1-D3, 51 p. +8 attachments; accessed April 10, 2006, at http://pubs.water.usgs.gov/tm1d3

Ward, J.R., and Harr, C.A., eds., 1990, Methods for collection and processing of surface-water and bed-material samples for physical and chemical analyses: U.S. Geological Survey Open-File Report 90-140, 71 p.

Watterson, N.A., and Topper, Ralf, 2008, Lower Arkansas River alluvial aquifer—geographic, digital bibliography: Colorado Geological Survey, 1 computer disc.

Watts, K.R., 1995, Hydrogeology and simulation of flow between the alluvial and bedrock aquifers in the upper Black Squirrel Creek basin, El Paso County, Colorado: U.S. Geological Survey Water-Resources Investigations Report 94-4238, 82 p.

Watts, K.R., 2005, Hydrogeology and quality of ground water in the upper Arkansas River basin from Buena Vista to Salida, Colorado, 2000-2003: U.S. Geological Survey Scientific Investigations Report 2005-5179, 61 p.

Watts, K.R., 2006, Hydrostratigraphic Framework of the Raton, Vermejo, and Trinidad Aquifers in the Raton Basin, Las Animas County, Colorado: U.S. Geological Survey Scientific Investigations Report 2006-5129, 31 p. available at http://pubs.usgs.gov/sir/2006/5129/ 
Watts, K.R., and Ortiz, R.F., 1990, Geohydrology and groundwater quality at the Pueblo Depot activity landfill near Pueblo, Colorado: U.S. Geological Survey Water-Resources Investigations Report 89-4143, 75 p.

Weist, W.G., Jr., 1963, Water in the Dakota and Purgatoire Formations in Otero County and the southern part of Crowley County, Colorado: U.S. Geological Survey WaterSupply Paper 1669-P, 17 p.

Weist, W.G., Jr., Jenkins, E.D., and Horr, C.A., 1965, Geology and occurrence of ground water in Otero County, and the southern part of Crowley County, Colorado: U.S. Geological Survey Water-Supply Paper 1799, 90 p.

Welder, F.A., and Hurr, R.T., 1972, Appraisal of shallow ground-water resources, Pueblo Army Depot, Colorado: U.S. Geological Survey Open-File Report 72-447, 90 p.

Wenrich-Verbeek, K.J., 1980, Geochemical exploration for uranium utilizing water and stream sediments: U.S. Geological Survey Open-File Report 80-359, 36 p.

Wolock, D.M., 2003a, Estimated mean annual natural ground-water recharge in the conterminous United States: U.S. Geological Survey Open-File Report 2003-311, digital data set. available at http://water.usgs.gov/lookup/ getspatial? rech48grd
Wolock, D.M., 2003b, Base-flow index grid for the conterminous United States: U.S. Geological Survey Open-File Report 03-263, digital dataset. Available on the World Wide Web, accessed July 8, 2003. available at http://water.usgs. gov/lookup/getspatial?bfi48grd

Wolock, D.M., 2003c, Flow characteristics at U.S. Geological Survey streamgages in the conterminous United States: U.S. Geological Survey Open-File Report 03-146, digital dataset. available at http://water.usgs.gov/lookup/ getspatial?qsitesdd

Wright, W.G., and Butler, D.L., 1993, Distribution and mobilization of dissolved selenium in ground water of the irrigated Grand and Uncompahgre Valleys, western Colorado, in Allen, R.G., and Neale, C.M.U., eds., Management of irrigation and drainage systems-Integrated perspectives: American Society of Civil Engineers, Proceedings of the 1993 National Conference on Irrigation and Drainage Engineering, Park City, Utah, July 21-23, 1993, p. 770-777.

Zielinski, R.A., Asher-Bolinder, A., and Meier, A.L., 1995, Uraniferous waters of the Arkansas River valley, Colorado, U.S.A.-A function of geology and land use: Applied Geochemistry, v. 10, p. 133-144. 


\section{Appendix 1. Sources of Groundwater and Surface-Water Data Used in the Report}

\section{U.S. Geological Survey}

Water-quality data and continuous streamflow and specificconductance (SC) values were retrieved from the USGS (U.S. Geological Survey) National Water Information System (NWIS) (U.S. Geological Survey, 2008b) for surface water and groundwater in the Arkansas River Basin. In this report, however, data analyses were limited to SC, dissolved solids (DS), and dissolved selenium and uranium. Groundwaterquality data were retrieved for domestic, municipal, irrigation, livestock, and monitoring wells with emphasis placed on wells completed in the valley alluvium. Additional groundwaterquality data from the USGS National Uranium Resource Evaluation (NURE) (U.S. Geological Survey, 2008a) were included in the analyses for SC, DS, and uranium. The NURE dataset provides a synoptic view of selected constituents in groundwater, including SC and dissolved uranium. Samples were collected by the program throughout the United States; data were reformatted and documented by Smith (1997) and are available at http://pubs.usgs.gov/of/1997/ofr-97-0492/. Groundwater samples from the Arkansas River Basin were collected by the NURE program during 1975-1979.

\section{Colorado Division of Water Resources}

Surface-water-diversion data in the Arkansas River Basin (including Fountain Creek and Arkansas River tributaries) were retrieved from the Colorado Division of Water Resources' Decision Support System (CDSS) (2009). Daily diversion data from 1995-2007 were retrieved for irrigation canals and ditches, as well as, municipal, commercial, and industrial diversions.

\section{City of Pueblo}

The City of Pueblo provided surface-water and groundwater-quality data collected from 2000 through 2007 as part of the city's Arkansas River and Fountain Creek Water and Wastewater Monitoring Program (ARCADIS, 2006). As part of this program, surface-water samples were collected from the Arkansas River, Fountain Creek, and from selected tributaries and other inflows (for example, stormwater drains) to the Arkansas River and Fountain Creek in El Paso and Pueblo Counties. Groundwater samples were collected from various monitoring and irrigation wells in Pueblo County. Drilling and well installation procedures are documented in ARCADIS (2006).

Surface-water (grab samples) and groundwater samples were collected and analyzed for field properties ( $\mathrm{pH}$, conductivity, dissolved oxygen, water temperature), nutrients (nitrogen and phosphorous), sulfate, chloride, and select trace elements. Selected samples also were analyzed for DS, and total and dissolved selenium. However, samples were not analyzed for uranium. Surface-water bacteria samples for $E$. coli were collected and analyzed more frequently than the other constituents, providing the largest number of samples in the dataset.

Samples were collected by City of Pueblo personnel or contractors using the field/sampling protocols referenced in the "Surface and Groundwater Monitoring Work Plan" (ARCADIS, 2006) and analyzed at the City of Pueblo Water Reclamation Facility using U.S. Environmental Protection Agency (USEPA) certified techniques. Sampling quality assurance/quality control (QA/QC) protocols are reported by ARCADIS (2006) and laboratory protocols follow those established by USEPA for the constituents analyzed.

\section{Colorado Department of Agriculture}

Colorado Department of Agriculture provided groundwaterquality data collected from 1994 through 2009. Groundwaterquality samples were collected from a variety of well types including domestic, domestic/livestock, livestock, irrigation, domestic/irrigation, municipal, and monitoring. Pesticides were the predominant constituents analyzed in the samples; however, field properties (alkalinity, $\mathrm{pH}$, water temperature), nutrients (nitrogen and phosphorous), major cations and anions (calcium, magnesium, potassium, sodium, chloride and bicarbonate), DS, and select trace elements also were analyzed. Samples were not analyzed for selenium or uranium. The CDA's Agricultural Chemicals and Groundwater Protection Program Water Quality Database System, is a cooperative program with CDPHE and Colorado State University Cooperative Extension that began in 1992. Summaries of groundwater-quality monitoring results for pesticides and inorganic compounds, including nitrate, are available online by year and geographic location at http://ids-nile.engr.colostate.edu/webkit/ Groundwater.

Samples used in this analysis were collected from wells located within the Arkansas River valley alluvium in Pueblo, Crowley, Otero, Bent and Prowers Counties. Wells were selected for sampling based on completion in the target aquifer, depth to groundwater less than 150 feet, generally less than 50 feet, and the direction of groundwater flow (Agricultural Chemicals and Groundwater Protection Program, 2009). Samples were collected by CDA and CDPHE personnel using the field/sampling protocols developed by the Groundwater Quality Monitoring Working Group of the Colorado Nonpoint Task Force (1999-2004 Annual Monitoring Report, Colorado Department of Agriculture). Pesticide samples were primarily 
analyzed at the CDA laboratory using USEPA-approved methods for those compounds. Major ions, cations, DS and select trace elements were analyzed at the Colorado State University laboratory in Fort Collins, Colo. (Agricultural Chemicals and Groundwater Protection Program, 2009). QA/QC sampling procedures and protocols are described by Bauder and others (2007).

\section{Colorado State University - Fort Collins}

A database containing selected water-quality constituents for groundwater and surface-water samples collected by CSUFC as part of on-going research activities in the Lower Arkansas River Valley Research (LARVR), Colorado, was provided by CSUFC in August 2008. A monitoring program has been implemented in two study areas in the valley downstream from Pueblo County. Monitoring by LARVR includes measurement of groundwater levels and periodic collection of surface-water and groundwater samples for chemical analyses (http://www.csuarkriver.colostate.edu/goals.html, accessed April 27, 2009). Groundwater samples were collected from existing irrigation wells and monitoring wells installed by CSUFC. Surface-water samples were collected from the Arkansas River, selected tributaries, canals, drains, and seeps. Groundwater-quality data from CSU's LARVR program from April 2003 through August 2008 were compiled for this report.

Water samples were analyzed for a variety of constituents including field properties ( $\mathrm{pH}$, temperature, dissolved oxygen, oxidation reduction potential, and electrical conductivity), alkalinity, nitrate, select major anions and cations, total hardness, total and dissolved iron and selenium, and dissolved uranium. Additional electrical conductivity data for selected canals and Wild Horse Creek were retrieved in 2009 from the CSUFC Web site (Colorado State University, 2009a) for use in this report. Samples were not analyzed for DS. Dissolvedsolids concentrations were estimated by summing the major cations and anions as described in the "Methods" section of this report.

Samples were collected by graduate students, as part of master's thesis or doctoral work. Total and dissolved selenium samples were analyzed by South Dakota State University, Olson Biochemistry Laboratory, Brookings, South Dakota
(USEPA-certified laboratory). Total and dissolved iron, nutrients, and major anions and cations were analyzed by Ward Laboratories, Kearney, Nebraska. Field techniques for surface-water and groundwater sampling, laboratory protocols, and information on well drilling and installation were reported by Gates (Timothy Gates, Colorado State University, written commun., 2008).

\section{Colorado Department of Public Health and Environment}

Data from the USEPA Storage and Retrieval (STORET) database were accessed and downloaded in January 2008 (U.S. Environmental Protection Agency, 2008) by using hydrologic unit codes (HUC) for the Arkansas River Basin. The USEPA STORET database contains data from a number of Federal and State agencies including the USEPA, National Park Service, and CDPHE. Much of the Arkansas River Basin data in STORET are associated with mining areas in the upper part of the basin. These data were not included in this report. Only data collected by the CDPHE at selected sites on the main-stem Arkansas River and lower Fountain Creek were used in this report. To ensure reasonable comparability of data, selected constituent concentrations (for the selected CDPHE sites) were plotted and compared to data collected by USGS and City of Pueblo at nearby sites. Constituent concentrations were found to be within similar ranges and were assumed to be comparable. Sample data from 1968 through 2004 were retrieved from STORET. Samples were collected at surfacewater and groundwater monitoring sites. Some surface-water sites are collocated with USGS streamgage sites. Samples were collected throughout the Arkansas River Basin.

Constituents in STORET include field properties, total and dissolved nutrients, major ions, trace metals, radionuclides, and bacteria. Information on quality assurance can be found in the metadata files associated with STORET; however, in many cases this data field is blank. CDPHE field sampling techniques and QA/QC protocols are documented by Griffith (2007). Laboratory techniques and QA/QC protocols were provided as written communication (Robert Griffith, Colorado Department of Public Health and Environment, 2009). 


\section{Appendix 2. Temporal Variations in Instantaneous Specific-Conductance Values and Streamflow at Selected Surface-Water Sites in the Arkansas River Basin, Colorado, 1960-2009}
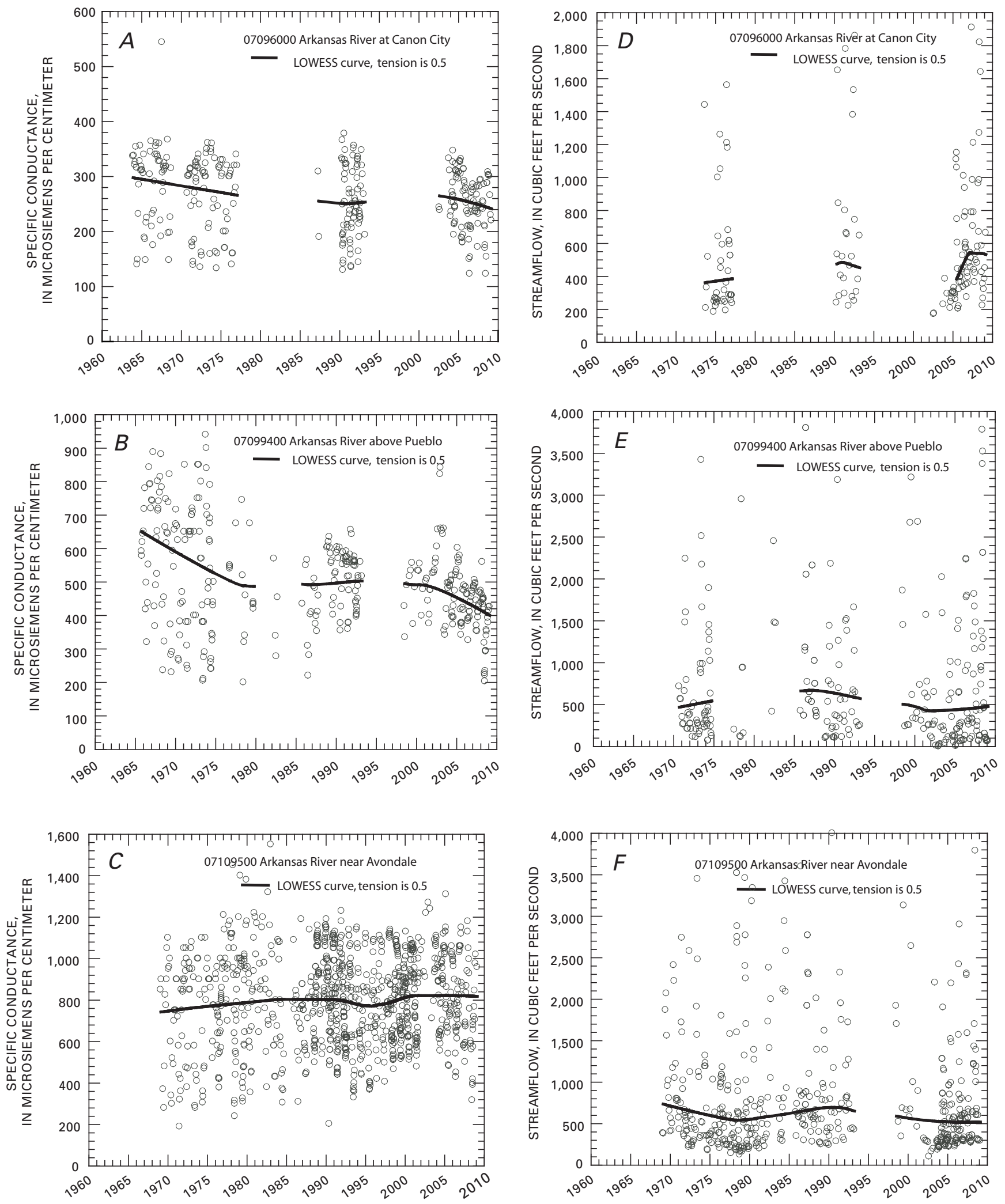
Publishing support provided by:

Denver Publishing Service Center

For more information concerning this publication, contact: Center Director, USGS Colorado Water Science Center Box 25046, Mail Stop 415

Denver, CO 80225

(303) 236-4882

Or visit the Colorado Water Science Center Web site at: http://co.water.usgs.gov/ 


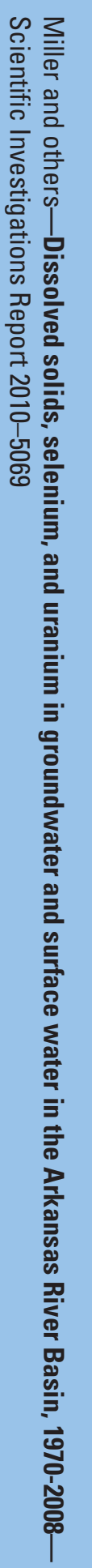

